\title{
Review \\ Effect of Cultivation Parameters on Fermentation and Hydrogen Production in the Phylum Thermotogae
}

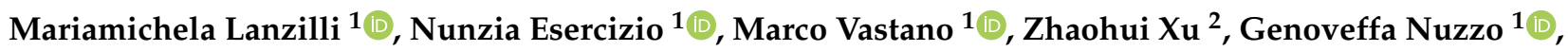 \\ Carmela Gallo $^{1} \mathbb{D}$, Emiliano Manzo ${ }^{1} \mathbb{D}$, Angelo Fontana ${ }^{1} \mathbb{D}$ and Giuliana d'Ippolito ${ }^{1, *}$ \\ 1 Istituto di Chimica Biomolecolare (ICB), CNR, Via Campi Flegrei 34, 80078 Pozzuoli, Napoli, Italy; \\ mariamichelalanzilli@gmail.com (M.L.); esercizionunzia@gmail.com (N.E.); \\ marco.vastano@gmail.com (M.V.); nuzzo.genoveffa@icb.cnr.it (G.N.); carmen.gallo@icb.cnr.it (C.G.); \\ emanzo@icb.cnr.it (E.M.); afontana@icb.cnr.it (A.F.) \\ 2 Department of Biological Sciences, Bowling Green State University, Bowling Green, OH 43403, USA; \\ zxu@bgsu.edu \\ * Correspondence: gdippolito@icb.cnr.it; Tel.: +39-081-8675096
}

check for updates

Citation: Lanzilli, M.; Esercizio, N.; Vastano, M.; Xu, Z.; Nuzzo, G.; Gallo, C.; Manzo, E.; Fontana, A.; d'Ippolito, G. Effect of Cultivation Parameters on Fermentation and Hydrogen Production in the Phylum Thermotogae. Int. J. Mol. Sci. 2021, 22, 341. https://doi.org/10.3390/ ijms22010341

Received: 12 October 2020 Accepted: 23 December 2020 Published: 30 December 2020

Publisher's Note: MDPI stays neutral with regard to jurisdictional clai$\mathrm{ms}$ in published maps and institutional affiliations.

Copyright: (C) 2020 by the authors. Licensee MDPI, Basel, Switzerland. This article is an open access article distributed under the terms and conditions of the Creative Commons Attribution (CC BY) license (https:// creativecommons.org/licenses/by/ $4.0 /)$.

\begin{abstract}
The phylum Thermotogae is composed of a single class (Thermotogae), 4 orders (Thermotogales, Kosmotogales, Petrotogales, Mesoaciditogales), 5 families (Thermatogaceae, Fervidobacteriaceae, Kosmotogaceae, Petrotogaceae, Mesoaciditogaceae), and 13 genera. They have been isolated from extremely hot environments whose characteristics are reflected in the metabolic and phenotypic properties of the Thermotogae species. The metabolic versatility of Thermotogae members leads to a pool of high valueadded products with application potentials in many industry fields. The low risk of contamination associated with their extreme culture conditions has made most species of the phylum attractive candidates in biotechnological processes. Almost all members of the phylum, especially those in the order Thermotogales, can produce bio-hydrogen from a variety of simple and complex sugars with yields close to the theoretical Thauer limit of $4 \mathrm{~mol} \mathrm{H}_{2} / \mathrm{mol}$ consumed glucose. Acetate, lactate, and L-alanine are the major organic end products. Thermotagae fermentation processes are influenced by various factors, such as hydrogen partial pressure, agitation, gas sparging, culture/headspace ratio, inoculum, $\mathrm{pH}$, temperature, nitrogen sources, sulfur sources, inorganic compounds, metal ions, etc. Optimization of these parameters will help to fully unleash the biotechnological potentials of Thermotogae and promote their applications in industry. This article gives an overview of how these operational parameters could impact Thermotogae fermentation in terms of sugar consumption, hydrogen yields, and organic acids production.
\end{abstract}

Keywords: anaerobic bacteria; hydrogen yields; fermentation rate; organic acids; nitrogen; carbon dioxide

\section{Introduction}

The phylum Thermotogae is comprised of thermophilic, hyperthermophilic, mesophilic, and thermo-acidophilic anaerobic bacteria that originated from geothermally heated environments (Table 1) [1,2]. Recent phylogenetic analyses based on gene markers/core genome inferences, comparative genomics, and whole-genome relatedness have led to a taxonomic revision of the phylum, with a single class (Thermotogae), 4 orders (Thermotogales, Kosmotogales, Petrotogales, Mesoaciditogales), 5 families (Thermatogaceae, Fervidobacteriaceae, Kosmotogaceae, Petrotogaceae, Mesoaciditogaceae), and 13 genera, i.e., Thermotoga (T.) [3], Pseudothermotoga (Pseudot.) [2,4], Fervidobacterium (F.) [5], Thermosipho (Ts.) [6], Kosmotoga (K.) [7], Mesotoga (Ms.) [8], Defluviitoga (D.) [9], Geotoga (G.) and Petrotoga (P.) [10], Marinitoga (Mn.) [11], Oceanotoga (O.) [12], Mesoaciditoga (M.) [13], and Athalassatoga (A.) (Table 1) [2,4,14]. Thermotogae are able to grow under mesophilic (Kosmotogales; Mesoaciditogales, Petrotogales) and thermophilic conditions (Thermotogales), but most species have optimal growth temperatures in the range of $45-80{ }^{\circ} \mathrm{C}$ (Table 1). They are Gram-negative 
bacteria, except for D. tunisiensis, which shows a positive result in Gram staining [9]. Apart from K. shengliensis, whose cells are in a coccoid form, Thermotogae cells are rod-shaped and encapsulated by a unique outer membrane, named "toga" $[1,8,15]$. Usually, the cells grow singly or in pairs, but it is also possible to observe chains surrounded by a unique toga [1,2]. Cell length is typically less than $20 \mu \mathrm{m}$, except for $F$. gondwanense and some members of the Petrotoga genus, whose cells can reach to $50 \mu \mathrm{m}$ long (Table 1) [2,10]. Almost all species grow at neutral $\mathrm{pH}$, and $\mathrm{NaCl}$ tolerances are high among Geotoga, Oceanotoga, and Petrotoga species (Table 1). Numerous studies have reported that members of the phylum can grow on both simple (e.g., glucose, galactose, fructose, lactose, maltose, mannose, sucrose) and complex carbohydrates (e.g., starch, glycogen, cellulose, keratin) (Table 1). Genes, transcriptional factors, and regulatory mechanisms driving the carbohydrates utilization have been identified for multiple members of the phylum [16-18]. ABC transporters for the uptake of a broad list of sugars have also been characterized [19-23].

All species of the phylum, except for Mesotoga spp., have tremendous potentials inbiotechnological production of $\mathrm{H}_{2}$, especially the order Thermotogales, as their hydrogen yields are close to the theoretical maximum value (Thauer limit) of $4 \mathrm{~mol} \mathrm{H}_{2} / \mathrm{mol}$ glucose $[1,4,24]$. Acetate, lactate, and L-alanine are the major organic products of the sugar fermentation [1]. Ms. prima and Ms. infera produce mainly/only acetate from sugar utilization without $\mathrm{H}_{2}$ formation [8,25-27]. Lactate is produced by T. maritima, T. neapolitana, and $M n$. camini in variable quantities depending on growth conditions [11,28-31]. Other significant products include ethanol (has been measured in Geotoga, Petrotoga, Kosmotoga, and Oceanotoga spp.); isovalerate, isobutyrate, and/or propionate (have been measured in $\mathrm{Mn}$. camini and K. olearia); L-glutamate, alpha-aminobutyrate, hydroxyphenyl-acetate, or phenylacetate (have been measured in F. pennavorans) [1,32] (Table 1). Among these fermentation end-products, lactic acid has been widely used in various industries such as food, cosmetic, pharmaceutical, and chemical industries, although its primary application is serving as the building block for the production of biodegradable polylactic acid (PLA) [33]. Ethanol is an important industrial commodity; it is used as a food additive and a renewable biofuel; it is also contained in many cosmetics, households, and sanitizer products [34]. Moreover, a plethora of thermostable enzymes, harbored by most of these bacteria, are valuable components for many industrial and biotechnological applications [17,35-44].

Hydrogen $\left(\mathrm{H}_{2}\right)$ is considered a green and sustainable alternative to traditional fossil fuels and is capable of mitigating greenhouse gas emissions. Using hydrogen in fuel cells or combustion engines produces heat and electricity with water as the only waste. As the current abiotic hydrogen production method is energy-consuming and still causes pollution, emphasis must be given to biological production of the energy from renewable sources $[45,46]$. Biological synthesis of $\mathrm{H}_{2}$ can use a wide range of organic substrates as feedstocks, including agro-industrial wastes and algal biomass, and may operate under various environmental conditions [1,46-54]. In addition, high temperatures help to improve the solubilization of substrates, reduce fermentation time, and lower contamination risks [55]. Although hydrogen production by Thermotoga species is considered one of the most challenging biological systems, no application using pure Thermotoga cultures has been reported at the industrial scale.

Releasing hydrogen is an efficient way to dissipate excessive reductants generated during the fermentative conversion of organic substrates. The process is generally referred to as dark fermentation (DF) and is typically influenced by environmental conditions such as $\mathrm{pH}$, cell growth rate, and hydrogen partial pressure [24,56,57].

According to the classical model of dark fermentation, theoretically up to $4 \mathrm{~mol}$ of hydrogen may be produced from each mole of glucose, which is converted to acetate and $\mathrm{CO}_{2}$ (Thaeur limit Figure 1) [24]. When hydrogen accumulates, pyruvate is diverted away from acetate production. In this case, excessive NADH from glycolysis is not used in the energetically favorable manner to synthesize acetate and $\mathrm{H}_{2}$ but dissipated via synthesizing other metabolic products such as lactic acid, L-alanine, ethanol, butyrate, and valerate (Figure 1) [24]. Synthesis of hydrogen in Thermotogae species is performed 
by the heterotrimeric [FeFe]-hydrogenase, an electron-bifurcating enzyme that couples the endergonic reduction of $\mathrm{H}^{+}$to hydrogen by NADH to the exergonic reduction of $\mathrm{H}^{+}$ to hydrogen by reduced ferredoxin (Figure 1) [58]. Because the hydrogenase uses both $\mathrm{NADH}$ and reduced ferredoxin as electron donors, hydrogen yield is influenced by factors that affect both reductants.

The value of these bacteria in biotechnological processes is rising sharply since the discovery of the bifurcating hydrogenase and will probably be enhanced with a full elucidation of the molecular and biochemical properties of the processes. Despite decades of efforts in the development of genetic tools to engineer these species, only a few of thermostable selectable markers and genetic modifications with low stability are reported, which makes it still difficult to perform genetic modifications of these organisms [59-61]. However, these difficulties could be offset by their well-known susceptibility to mutations under environmental pressures [62,63].

In recent years, many researchers have been focusing on the optimization of fermentation performance towards the production of hydrogen and other target end-products $[30,43,64-71]$.

Anaerobic fermentation in Thermotogae depends on many cultivation parameters such as hydrogen partial pressure, agitation, gas sparging, culture/headspace ratio, inoculum, $\mathrm{pH}$, temperature, nitrogen sources, sulfur sources, inorganic compounds, and metal ions. The effect of each factor on $\mathrm{H}_{2}$ yield, sugar consumption rate, and formation of biotechnologically interesting end-products are discussed here. Main data are also summarized in extensive tables, citing the most important studies, with the information on their cultivation systems (e.g., reactor type, incubation periods, batch vs. continuous modality). 


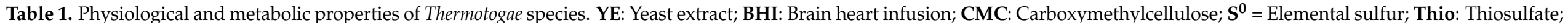

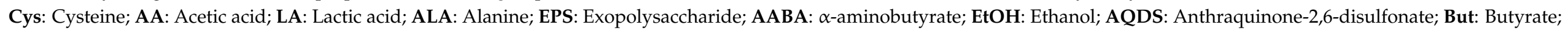

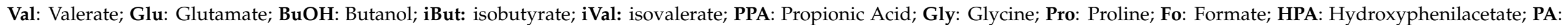

Phenylacetate; 3-IAA: Indole-3-acetate; 2-MeBu: 2-Methylbutyrate.

\begin{tabular}{|c|c|c|c|c|c|c|c|c|c|c|}
\hline Genus & Species & Isolation & $\begin{array}{l}\text { Temp. Range/ } \\
\text { Optimal }\left({ }^{\circ} \mathrm{C}\right)\end{array}$ & $\begin{array}{c}\mathrm{pH} \\
\text { Range/ } \\
\text { Optimal }\end{array}$ & $\begin{array}{c}\text { Cell } \\
\text { Dimension } \\
(\text { Long by Wide) } \\
(\mu \mathrm{m})\end{array}$ & Growth Substrates & $\begin{array}{l}\text { NaCl Range/ } \\
\text { Optimal } \\
(\%)\end{array}$ & $\begin{array}{l}\text { Electron } \\
\text { Acceptor }\end{array}$ & $\begin{array}{c}\text { End } \\
\text { Products }\end{array}$ & Ref. \\
\hline \multirow{6}{*}{ Thermotoga } & $\begin{array}{l}\text { Thermotoga } \\
\text { petrophila }\end{array}$ & $\begin{array}{l}\text { Oil } \\
\text { reservoir, } \\
\text { Japan }\end{array}$ & $\begin{array}{c}47-88 / \\
80\end{array}$ & $\begin{array}{l}5.2-9.0 / \\
7.0\end{array}$ & $\begin{array}{c}2.0-7.0 \\
\text { by } 0.7-1.0\end{array}$ & $\begin{array}{l}\text { YE, peptone, glucose, fructose, ribose, } \\
\text { arabinose, sucrose, lactose, maltose, } \\
\text { starch, cellulose }\end{array}$ & $\begin{array}{l}0.1-5.5 / \\
1.0\end{array}$ & $\begin{array}{l}S^{0} ; \\
\text { Thio }\end{array}$ & $\begin{array}{l}\mathrm{AA}, \mathrm{LA} \\
\mathrm{CO}_{2}, \mathrm{H}_{2}\end{array}$ & [72] \\
\hline & $\begin{array}{l}\text { Thermotoga } \\
\text { naphthophila }\end{array}$ & $\begin{array}{l}\text { Oil } \\
\text { reservoir, } \\
\text { Japan }\end{array}$ & $\begin{array}{l}48-86 / \\
80\end{array}$ & $\begin{array}{l}5.4-9.0 / \\
7.0\end{array}$ & $\begin{array}{c}2.0-7.0 \\
\text { by } 0.8-1.2\end{array}$ & $\begin{array}{l}\text { YE, peptone, glucose, galactose, fructose, } \\
\text { mannitol, ribose, arabinose, sucrose, } \\
\text { lactose, maltose, starch }\end{array}$ & $\begin{array}{l}0.1-6.0 / \\
1.0\end{array}$ & $\begin{array}{l}S^{0} ; \\
\text { Thio }\end{array}$ & $\begin{array}{l}\mathrm{AA}, \mathrm{LA} \\
\mathrm{CO}_{2}, \mathrm{H}_{2}\end{array}$ & [72] \\
\hline & $\begin{array}{l}\text { Thermotoga } \\
\text { maritima }\end{array}$ & $\begin{array}{l}\text { Geotermal } \\
\text { vent }\end{array}$ & $\begin{array}{c}55-90 / \\
80\end{array}$ & $\begin{array}{l}5.5-9.0 / \\
6.5\end{array}$ & $\begin{array}{l}1.5-11.0 \\
\text { by } 0.6\end{array}$ & $\begin{array}{l}\text { ribose, xylose, glucose, sucrose, maltose, } \\
\text { lactose, galactose, starch, glycogen }\end{array}$ & $\begin{array}{l}0.2-3.8 / \\
2.7\end{array}$ & $\begin{array}{l}\text { Fe (III) } \\
\text { S } \\
\text { Thio }\end{array}$ & $\begin{array}{l}\text { AA, LA, } \\
\mathrm{CO}_{2}, \mathrm{H}_{2} \\
\text { ALA, EPS, } \\
\text { AABA }\end{array}$ & [3] \\
\hline & $\begin{array}{l}\text { Thermotoga } \\
\text { profunda }\end{array}$ & $\begin{array}{c}\text { Hot spring, } \\
\text { Japan }\end{array}$ & $\begin{array}{c}50-72 / \\
60\end{array}$ & $\begin{array}{l}6.0-8.6 / \\
7.4\end{array}$ & $\begin{array}{l}0.8-2.1 \\
\text { by } 0.4\end{array}$ & $\begin{array}{l}\text { glucose, trehalose, cellobiose, arabinose, } \\
\text { xylose, ribose, pyruvate }\end{array}$ & n. $d$ & $\begin{array}{l}\text { S } \\
\text { Thio }\end{array}$ & n. d & [73] \\
\hline & $\begin{array}{l}\text { Thermotoga } \\
\text { caldifontis }\end{array}$ & $\begin{array}{c}\text { Hot spring, } \\
\text { Japan }\end{array}$ & $\begin{array}{c}55-85 / \\
70\end{array}$ & $\begin{array}{l}6.0-8.6 / \\
7.4\end{array}$ & $\begin{array}{l}1.2-3.5 \\
\text { by } 0.5\end{array}$ & $\begin{array}{l}\text { glucose, maltose, trehalose, cellobiose, } \\
\text { arabinose, xylose, ribose, pyruvate, starch }\end{array}$ & n. d & Thio & n. d & [73] \\
\hline & $\begin{array}{l}\text { Thermotoga } \\
\text { neapolitana }\end{array}$ & $\begin{array}{l}\text { Submarine } \\
\text { thermal } \\
\text { vent }\end{array}$ & $\begin{array}{l}55-95 / \\
77\end{array}$ & $\begin{array}{l}6.0-9.0 / \\
7.5\end{array}$ & $\begin{array}{l}1.5-11.0 \\
\text { by } 0.6\end{array}$ & $\begin{array}{l}\text { fructose, fucose, galactose, mannose, } \\
\text { rhamnose, pyruvate, glucosamine, } \\
\text { lactulose, turanose, glycerol, dextrin, } \\
\text { ribose, xylose, glucose, sucrose, maltose, } \\
\text { lactose, starch, glycogen }\end{array}$ & $\begin{array}{l}0.2-6.0 / \\
2.0\end{array}$ & $S^{0}$ & $\begin{array}{l}\mathrm{AA}, \mathrm{ALA} \\
\mathrm{CO}_{2}, \mathrm{H}_{2}\end{array}$ & [74] \\
\hline \multirow{3}{*}{ Pseudothermotoga } & $\begin{array}{l}\text { Pseudothermotoga } \\
\text { lettingae }\end{array}$ & $\begin{array}{l}\text { Thermophilic } \\
\text { bioreactor }\end{array}$ & $\begin{array}{l}50-75 / \\
65\end{array}$ & $\begin{array}{l}6.0-8.5 / \\
7.0\end{array}$ & $\begin{array}{l}2.0-3.0 \\
\text { by } 0.5-1.0\end{array}$ & glucose, $\mathrm{EtOH}$, acetate, formate & $\begin{array}{l}0.0-2.8 / \\
1.0\end{array}$ & $\begin{array}{l}\text { S0; Thio; } \\
\text { AQDS; } \\
\text { Fe(III) }\end{array}$ & $\begin{array}{c}\text { AA, ALA, } \\
\text { LA, } \\
\text { EtOH, AA, } \\
\text { BA, } \mathrm{CO}_{2}, \mathrm{H}_{2}\end{array}$ & [75] \\
\hline & $\begin{array}{l}\text { Pseudothermotoga } \\
\text { elfii }\end{array}$ & Oil reservoir & $\begin{array}{c}50-72 / \\
66\end{array}$ & $\begin{array}{l}5.5-7.5 / \\
7.5\end{array}$ & $\begin{array}{l}2.0-3.0 \\
\text { by } 0.5-1.0\end{array}$ & $\begin{array}{l}\text { glucose, arabinose, fructose, lactose, } \\
\text { maltose, mannose, ribose, sucrose, xylose }\end{array}$ & $\begin{array}{l}0.0-2.8 / \\
1.0\end{array}$ & Thio & $\begin{array}{l}\mathrm{AA}, \mathrm{CO}_{2} \\
\mathrm{H}_{2}\end{array}$ & {$[76]$} \\
\hline & $\begin{array}{l}\text { Pseudothermotoga } \\
\text { hypogea }\end{array}$ & $\begin{array}{l}\text { Oil } \\
\text { reservoir, } \\
\text { Africa }\end{array}$ & $\begin{array}{c}56-90 / \\
70\end{array}$ & $\begin{array}{l}6.1-9.1 / \\
7.3-7.4\end{array}$ & $\begin{array}{c}2.0-3.0 \\
\text { by } 0.5-1.0\end{array}$ & $\begin{array}{l}\text { fructose, galactose, glucose, lactose, } \\
\text { maltose, mannose, sucrose, xylose, xylan }\end{array}$ & $\begin{array}{l}0.0-1.5 / \\
0.2\end{array}$ & Thio & $\begin{array}{l}\mathrm{AA}, \mathrm{ALA}, \\
\mathrm{CO}_{2}, \mathrm{H}_{2} \\
\text { EtOH }\end{array}$ & [77] \\
\hline \multirow{2}{*}{ Pseudothermotoga } & $\begin{array}{l}\text { Pseudothermotoga } \\
\text { subterranea }\end{array}$ & $\begin{array}{l}\text { Oil } \\
\text { reservoir, } \\
\text { Paris }\end{array}$ & $\begin{array}{c}50-75 / \\
70\end{array}$ & $\begin{array}{l}6.0-8.5 / \\
7.0\end{array}$ & $\begin{array}{l}3.0-10.0 \\
\text { by } 0.5\end{array}$ & YE, peptone, tryptone, casein & $\begin{array}{c}0.0-2.4 / \\
1.2\end{array}$ & $\begin{array}{l}\text { Cys, } \\
\text { Thio }\end{array}$ & n.d. & [78] \\
\hline & $\begin{array}{l}\text { Pseudothermotoga } \\
\text { thermarum }\end{array}$ & $\begin{array}{l}\text { Hot spring, } \\
\text { Africa }\end{array}$ & $\begin{array}{c}55-84 / \\
70\end{array}$ & $\begin{array}{l}6.0-9.0 / \\
7.0\end{array}$ & $\begin{array}{l}1.5-11.0 \\
\text { by } 0.6\end{array}$ & starch, glucose, maltose & $\begin{array}{c}0.2-0.5 / \\
0.35\end{array}$ & $S^{0}$ & n.d. & [6] \\
\hline
\end{tabular}


Table 1. Cont.

\begin{tabular}{|c|c|c|c|c|c|c|c|c|c|c|}
\hline Genus & Species & Isolation & $\begin{array}{l}\text { Temp. Range/ } \\
\text { Optimal }\left({ }^{\circ} \mathrm{C}\right)\end{array}$ & $\begin{array}{c}\mathrm{pH} \\
\text { Range/ } \\
\text { Optimal }\end{array}$ & $\begin{array}{c}\text { Cell } \\
\text { Dimension } \\
\text { (Long by Wide) } \\
(\mu \mathrm{m})\end{array}$ & Growth Substrates & $\begin{array}{c}\text { NaCl Range/ } \\
\text { Optimal } \\
(\%)\end{array}$ & $\begin{array}{l}\text { Electron } \\
\text { Acceptor }\end{array}$ & $\begin{array}{l}\text { End } \\
\text { Products }\end{array}$ & Ref. \\
\hline \multirow{6}{*}{ Fervidobacterium } & $\begin{array}{l}\text { Fervidobacterium } \\
\quad \text { nodosum }\end{array}$ & $\begin{array}{l}\text { Hot spring, } \\
\text { New } \\
\text { Zealand }\end{array}$ & $\begin{array}{l}40-80 / \\
65-70\end{array}$ & $\begin{array}{l}6.0-8.0 / \\
7.0\end{array}$ & $\begin{array}{l}1.0-2.5 \\
\text { by } 0.5-0.55\end{array}$ & glucose, sucrose, starch and lactose & n.d. $/<1.0$ & $S^{0}$ & $\begin{array}{l}\mathrm{AA}, \mathrm{LA}, \\
\mathrm{CO}_{2}, \mathrm{H}_{2} \\
\text { EtOH, But, } \\
\quad \text { Val }\end{array}$ & [5] \\
\hline & $\begin{array}{l}\text { Fervidobacterium } \\
\text { pennavorans }\end{array}$ & $\begin{array}{l}\text { Hot spring, } \\
\text { Portugal }\end{array}$ & $\begin{array}{l}50-80 / \\
70\end{array}$ & $\begin{array}{l}5.5-8.0 / \\
6.5\end{array}$ & $\begin{array}{l}2.0-20.0 \\
\text { by } 0.5\end{array}$ & $\begin{array}{l}\text { cellobiose, starch, glycogen, pullulan, } \\
\text { glucose, fructose, maltose, xylose, } \\
\text { native feathers }\end{array}$ & $\begin{array}{l}0.0-4.0 / \\
0.4\end{array}$ & $\begin{array}{l}S^{0} \\
\text { Thio }\end{array}$ & $\begin{array}{l}\mathrm{AA}, \mathrm{CO}_{2} \\
\text { ALA, Glu, } \\
\text { EtOH, But, } \\
\mathrm{H}_{2}, \mathrm{BuOH}\end{array}$ & [79] \\
\hline & $\begin{array}{l}\text { Fervidobacterium } \\
\text { islandicum }\end{array}$ & $\begin{array}{l}\text { Icelandic } \\
\text { Hot spring }\end{array}$ & $\begin{array}{l}50-80 / \\
65\end{array}$ & $\begin{array}{l}6.0-8.0 / \\
7.2\end{array}$ & $\begin{array}{l}1.0-4.0 \\
\text { by } 0.6\end{array}$ & $\begin{array}{l}\text { pyruvate, ribose, glucose, maltose, } \\
\text { raffinose, starch, cellulose }\end{array}$ & $\begin{array}{c}0.0-1.0 / \\
0.2\end{array}$ & $\begin{array}{l}\mathrm{S}^{0} \\
\text { Thio }\end{array}$ & $\begin{array}{l}\text { LA, } \mathrm{AA}, \mathrm{H}_{2} \\
\text { EtOH, CO } \\
\text { iBut, iVal }\end{array}$ & [80] \\
\hline & $\begin{array}{l}\text { Fervidobacterium } \\
\quad \text { riparium }\end{array}$ & $\begin{array}{l}\text { Hot spring, } \\
\text { Russia }\end{array}$ & $\begin{array}{l}46-80 / \\
65\end{array}$ & $\begin{array}{l}5.7-7.9 / \\
7.8\end{array}$ & $\begin{array}{l}1.0-3.0 \\
\text { by } 0.4-0.5\end{array}$ & $\begin{array}{l}\text { peptone, YE, pyruvate, glucose, xylose, } \\
\text { fructose, maltose, sucrose, cellobiose, } \\
\text { starch, xylan, CMC, cellulose, filter paper }\end{array}$ & $\begin{array}{l}0.0-1.0 / \\
0.0\end{array}$ & $S^{0}$ & $\begin{array}{l}\mathrm{H}_{2}, \mathrm{AA} \\
\mathrm{CO}_{2}, \text { PPA, } \\
\text { iBut, But }\end{array}$ & [81] \\
\hline & $\begin{array}{l}\text { Fervidobacterium } \\
\text { gondwanense }\end{array}$ & $\begin{array}{l}\text { Hot spring, } \\
\text { Australia }\end{array}$ & $\begin{array}{l}45-80 / \\
65-68\end{array}$ & $\begin{array}{l}5.5-8.5 / \\
7.0\end{array}$ & $\begin{array}{l}4.0-40.0 \\
\text { by } 0.5-0.6\end{array}$ & $\begin{array}{c}\text { cellobiose, amylopectin, maltose, starch, } \\
\text { dextrin, xylose, glucose, pyruvate, } \\
\text { lactose, fructose, mannose, CMC, } \\
\text { galactose }\end{array}$ & $\begin{array}{l}0.0-0.6 / \\
0.1\end{array}$ & $S^{0}$ & $\begin{array}{l}\mathrm{EtOH}, \mathrm{AA} \\
\mathrm{LA}, \mathrm{CO}_{2}, \mathrm{H}_{2}\end{array}$ & [82] \\
\hline & $\begin{array}{l}\text { Fervidobacterium } \\
\text { changbaicum }\end{array}$ & $\begin{array}{l}\text { Hot spring, } \\
\text { China }\end{array}$ & $\begin{array}{l}55-90 / \\
75-80\end{array}$ & $\begin{array}{l}6.3-8.5 / \\
7.5\end{array}$ & $\begin{array}{l}1.0-8.0 \\
\text { by } 0.5-0.6\end{array}$ & $\begin{array}{c}\text { glucose, lactose, fructose, sucrose, } \\
\text { maltose, starch, sorbitol, cellobiose, } \\
\text { trehalose, } \\
\text { galactose, melibiose, pyruvate, glycerin }\end{array}$ & $\begin{array}{l}0.0-1.0 / \\
0.0\end{array}$ & $S^{0}$ & n.d. & [84] \\
\hline \multirow{3}{*}{ Thermosipho } & $\begin{array}{l}\text { Thermosipho } \\
\text { africanus }\end{array}$ & $\begin{array}{l}\text { Hot spring, } \\
\text { Africa }\end{array}$ & $\begin{array}{l}53-77 / \\
75\end{array}$ & $\begin{array}{l}6.0-8.0 / \\
7.2\end{array}$ & $\begin{array}{l}3.0-4.0 \\
\text { by } 0.5\end{array}$ & $\begin{array}{l}\text { glucose, ribose, maltose, starch, } \\
\text { galactose, fructose, sucrose }\end{array}$ & $0.11-3.6$ & $\begin{array}{l}\mathrm{S}^{0} \\
\text { Thio }\end{array}$ & $\begin{array}{c}\mathrm{AA}, \mathrm{H}_{2} \\
\mathrm{CO}_{2,} \\
\text { EtOH, LA }\end{array}$ & [85] \\
\hline & $\begin{array}{l}\text { Thermosipho } \\
\text { japonicus }\end{array}$ & $\begin{array}{l}\text { Hydrothermal } \\
\text { vent, Japan }\end{array}$ & $\begin{array}{l}45-80 / \\
72\end{array}$ & $\begin{array}{l}5.3-9.3 / \\
7.2-7.6\end{array}$ & $\begin{array}{l}3.0-4.0 \\
\text { by } 0.5\end{array}$ & $\begin{array}{l}\text { YE, peptone, and tryptone, maltose, } \\
\text { glucose, galactose, starch, sacharose, } \\
\text { ribose, casein }\end{array}$ & $\begin{array}{l}0.7-7.9 / \\
4.0\end{array}$ & $\begin{array}{l}S^{0} ; \\
\text { Thio }\end{array}$ & n.d. & [86] \\
\hline & $\begin{array}{l}\text { Thermosipho } \\
\text { geolei }\end{array}$ & $\begin{array}{l}\text { Oil } \\
\text { reservoir, } \\
\text { Russia }\end{array}$ & $\begin{array}{l}45-75 / \\
70\end{array}$ & $\begin{array}{l}6.0-9.4 / \\
7.5\end{array}$ & $\begin{array}{c}2.0-3.0 \\
\text { by } 0.4-0.6\end{array}$ & Glucose, peptone, beef extract, YE & $\begin{array}{l}0.5-7.0 / \\
2.0-3.0\end{array}$ & $S^{0}$ & $\begin{array}{l}\mathrm{H}_{2}, \mathrm{AA}, \\
\mathrm{ALA}, \mathrm{CO}_{2} \\
\quad \text { iVal }\end{array}$ & [87] \\
\hline \multirow[t]{2}{*}{ Thermosipho } & $\begin{array}{l}\text { Thermosipho } \\
\text { affectus }\end{array}$ & $\begin{array}{l}\text { Hydrothermal } \\
\text { vent, } \\
\text { Atlantic } \\
\text { Ocean }\end{array}$ & $\begin{array}{l}37-75 / \\
70\end{array}$ & $\begin{array}{l}5.6-8.2 / \\
\quad 6.6\end{array}$ & $\begin{array}{c}1.2-6.0 \\
\text { by } 0.4-0.9\end{array}$ & $\begin{array}{l}\text { YE, beef extract, glucose, maltose, } \\
\text { sucrose, starch, dextrin, CMC, cellulose }\end{array}$ & $\begin{array}{l}1.0-5.5 / \\
2.0\end{array}$ & $S^{0}$ & $\begin{array}{l}\mathrm{AA}, \mathrm{H}_{2} \\
\mathrm{CO}_{2}, \mathrm{EtOH}\end{array}$ & [88] \\
\hline & $\begin{array}{l}\text { Thermosipho } \\
\text { globiformans }\end{array}$ & $\begin{array}{l}\text { Hydrothermal } \\
\text { vent }\end{array}$ & $\begin{array}{l}40-75 / \\
68\end{array}$ & $\begin{array}{l}5.0-8.2 / \\
6.8\end{array}$ & $\begin{array}{l}2.0-4.0 \\
\text { by } 0.5\end{array}$ & YE, tryptone, starch & $\begin{array}{l}0.2-5.2 / \\
2.5\end{array}$ & $\begin{array}{c}\mathrm{S}^{0} \\
\mathrm{Fe}_{2} \mathrm{O}_{3}\end{array}$ & n.d. & [89] \\
\hline
\end{tabular}


Table 1. Cont

\begin{tabular}{|c|c|c|c|c|c|c|c|c|c|c|}
\hline Genus & Species & Isolation & $\begin{array}{l}\text { Temp. Range/ } \\
\text { Optimal }\left({ }^{\circ} \mathrm{C}\right)\end{array}$ & $\begin{array}{c}\mathrm{pH} \\
\text { Range/ } \\
\text { Optimal }\end{array}$ & $\begin{array}{c}\text { Cell } \\
\text { Dimension } \\
\text { (Long by Wide) } \\
(\mu \mathrm{m})\end{array}$ & Growth Substrates & $\begin{array}{c}\text { NaCl Range/ } \\
\text { Optimal } \\
(\%)\end{array}$ & $\begin{array}{l}\text { Electron } \\
\text { Acceptor }\end{array}$ & $\begin{array}{l}\text { End } \\
\text { Products }\end{array}$ & Ref \\
\hline & $\begin{array}{l}\text { Thermosipho } \\
\text { melanesiensis }\end{array}$ & $\begin{array}{l}\text { Hydrothermal } \\
\text { vent, } \\
\text { Pacific } \\
\text { Ocean } \\
\end{array}$ & $\begin{array}{l}50-75 / \\
70\end{array}$ & $\begin{array}{l}4.5-8.5 / \\
6.5-7.5\end{array}$ & $\begin{array}{l}1.0-3.5 \\
\text { by } 0.4-0.6\end{array}$ & $\begin{array}{l}\text { BHI, malt extract, tryptone, sucrose, } \\
\text { starch, glucose, maltose, lactose, } \\
\text { cellobiose, galactose }\end{array}$ & $\begin{array}{c}1.0-6.0 / \\
3.0\end{array}$ & $S^{0}$ & $\begin{array}{l}\mathrm{H}_{2}, \mathrm{AA} \\
\mathrm{ALA}, \mathrm{CO}_{2}\end{array}$ & {$[90]$} \\
\hline & $\begin{array}{l}\text { Thermosipho } \\
\text { activus }\end{array}$ & $\begin{array}{l}\text { Riftia } \\
\text { sheath, } \\
\text { Guaymas } \\
\text { Basin }\end{array}$ & $\begin{array}{l}44-75 / \\
65\end{array}$ & $\begin{array}{l}5.5-8.0 / \\
6.0\end{array}$ & $\begin{array}{l}1.5-10.0 \\
\text { by } 0.3-0.8\end{array}$ & $\begin{array}{l}\text { glucose, maltose, cellobiose, cellulose, } \\
\text { filter paper, chitin, xylan, pectin, xanthan } \\
\text { gum, YE, beef extract, tryptone, casein, } \\
\text { keratin, arabinose, xylose, gelatin }\end{array}$ & $\begin{array}{l}0.3-6.0 / \\
2.5\end{array}$ & $\begin{array}{l}S^{0} \\
\mathrm{Fe}(\mathrm{III})\end{array}$ & $\begin{array}{l}\mathrm{AA}, \mathrm{H}_{2} \\
\mathrm{CO}_{2}\end{array}$ & [91] \\
\hline & $\begin{array}{l}\text { Thermosipho } \\
\text { atlanticus }\end{array}$ & $\begin{array}{l}\text { Hydrothermal } \\
\text { vent, } \\
\text { Atlantic } \\
\text { Ocean }\end{array}$ & $\begin{array}{l}45-80 / \\
65\end{array}$ & $\begin{array}{l}5.0-9.0 / \\
6.0\end{array}$ & $\begin{array}{c}1.0-2.6 \\
\text { by } 0.2-0.6\end{array}$ & $\begin{array}{c}\text { cellobiose, xylose, starch, LA, maltose, } \\
\text { mannose, trehalose, lactose, arabinose, } \\
\text { galactose, mannitol, peptone, } \\
\text { casamino acids, gelatin, BHI, YE, glucose }\end{array}$ & $\begin{array}{l}1.5-4.6 / \\
2.3\end{array}$ & $\begin{array}{l}S^{0}, \\
\text { Thio, } \\
\text { Cys }\end{array}$ & $\begin{array}{l}\text { AA, iVal, } \\
\mathrm{H}_{2} \text {, Gly, } \\
\text { ALA, Pro }\end{array}$ & [92] \\
\hline \multirow{2}{*}{ Geotoga } & $\begin{array}{c}\text { Geotoga } \\
\text { subterranea }\end{array}$ & $\begin{array}{l}\text { Oilfields, } \\
\text { USA }\end{array}$ & $\begin{array}{c}30-60 / \\
45\end{array}$ & $\begin{array}{l}5.5-9.0 / \\
6.5\end{array}$ & $\begin{array}{l}4.0-7.5 \\
\text { by } 0.5\end{array}$ & $\begin{array}{l}\text { mannose, starch, maltodextrins, glucose, } \\
\text { lactose, sucrose, galactose, maltose }\end{array}$ & $\begin{array}{c}0.5-10 / \\
4.0\end{array}$ & $S^{0}$ & $\begin{array}{l}\mathrm{H}_{2}, \mathrm{CO}_{2} \\
\mathrm{AA}, \text { EtOH }\end{array}$ & {$[10]$} \\
\hline & $\begin{array}{l}\text { Geotoga } \\
\text { petraea }\end{array}$ & $\begin{array}{l}\text { Oilfields, } \\
\text { USA }\end{array}$ & $\begin{array}{c}30-55 / \\
50\end{array}$ & $\begin{array}{l}5.5-9.0 / \\
6.5\end{array}$ & $\begin{array}{l}3.0-20.0 \\
\text { by } 0.6\end{array}$ & $\begin{array}{l}\text { mannose, starch, maltodextrins, glucose, } \\
\text { lactose, sucrose, galactose, maltose }\end{array}$ & $\begin{array}{l}0.5-10 / \\
3.0\end{array}$ & $S^{0}$ & $\begin{array}{l}\mathrm{H}_{2}, \mathrm{CO}_{2} \\
\mathrm{AA}, \mathrm{EtOH}\end{array}$ & {$[10]$} \\
\hline \multirow{3}{*}{ Petrotoga } & $\begin{array}{l}\text { Petrotoga } \\
\text { miotherma }\end{array}$ & $\begin{array}{l}\text { Oilfields, } \\
\text { USA }\end{array}$ & $\begin{array}{c}35-65 / \\
55\end{array}$ & $\begin{array}{c}5.5-9.0 / \\
6.5\end{array}$ & $\begin{array}{l}2.0-7.5 \\
\text { by } 0.6\end{array}$ & $\begin{array}{l}\text { mannose, starch, maltodextrins, glucose, } \\
\text { lactose, sucrose, galactose, maltose, } \\
\text { maltodexstrins, xylose }\end{array}$ & $\begin{array}{l}0.5-10 / \\
2.0\end{array}$ & $S^{0}$ & $\begin{array}{c}\mathrm{H}_{2}, \mathrm{CO}_{2} \\
\mathrm{AA}, \mathrm{EtOH}\end{array}$ & {$[10]$} \\
\hline & $\begin{array}{l}\text { Petrotoga } \\
\text { olearia }\end{array}$ & $\begin{array}{l}\text { Oil } \\
\text { reservoir, } \\
\text { Russia }\end{array}$ & $\begin{array}{c}37-60 / \\
55\end{array}$ & $\begin{array}{c}6.5-8.5 / \\
7.5\end{array}$ & $\begin{array}{c}0.9-2.5 \\
\text { by } 0.3-0.6\end{array}$ & $\begin{array}{l}\text { arabinose, xylose, cellobiose, dextrin, } \\
\text { sucrose, glucose, fructose, maltose, ribose, } \\
\text { trehalose, xylan, pyruvate, peptone, } \\
\text { starch }\end{array}$ & $\begin{array}{c}0.5-8.0 / \\
2.0\end{array}$ & $S^{0}$ & $\begin{array}{l}\mathrm{H}_{2}, \mathrm{AA}, \mathrm{LA}, \\
\text { ALA, EtOH }\end{array}$ & [93] \\
\hline & $\begin{array}{l}\text { Petrotoga } \\
\text { sibirica }\end{array}$ & $\begin{array}{l}\text { Oil } \\
\text { reservoir, } \\
\text { Russia }\end{array}$ & $\begin{array}{c}37-55 / \\
55\end{array}$ & $\begin{array}{c}6.5-9.4 / \\
8.0\end{array}$ & $\begin{array}{c}0.9-2.5 \\
\text { by } 0.3-0.6\end{array}$ & $\begin{array}{c}\text { sucrose, glucose, fructose, maltose, ribose, } \\
\text { trehalose, xylan, pyruvate, peptone, } \\
\text { galactose }\end{array}$ & $\begin{array}{c}0.5-7.0 / \\
1.0\end{array}$ & $S^{0}$ & $\begin{array}{l}\mathrm{H}_{2}, \mathrm{AA}, \mathrm{LA}, \\
\text { ALA, EtOH }\end{array}$ & [93] \\
\hline \multirow[t]{2}{*}{ Petrotoga } & $\begin{array}{c}\text { Petrotoga } \\
\text { mobilis }\end{array}$ & $\begin{array}{c}\text { Oilfield, } \\
\text { North Sea }\end{array}$ & $\begin{array}{l}40-65 / \\
58-60\end{array}$ & $\begin{array}{c}5.5-8.5 / \\
6.5-7.0\end{array}$ & $\begin{array}{c}1.0-50.0 \\
\text { by } 0.5-1.5\end{array}$ & $\begin{array}{c}\text { starch, xylan, maltodextrin, maltose, } \\
\text { cellobiose, sucrose, lactose, glucose, } \\
\text { galactose, fructose, arabinose, xylose, } \\
\text { ribose, rhamnose }\end{array}$ & $\begin{array}{l}0.5-9.0 / \\
3.0-4.0\end{array}$ & $\begin{array}{l}S^{0} \\
\text { Thio }\end{array}$ & $\begin{array}{l}\mathrm{H}_{2}, \mathrm{CO}_{2} \\
\mathrm{AA}, \mathrm{EtOH}\end{array}$ & {$[94]$} \\
\hline & $\begin{array}{l}\text { Petrotoga } \\
\text { halophila }\end{array}$ & $\begin{array}{l}\text { Offshore oil, } \\
\text { Africa }\end{array}$ & $\begin{array}{c}45-65 / \\
60\end{array}$ & $\begin{array}{c}5.6-7.8 / \\
6.7-7.2\end{array}$ & $\begin{array}{c}2.0-45.0 \\
\text { by } 0.5-0.7\end{array}$ & $\begin{array}{l}\text { arabinose, cellobiose, fructose, galactose, } \\
\text { glucose, lactose, maltose, rhamnose, } \\
\text { ribose, starch, sucrose, xylose, xylan, } \\
\text { pyruvate }\end{array}$ & $\begin{array}{l}0.5-9.0 / \\
4.0-6.0\end{array}$ & $\mathrm{~S}^{0}$ & $\begin{array}{l}\text { AA, LA, } \\
\mathrm{ALA}_{,} \mathrm{H}_{2} \\
\mathrm{CO}_{2}\end{array}$ & [95] \\
\hline
\end{tabular}


Table 1. Cont.

\begin{tabular}{|c|c|c|c|c|c|c|c|c|c|c|}
\hline Genus & Species & Isolation & $\begin{array}{l}\text { Temp. Range/ } \\
\text { Optimal }\left({ }^{\circ} \mathrm{C}\right)\end{array}$ & $\begin{array}{c}\text { pH } \\
\text { Range/ } \\
\text { Optimal }\end{array}$ & $\begin{array}{c}\text { Cell } \\
\text { Dimension } \\
(\text { Long by Wide) } \\
(\mu \mathrm{m})\end{array}$ & Growth Substrates & $\begin{array}{c}\text { NaCl Range/ } \\
\text { Optimal }\end{array}$ & $\begin{array}{l}\text { Electron } \\
\text { Acceptor }\end{array}$ & $\begin{array}{c}\text { End } \\
\text { Products }\end{array}$ & Ref. \\
\hline & $\begin{array}{l}\text { Petrotoga } \\
\text { mexicana }\end{array}$ & $\begin{array}{l}\text { Offshore oil, } \\
\text { Africa }\end{array}$ & $\begin{array}{c}25-65 / \\
55\end{array}$ & $\begin{array}{l}5.8-8.5 / \\
6.6\end{array}$ & $\begin{array}{l}1.0-30.0 \\
\text { by } 0.5-0.7\end{array}$ & $\begin{array}{l}\text { arabinose, cellobiose, fructose, galactose, } \\
\text { glucose, lactose, maltose, mannose, } \\
\text { raffinose, rhamnose, ribose, starch, } \\
\text { sucrose, xylose, } \\
\text { xylan, pyruvate. }\end{array}$ & $\begin{array}{l}1.0-20.0 / \\
3.0\end{array}$ & $\begin{array}{l}S^{0} \\
\text { Thio, } \\
\text { Sulfite }\end{array}$ & $\begin{array}{l}\text { AA, LA, } \mathrm{H}_{2,} \\
\mathrm{CO}_{2}, \mathrm{ALA}^{2}\end{array}$ & [96] \\
\hline & $\begin{array}{l}\text { Petrotoga } \\
\text { japonica }\end{array}$ & $\begin{array}{l}\text { Oil } \\
\text { reservoir, } \\
\text { Japan }\end{array}$ & $\begin{array}{l}40-65 / \\
60\end{array}$ & $\begin{array}{l}6.0-9.0 / \\
7.5\end{array}$ & $\begin{array}{l}2.5-7.0 \\
\text { by } 0.25-0.75\end{array}$ & $\begin{array}{c}\text { starch, xylan, maltose, cellobiose, sucrose, } \\
\text { lactose, glucose, galactose, fructose, } \\
\text { casamino acids, mannose, arabinose, } \\
\text { xylose, ribose }\end{array}$ & $\begin{array}{l}0.5-9.0 / \\
0.5-1.0\end{array}$ & $\begin{array}{l}S^{0} \\
\text { Thio }\end{array}$ & $\begin{array}{c}\mathrm{AA}, \mathrm{H}_{2} \\
\mathrm{CO}_{2}, \mathrm{ALA}\end{array}$ & [97] \\
\hline \multirow{6}{*}{ Marinitoga } & $\begin{array}{l}\text { Marinitoga } \\
\text { piezophila }\end{array}$ & $\begin{array}{l}\text { Hydrothermal } \\
\text { chimney, } \\
\text { Pacific } \\
\text { Ocean }\end{array}$ & $\begin{array}{l}45-70 / \\
65\end{array}$ & $\begin{array}{l}5.0-8.0 / \\
\quad 6.0\end{array}$ & $\begin{array}{l}1.0-1.5 \\
\text { by } 0.5\end{array}$ & $\begin{array}{l}\text { starch, fructose, glucose, galactose, } \\
\text { maltose, cellobiose, ribose, acetate }\end{array}$ & $\begin{array}{l}1.0-5.0 / \\
3.0\end{array}$ & $\begin{array}{l}S^{0}, \\
\text { Thio, } \\
\text { Cys }\end{array}$ & n.d. & [98] \\
\hline & $\begin{array}{l}\text { Marinitoga } \\
\text { litoralis }\end{array}$ & $\begin{array}{l}\text { Hot spring, } \\
\text { Indian } \\
\text { Ocean }\end{array}$ & $\begin{array}{l}45-70 / \\
65\end{array}$ & $\begin{array}{l}5.5-7.5 / \\
6.0\end{array}$ & $\begin{array}{c}1.0-7.0 \\
\text { by } 0.8-1.0\end{array}$ & $\begin{array}{l}\text { cellobiose, galactose, glucose, glycogen, } \\
\text { lactose, maltose, ribose, starch, BHI, } \\
\text { casamino acids, casein, peptone, } \\
\text { pyruvate, tryptone, YE }\end{array}$ & $\begin{array}{l}0.8-4.6 / \\
2.6\end{array}$ & $S^{0}$ & n.d. & [99] \\
\hline & $\begin{array}{l}\text { Marinitoga } \\
\text { okinawensis }\end{array}$ & $\begin{array}{l}\text { Hydrothermal } \\
\text { field, } \\
\text { Okinawa } \\
\end{array}$ & $\begin{array}{l}30-70 / \\
55-60\end{array}$ & $\begin{array}{l}5.5-7.4 / \\
5.5-5.8\end{array}$ & $\begin{array}{l}1.5-5.0 \\
\text { by } 0.5-0.8\end{array}$ & $\begin{array}{l}\text { YE, tryptone, peptone, starch, glucose, } \\
\text { glycerol }\end{array}$ & $\begin{array}{l}1.0-5.5 / \\
3.0-3.5\end{array}$ & $\begin{array}{l}S^{0} \\
\text { Cys }\end{array}$ & n.d. & [100] \\
\hline & $\begin{array}{c}\text { Marinitoga } \\
\text { hydrogenitolerans }\end{array}$ & $\begin{array}{l}\text { Hydrothermal } \\
\text { chimney, } \\
\text { Atlantic } \\
\text { Ocean }\end{array}$ & $\begin{array}{l}35-65 / \\
60\end{array}$ & $\begin{array}{l}4.5-8.5 / \\
\quad 6.0\end{array}$ & $\begin{array}{l}1.5-5.0 \\
\text { by } 0.5-0.8\end{array}$ & $\begin{array}{l}\text { glucose, starch, glycogen, chitin, YE, } \\
\text { BHI, peptone, casein, pyruvate, maltose }\end{array}$ & $\begin{array}{l}1.0-6.5 / \\
3.0-4.0\end{array}$ & $\begin{array}{l}\text { S }^{0} \\
\text { Thio, } \\
\text { Cys }\end{array}$ & $\begin{array}{l}\mathrm{AA}, \mathrm{EtOH} \\
\mathrm{Fo}, \mathrm{H}_{2}, \mathrm{CO}_{2}\end{array}$ & [101] \\
\hline & $\begin{array}{l}\text { Marinitoga } \\
\text { artica }\end{array}$ & $\begin{array}{l}\text { Hydrothermal } \\
\text { chimney, } \\
\text { Norwegian }\end{array}$ & $\begin{array}{l}45-70 / \\
65\end{array}$ & $\begin{array}{l}5.0-7.5 / \\
5.5\end{array}$ & $\begin{array}{l}1.0-5.0 \\
\text { by } 0.5-0.8\end{array}$ & $\begin{array}{l}\text { glucose, trehalose, maltose, sucrose, } \\
\text { maltodextrin, starch, pectin, meat extract, } \\
\text { tryptone, YE, pyruvate, fructose, } \\
\text { mannose, cellobiose, cellulose, peptone }\end{array}$ & $\begin{array}{l}1.5-5.5 / \\
2.5\end{array}$ & $\begin{array}{l}S^{0} \\
\text { Cys }\end{array}$ & n.d. & [102] \\
\hline & $\begin{array}{l}\text { Marinitoga } \\
\text { camini }\end{array}$ & $\begin{array}{l}\text { Hydrothermal } \\
\text { chimney, } \\
\text { Atlantic } \\
\text { Ridge }\end{array}$ & $\begin{array}{c}25-65 / \\
55\end{array}$ & $\begin{array}{l}5.0-9.0 / \\
7.0\end{array}$ & $\begin{array}{l}2.0-3.0 \\
\text { by } 0.5-1.0\end{array}$ & $\begin{array}{l}\text { BHI, gluten, peptone, tryptone, pyruvate, } \\
\text { glucose, fructose, maltose, cellobiose, } \\
\text { sucrose, starch, cellulose, CMC, pectin, } \\
\text { chitin }\end{array}$ & $\begin{array}{l}1.0-4.5 / \\
2.0\end{array}$ & $\begin{array}{l}S^{0} \\
\text { Cys }\end{array}$ & $\begin{array}{l}\text { AA, iBut, } \\
\text { iVal, } \mathrm{H}_{2} \\
\text { 3-IAA, LA } \\
\mathrm{CO}_{2} \text {, HPA, } \\
\text { PA }\end{array}$ & [11] \\
\hline Oceanotoga & $\begin{array}{l}\text { Oceanotoga } \\
\text { teriensis }\end{array}$ & $\begin{array}{l}\text { Offshore oil, } \\
\text { India }\end{array}$ & $\begin{array}{l}25-70 / \\
55-58\end{array}$ & $\begin{array}{l}5.5-9.0 / \\
7.5\end{array}$ & $\begin{array}{l}1.5-1.7 \text { by } \\
0.5-0.7\end{array}$ & $\begin{array}{l}\text { glucose, fructose, cellobiose, arabinose, } \\
\text { raffinose, rhamnose, sucrose, xylose, } \\
\text { ribose, starch, EtOH, formate, acetate, } \\
\text { BHI, YE, bio-trypticase }\end{array}$ & $\begin{array}{l}0.0-12 / \\
4.3\end{array}$ & $\begin{array}{l}S^{0} \\
\text { Thio }\end{array}$ & $\begin{array}{c}\mathrm{AA}, \mathrm{H}_{2} \\
\mathrm{CO}_{2}, \mathrm{EtOH}\end{array}$ & [12] \\
\hline Defluviitoga & $\begin{array}{l}\text { Defluviitog } \\
\text { tunisiensis }\end{array}$ & $\begin{array}{l}\text { Mesothermic } \\
\text { digester }\end{array}$ & $\begin{array}{l}37-65 / \\
55\end{array}$ & $\begin{array}{l}6.7-7.9 / \\
6.9\end{array}$ & $\begin{array}{l}3.0-30.0 \\
\text { by } 1.0\end{array}$ & $\begin{array}{l}\text { arabinose, cellobiose, fructose, galactose, } \\
\text { glucose, lactose, maltose, mannose, } \\
\text { raffinose, ribose, sucrose, xylose, } \\
\text { cellulose, xylan }\end{array}$ & $\begin{array}{l}0.2-3.0 / \\
0.5\end{array}$ & $\begin{array}{l}S^{0} \\
\text { Thio }\end{array}$ & $\begin{array}{l}\mathrm{AA}, \mathrm{H}_{2} \\
\mathrm{CO}_{2}\end{array}$ & [9] \\
\hline
\end{tabular}


Table 1. Cont.

\begin{tabular}{|c|c|c|c|c|c|c|c|c|c|c|}
\hline Genus & Species & Isolation & $\begin{array}{l}\text { Temp. Range/ } \\
\text { Optimal }\left({ }^{\circ} \mathrm{C}\right)\end{array}$ & $\begin{array}{c}\mathrm{pH} \\
\text { Range/ } \\
\text { Optimal }\end{array}$ & $\begin{array}{c}\text { Cell } \\
\text { Dimension } \\
(\text { Long by Wide) } \\
(\mu \mathrm{m})\end{array}$ & Growth Substrates & $\begin{array}{c}\text { NaCl Range/ } \\
\text { Optimal } \\
(\%)\end{array}$ & $\begin{array}{l}\text { Electron } \\
\text { Acceptor }\end{array}$ & $\begin{array}{l}\text { End } \\
\text { Products }\end{array}$ & Ref. \\
\hline \multirow{2}{*}{ Mesotoga } & $\begin{array}{l}\text { Mesotoga } \\
\text { infera }\end{array}$ & $\begin{array}{l}\text { Deep } \\
\text { aquifer, } \\
\text { France }\end{array}$ & $\begin{array}{l}30-50 / \\
45\end{array}$ & $\begin{array}{l}6.2-7.9 / \\
7.4\end{array}$ & $\begin{array}{c}2.0-4.0 \\
\text { by } 1.0-2.0\end{array}$ & $\begin{array}{l}\text { arabinose, cellobiose, fructose, galactose, } \\
\text { glucose, lactose, LA, mannose, maltose, } \\
\text { raffinose, ribose, sucrose, xylose }\end{array}$ & $\begin{array}{l}0.0-1.5 / \\
0.2\end{array}$ & $S^{0}$ & $\mathrm{AA}, \mathrm{CO}_{2}$ & [26] \\
\hline & $\begin{array}{l}\text { Mesotoga } \\
\text { prima }\end{array}$ & $\begin{array}{l}\text { Sediment, } \\
\text { USA }\end{array}$ & $\begin{array}{c}20-50 / \\
37\end{array}$ & $\begin{array}{l}6.5-8.0 / \\
7.5\end{array}$ & 1.0 by 0.2 & $\begin{array}{l}\text { xylose, fructose, ribose, sucrose, mannose, } \\
\text { galactose, maltose, lactose, peptone, } \\
\text { tryptone, casamino acids, glucose, } \\
\text { arabinose, cellobiose, casein, pyruvate }\end{array}$ & $\begin{array}{c}2.0-6.0 / \\
4.0\end{array}$ & $\begin{array}{l}S^{0}, \\
\text { Thio, } \\
\text { Sulfite }\end{array}$ & $\begin{array}{l}\text { AA, But, } \\
\text { iBut, iVal, } \\
\text { 2-MeBu }\end{array}$ & [8] \\
\hline \multirow{4}{*}{ Kosmotoga } & $\begin{array}{l}\text { Kosmotoga } \\
\text { arenicorallina }\end{array}$ & $\begin{array}{l}\text { Hot spring, } \\
\text { Japan }\end{array}$ & $\begin{array}{c}50-65 / \\
60\end{array}$ & $\begin{array}{l}6.2-8.0 / \\
7.1\end{array}$ & $\begin{array}{c}1.1-2.7 \\
\text { by } 1.1-1.9\end{array}$ & xylose, maltose, glycerol & $\begin{array}{l}1.0-6.0 / \\
3.0\end{array}$ & $\begin{array}{l}S^{0}, \\
\text { Cys }\end{array}$ & n.d. & [103] \\
\hline & $\begin{array}{l}\text { Kosmotoga } \\
\text { pacifica }\end{array}$ & $\begin{array}{l}\text { Hydrothermal } \\
\text { field, Pacific } \\
\text { Ocean }\end{array}$ & $\begin{array}{c}33-78 / \\
70\end{array}$ & $\begin{array}{l}6.2-8.0 / \\
7.1\end{array}$ & 1.0 by 0.6 & $\begin{array}{c}\text { maltose, YE, peptone, BHI, glycerol, } \\
\text { tryptone, xylose, glucose, fructose, } \\
\text { cellobiose, trehalose, LA, propionate, } \\
\text { glutamate }\end{array}$ & $\begin{array}{l}0.5-6.0 / \\
\text { n.d. }\end{array}$ & $\begin{array}{l}S^{0}, \\
\text { Cys }\end{array}$ & n.d. & [104] \\
\hline & $\begin{array}{c}\text { Kosmotoga } \\
\text { olearia }\end{array}$ & $\begin{array}{l}\text { Fluid, } \\
\text { North Sea }\end{array}$ & $\begin{array}{c}20-80 / \\
65\end{array}$ & $\begin{array}{l}5.5-8.0 / \\
6.8\end{array}$ & $\begin{array}{c}0.8-1.2 \\
\text { by } 0.4-0.7\end{array}$ & $\begin{array}{l}\text { maltose, ribose, sucrose, starch, } \\
\text { casamino acids, tryptone, pyruvate }\end{array}$ & $\begin{array}{l}1.0-6.0 / \\
2.5-3.0\end{array}$ & Thio & $\begin{array}{l}\mathrm{H}_{2}, \mathrm{CO}_{2} \\
\text { AA, EtOH, } \\
\text { PPA }\end{array}$ & [7] \\
\hline & $\begin{array}{l}\text { Kosmotoga } \\
\text { shengliensis }\end{array}$ & $\begin{array}{l}\text { Oilfield, } \\
\text { China }\end{array}$ & $\begin{array}{l}45-75 / \\
65\end{array}$ & $\begin{array}{l}6.0-8.0 / \\
7.0\end{array}$ & $0.7-0.9$ & $\begin{array}{l}\text { glucose, acetate, } \mathrm{mEtOH} \text {, galactose, } \\
\text { fructose, xylose, sucrose, maltose, } \\
\text { sorbitol, lactose, } \\
\text { xylan, arabinose, formate, rhamnose, } \\
\text { glycerol, pyruvate, starch, LA }\end{array}$ & $\begin{array}{l}0.0-4.0 / \\
1.5\end{array}$ & $\begin{array}{l}S^{0}, \\
\text { Thio, } \\
\text { Sulfate }\end{array}$ & $\begin{array}{l}\text { AA, LA, } \\
\text { ALA, } \mathrm{CO}_{2} \\
\mathrm{H}_{2}\end{array}$ & [15] \\
\hline Athalassatoga & $\begin{array}{l}\text { Athalassatoga } \\
\text { saccharophila }\end{array}$ & $\begin{array}{l}\text { Hot spring, } \\
\text { Japan }\end{array}$ & $\begin{array}{l}30-60 / \\
55\end{array}$ & $\begin{array}{l}4.5-7.5 / \\
5.5-6.0\end{array}$ & $\begin{array}{l}0.8-2.0 \\
\text { by } 0.7-0.8\end{array}$ & $\begin{array}{l}\text { arabinose, fructose, glucose, lactose, } \\
\text { maltose, mannose, ribose, sucrose, } \\
\text { xylose, starch, glycogen, peptone, YE }\end{array}$ & $<1 / 0.0$ & $\begin{array}{l}\text { Fe (III), } \\
\text { Thio, } \\
\text { Cys }\end{array}$ & $\begin{array}{l}\text { AA, iBut, } \\
\text { iVal }\end{array}$ & [14] \\
\hline Mesoaciditoga & $\begin{array}{l}\text { Mesoaciditoga } \\
\text { lauensis }\end{array}$ & $\begin{array}{l}\text { Hydrothermal } \\
\text { vent, } \\
\text { Pacific } \\
\text { Ocean }\end{array}$ & $\begin{array}{l}45-65 / \\
57-60\end{array}$ & $\begin{array}{l}4.1-6.0 / \\
5.5-5.7\end{array}$ & $\begin{array}{l}0.8-1.0 \\
\text { by } 0.4\end{array}$ & $\begin{array}{l}\text { YE, peptone, maltose, sucrose, glucose, } \\
\text { xylose, ribose, starch, tryptone }\end{array}$ & $\begin{array}{l}0.5-6.0 / \\
3.0\end{array}$ & $\begin{array}{l}S^{0} \\
\text { Thio, } \\
\text { Cys }\end{array}$ & n.d. & [13] \\
\hline
\end{tabular}




\section{Operating Conditions}

\section{1. $\mathrm{H}_{2}$ Partial Pressure $\left(P_{\mathrm{H} 2}\right)$}

Since Thermotogae members are hydrogen producers, tolerance to hydrogen produced by the bacteria on its own gaseous production, known as the "hydrogen partial pressure $\left(P_{\mathrm{H} 2}\right)$ " effect, is one of the primary parameters being extensively investigated [51,70,105]. The highest hydrogen tolerance has been observed in the genus Marinitoga. Mn. camini and $M n$. piezophila were able to grow with $\mathrm{H}_{2}$ concentrations up to $40 \%$ and $60 \%$, respectively. $\mathrm{Mn}$. hydrogenitolerans and Mn. okinawensis can grow under $100 \% \mathrm{H}_{2}$ atmosphere with only minor inhibition on growth and fermentation $[100,101]$. Their remarkable resistance to high $\mathrm{H}_{2}$ levels is probably related to the typical habitats in which Marinotoga species thrive [100]. However, the growth of Thermotogae species is often inhibited by $\mathrm{H}_{2}$ accumulation, and the metabolism of these organisms undergoes a series of rearrangements to suit $P_{\mathrm{H} 2}$ levels in the bioreactor headspace. The majority of literature data refers to $\mathrm{H}_{2}$ percentages in gaseous phase, although some studies have been reporting values of $P_{\mathrm{H} 2}$. Partial pressure around 607 mbar led to decreased levels of biomass production, glucose consumption rate, and $\mathrm{H}_{2}$ production in both T. neapolitana and T. maritima [106,107]. Boileau et al. [107] highlighted a shift of T. maritima glucose catabolism from acetic acid towards lactic acid when $P_{\mathrm{H} 2}$ increased from 7 to 607 mbar (Table 2) [106,107]. In contrast, low $P_{\mathrm{H} 2}$ (less than 80 mbar) promoted acetic acid accumulation. Biomass production and glucose consumption rate are unaffected when $P_{\mathrm{H} 2}$ is maintained within the range of 7.1-178.5 mbar (Table 2) [105,106]. In fact, $P_{\mathrm{H} 2}$ lower than $200 \mathrm{mbar}$ is required for optimal growth in reactors, and $P_{\mathrm{H} 2}$ around 2900 mbar completely inhibits growth in T. maritima $[1,45,49,108,109]$.

Hydrogen evolution is driven by a bifurcating hydrogenase $\left(\mathrm{H}_{2}\right.$ ase) that couples the oxidation of reduced ferredoxin (Fd) and NADH with the reduction of protons to $\mathrm{H}_{2}$ (Figure 1) [58]. In dark fermentation, pyruvate is converted to acetate and ATP, which thermodynamically drives the $\mathrm{H}_{2}$-acetate pathway. Under high $\mathrm{H}_{2}$ partial pressure, hydrogenase activity is inhibited, NADH consumption stops, pyruvate is diverted away from acetic acid production, and lactic acid synthesis becomes the only mechanism for recycling reduced electron carriers (Figure 1) [28-30,57,64,106,110]. Synthesis of lactic acid by the lactate dehydrogenase (LDH) catalyzes the conversion of pyruvate to lactate with the concomitant conversion of NADH to NAD+ (Figure 1). The depletion of the pyruvate pool, as occurs with the synthesis of lactic acid, negatively affects hydrogen yield, preventing it from reaching the theoretical maximal value (Figure 1) [24]. This problem can be overcome by enhancing the liquid-to-gas mass transfer and keeping $\mathrm{H}_{2}$ concentrations low in experimental conditions (See Section 2.2) or by using mixed cultures with microbial species that are able to oxidize $\mathrm{H}_{2}[27,111]$. 

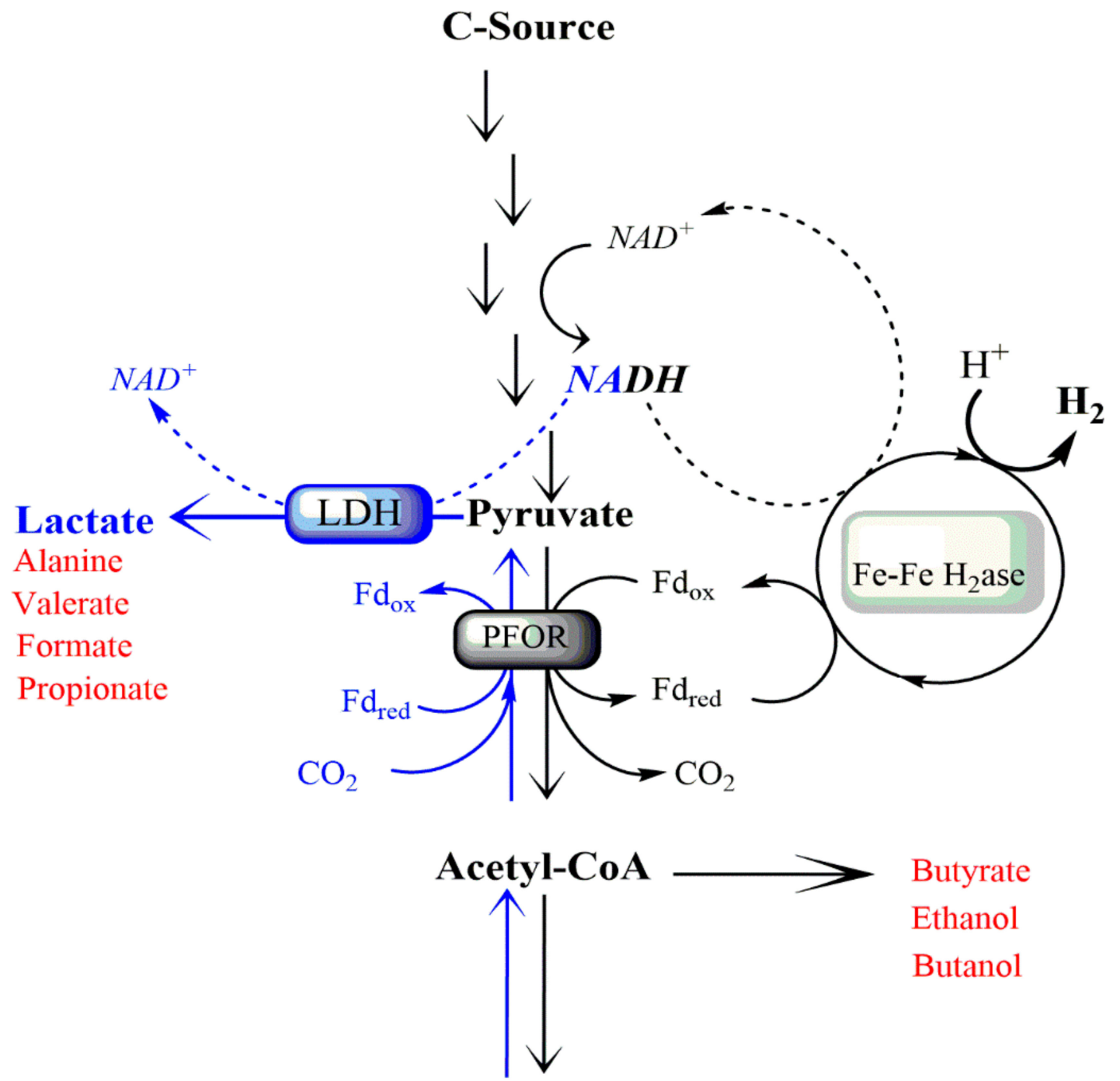

\begin{abstract}
Acetate
Figure 1. Schematic representation of Thermotogae metabolic fermentation. Dark fermentation (black arrows) of glucose leads to the production of $\mathrm{H}_{2}$ and acetate. An increase in $\mathrm{CO}_{2}$ concentration in the reactor headspace induces the recycling of Ac$\mathrm{CoA}$ and $\mathrm{CO}_{2}$ into lactate without impairing the synthesis of biogas (blue arrows). This process is named "Capnophilic lactic fermentation (CLF)" $[30,31,56,70]$. The main end-products of Thermotogae fermentation are $\mathrm{H}_{2}$, lactate, and acetate. Other fermentation products are reported in red. $\mathrm{Fe}-\mathrm{Fe} \mathrm{H}_{2}$ ase = $[\mathrm{Fe}-\mathrm{Fe}]$ hydrogenase; PFOR = Pyruvate ferredoxin oxidoreductase; $\mathrm{LDH}=$ Lactate dehydrogenase; Fd = Ferredoxin.
\end{abstract}

\title{
2.2. Shaking Speed, Culture/Headspace Volume Ratio, Gas Sparging, and Inoculum
}

Growth and metabolism of thermophilic bacteria are reported to be strongly affected by an increase in the hydrogen level, which makes the metabolic reactions thermodynamically unfavorable [112]. Many effective strategies have been developed to overcome the $\mathrm{H}_{2}$ feedback inhibition, such as gas sparging, vigorous stirring, or simply increasing the gas/liquid volume ratio in the reactor. $\mathrm{H}_{2}$ saturation is dependent on the partial pressure of hydrogen in the culture medium and its mass transfer from liquid to gas phase. As a matter of fact, the mass transfer of $\mathrm{H}_{2}$ from liquid to gas can be improved by applying vigorous agitation in bioreactors $[69,106]$. Increased $\mathrm{H}_{2}$ production rate, glucose consumption rate, and lactic acid synthesis have been observed in T. neapolitana cultures with agitation at $200 \mathrm{rpm}$, compared to static cultures, although the final $\mathrm{H}_{2}$ yields were similar [106]. Comparable hydrogen yields were also observed when the agitation speed was 300 and 500 rpm, e.g., 
$3.0 \pm 0.0 \mathrm{~mol} \mathrm{H}_{2} / \mathrm{moL}$ glucose at $300 \mathrm{rpm}$ vs. $3.2 \pm 0.1 \mathrm{moL} \mathrm{H}_{2} / \mathrm{moL}$ glucose at $500 \mathrm{rpm}$, with a mild improvement in fermentation rate (Table 2) [69]. In xylose fermentation, the highest hydrogen and organic acid yields have been reported at $400 \mathrm{rpm}$ when tested in the range of 300-600 rpm [113].

To improve hydrogen liquid-gas mass transfer, Dreschke et al. [69] designed a new method that recirculated the $\mathrm{H}_{2}$-rich biogas $(\mathrm{GaR})$ into the T. neapolitana subs. capnolactica broth with agitation (300, $500 \mathrm{rpm}$ ). This combination accelerated the $\mathrm{H}_{2}$ evolution rate and glucose consumption rate during glucose fermentation, compared to the treatments including agitation but excluding GaR. Nonetheless, levels of the end-products, except for $\mathrm{H}_{2}$ yield, were not significantly altered by the combined parameters (Table 2) [69].

Since $P_{\mathrm{H} 2}$ depends on the culture/headspace volume ratio in the bioreactors, its impacts on the performance of fermentation have also been investigated, mainly in batch reactors. Nguyen et al. [64] have experimented various culture/headspace volume ratio from $8.3 \%(10 \mathrm{~mL} / 120 \mathrm{~mL})$ up to $50 \%(60 \mathrm{~mL} / 120 \mathrm{~mL})$ in T. neapolitana and T. maritima cultures [64]. At $8.3 \%$, the $\mathrm{H}_{2}$ production is the highest for both species $\left(890 \mathrm{~mL} \mathrm{H}_{2} / \mathrm{L}\right.$ medium in T. neapolitana and $883 \mathrm{~mL} \mathrm{H} \mathrm{H}_{2} / \mathrm{L}$ medium in T. maritima). $\mathrm{H}_{2}$ production gradually diminished, and lactic acid production was promoted with increasing culture volumes $[30,64,110]$. d'Ippolito et al. [30] found 1:3 culture/headspace volume was the most suitable ratio for high hydrogen yields [30]. When these conditions were optimized, T. neapolitana resulted in $\mathrm{H}_{2}$ yields between $3.46-3.85 \mathrm{~mol} \mathrm{H}_{2} / \mathrm{mol}$ glucose [30,114].

Gas sparging, mainly with $\mathrm{N}_{2}$, is the most common method to reduce hydrogen partial pressure by removing $\mathrm{H}_{2}$ and $\mathrm{CO}_{2}$ produced from sugar fermentation in closed bioreactors $[56,108,115,116]$. Under nitrogen sparging conditions, the overall yield of $\mathrm{H}_{2}$ in T. neapolitana fermentation was about two-fold of the non-sparged cultures, e.g., 1.82 vs. $3.24 \mathrm{moL} \mathrm{H}_{2} / \mathrm{moL}$ glucose or 1.14 vs. $2.20 \mathrm{moL} \mathrm{H}_{2} / \mathrm{moL}$ xylose (Table 2). The levels of acetic acid and butyrate also increased [110]. Moreover, the fermentation performance was remarkably improved when $\mathrm{N}_{2}$ - sparging was coupled with $\mathrm{pH}$ control in T. neapolitana using pure glycerol as the sole carbon source (Table 2) [116]. Keeping $\mathrm{pH}$ close to neutral improved the glucose utilization and $\mathrm{H}_{2}$-acetate production rates. In contrast, lactic acid production was lowered under these conditions $(0.255 \mathrm{mmol} / \mathrm{L}$ with $\mathrm{pH}$ control and sparging vs. $0.36 \mathrm{mmol} / \mathrm{L}$ with $\mathrm{pH}$ control but no sparging) (Table 2) [116]. The use of a $\mathrm{CO}_{2}$-enriched atmosphere significantly increased both glucose consumption rate and hydrogen production rate, even though the molar yield was comparable to that of $\mathrm{N}_{2}$-sparging (Table 2) [31]. Surprisingly, supplementation of $\mathrm{CO}_{2}$ to T. neapolitana cultures induced an unexpected metabolic shift from acetic to lactic fermentation without any significant change in hydrogen production ( $3.6 \mathrm{moL} / \mathrm{moL}$ glucose) (Table 2) [31]. Experiments with labeled precursors revealed that part of the exogenous $\mathrm{CO}_{2}$ was biologically coupled with acetyl-CoA to give lactic acid when the cultures were sparged with $\mathrm{CO}_{2}$ gas or enriched in sodium bicarbonate (Figure 1) [117]. This process, named Capnophilic Lactic Fermentation (CLF), has the surprising feature to produce more lactic acid than expected from the classical dark fermentation model where $\mathrm{H}_{2}$ production is impaired by the onset of by-passing pathways (Figure 1) [31,56,117-119]. In dark fermentation, hydrogen and lactic acid levels competed for a common pool of reducing power. Whereas, in CLF, the $\mathrm{H}_{2}$ level remained high, probably due to additional sources of reductants to sustain NADH-dependent pathways (Figure 1) [118-120]. Recently, an additional increase in lactic acid production occurred in a T. neapolitana mutant that was isolated from a culture adapted to continuous exposure to $\mathrm{CO}_{2}$ [62]. Sparging with $\mathrm{CO}_{2}$ was also performed on the culture of other Thermotogales species, whose metabolic response was qualitatively and quantitatively diverse (Table 2) [70]. $\mathrm{CO}_{2}$-enriched conditions promoted glucose consumption rate and lowered biogas production in almost all tested species [70]. T. caldifontis, Pseudot. elfii, Pseudot. thermarum, Pseudot. lettingae, and Pseudot. subterranea did not show substantial variations in the levels of the fermentation products compared to cultures in an $\mathrm{N}_{2}$-enriched atmosphere [70]. T. neapolitana, T. maritima, T. profunda, and Pseudot. hypogea species responded to $\mathrm{CO}_{2}$ by reducing the fermentation rate. T. neapolitana subsp. capno- 
lactica was the only species to increase lactic acid and $\mathrm{H}_{2}$ yield moving from $\mathrm{N}_{2}$-sparging to $\mathrm{CO}_{2}$-sparging [70]. Generally speaking, the supplementation of external gas $\left(\mathrm{N}_{2}\right.$ or $\mathrm{CO}_{2}$ ) successfully improves the fermentation performance in most species and lowers the inhibitory effect of $\mathrm{H}_{2}$ accumulation, but it inevitably causes an undesired dilution of hydrogen in evolved gases. In this context, the recirculation of the $\mathrm{H}_{2}$-rich biogas method prevents hydrogen saturation in the bioreactor without negatively affecting the content of the produced biogas [69].

The initial biomass concentration (size of inoculum) also has an unexpected impact on the fermentation of thermophilic bacteria. Using various initial biomass concentrations of T. neapolitana subs. capnolactica (in the range of $0.46-1.74 \mathrm{~g} \mathrm{CDW} / \mathrm{L}$ ) under $\mathrm{CO}_{2}$ atmosphere, hydrogen yield and the distribution of end-products were unaffected (Table 2) [68]. However, increasing inoculum size from 0.46 to $1.74 \mathrm{~g} / \mathrm{L}$ reduced the fermentation time from $7 \mathrm{~h}$ to $3 \mathrm{~h}$ [68]. Moreover, the hydrogen production rate, glucose consumption rate, and biomass growth rate were increased [49,50,68]. It is worth pointing out that Ngo et al. [116] reported a reverse correlation between hydrogen production rate and inoculum size, stating that high initial biomass corresponded to a mild reduction of hydrogen production rate [116].

\section{3. $p H$}

As the fermentation of sugars leads to the production and accumulation of organic acids, the $\mathrm{pH}$ is decreasing during the process, which may inhibit bacterial growth before the substrates are completely consumed $[30,106,113]$. Two factors impose a strong inhibition on bacterial growth and $\mathrm{H}_{2}$ production: rapid decrease in $\mathrm{pH}$ due to the accumulation of byproducts and feedback inhibition caused by $\mathrm{H}_{2}$ accumulated in the headspace $[65,105-108,113,121]$.

Thus, $\mathrm{pH}$ is a critical factor to control sugar consumption and direct end-products formation $[65,67,117,119,122]$. Gradual pH drop causes enzyme activity loss [123]. To overcome $\mathrm{pH}$-induced limitations on Thermotogae fermentation, several studies were performed with $\mathrm{pH}$ adjustments $[51,67,121]$. In $\mathrm{pH}$-controlled cultures $(\sim 6.5-7.0), \mathrm{H}_{2}$ and acetic acid production predominated over lactic acid and peaked around $20 \mathrm{~h}$ [113]. In contrast, lactic acid production only started when $\mathrm{pH}$ declined to around 5.0 [113].

The addition of $\mathrm{NaOH}$ at regular intervals and the use of buffering reagents have been regarded as the best-performing methods with serum bottles $[56,66,67,113]$. The optimum $\mathrm{pH}$ for growth and hydrogen production is 6.5-7.0 in T. maritima and 6.5-7.5 in T. neapolitana depending on substrates and growth conditions $[64,113,122]$. Moreover, $\mathrm{pH}$ 7.0 provides the most promising results in terms of $\mathrm{H}_{2}$ and organic acids production in T. neapolitana [113,122]. A pH shift from 5.5 to 7.0 improved $\mathrm{H}_{2}$ yield from 125 to $198 \mathrm{~mL} \mathrm{H}_{2} / \mathrm{L}$ medium in T. neapolitana [61]. With T. neapolitana cells immobilized on ceramic surfaces using glucose as the carbon source, the highest hydrogen production was observed in the $\mathrm{pH}$ range of 7.7-8.5 [51]. Further increase in the range of $\mathrm{pH}$ to 8.0-9.0 led to a dramatic decrease in the biogas evolution [64].

Different organic and inorganic buffers have been examined for their effect on anaerobic fermentation under various growth conditions and buffer concentrations [51]. According to Cappelletti et al. [51], 0.1 M HEPES resulted in the best performance, compared to MOPS, PIPES, $\mathrm{HPO}_{4}{ }^{-} / \mathrm{H}_{2} \mathrm{PO}_{4}{ }^{-}$, or Tris- $\mathrm{HCl}$ buffer in T. neapolitana batch cultures growing on glucose under $\mathrm{N}_{2}$ atmosphere [51]. The good buffering properties of HEPES, whose $\mathrm{pK}$ (7.55) is near the optimal $\mathrm{pH}$ of T. neapolitana, was also demonstrated for T. neapolitana cultures growing on different complex carbon sources (cheese whey, molasses, or waste glycerol) [51,122]. In another study, 0.05 M HEPES was found to be sufficient under $\mathrm{N}_{2}$ sparging atmosphere (Table 2) [113]. Under CLF conditions, 0.01 M MOPS, TRIS, or HEPES buffers provided satisfactory results for both $\mathrm{H}_{2}$ and lactic acid synthesis in T. neapolitana subs. capnolactica (Table 2) [67]. More specifically, $\mathrm{H}_{2}$ synthesis was found to be the highest in MOPS, while TRIS promoted acetic acid formation (Table 2) [67]. The highest value of 
lactic acid synthesis was $14.9 \pm 0.3 \mathrm{mM}$ in phosphate buffer compared to $11.3 \pm 0.6 \mathrm{mM}$ in the standard condition (Table 2) [67].

The buffering capacity of $\mathrm{HCO}_{3}{ }^{-}$is sufficient to maintain near to optimal $\mathrm{pH}$ for growth $(\sim 6.5)$, facilitating the complete substrate degradation and desired by-product formation (Table 2) $[31,56,67]$.

In other studies, itaconic acid was successfully used as a physiological buffer to enhance hydrogen production in T. neapolitana growing on glucose or glycerol [121,122]. During the cultivation with $1.5 \mathrm{~g} / \mathrm{L}$ itaconic acid, the $\mathrm{pH}$ slowly dropped from 7.5 to 6.8 over $99 \mathrm{~h}$, while the same $\mathrm{pH}$ change was reached within $48 \mathrm{~h}$ in cultures not buffered [122]. Although itaconic acid is only poorly catabolized, it affected the overall metabolism of $T$. neapolitana because $\mathrm{H}_{2}$ and acetic acid production were almost 1.4-fold higher than the control, while lactic acid production was reduced by nearly $100 \%$ compared to the control (Table 2) [122]. In addition, Ngo and Sim [122] found that the performance of T. neapolitana fermentation growing on waste glycerol was improved by almost $40 \%$ by adding itaconic acid into the culture medium [122].

\subsection{Temperature}

Due to their origin from hot habitats, bacterial species of the phylum Thermotogae can live and grow at temperatures in the range of $40-90{ }^{\circ} \mathrm{C}$ (Table 1). Some species such as K. olearia, O. teriensis, Ms. prima, and P. mexicana can thrive at mesophilic temperatures (Table 1) $[7,8,96,100]$, and other species such as F. changbaicum, F. thailandese, T. maritima, Pseudot. hypogea, and T. neapolitana share the ability of growing at temperatures close to $90{ }^{\circ} \mathrm{C}$ (Table 1) $[3,74,77,83,94]$. For a long time, researchers have selected an operating temperature of $70{ }^{\circ} \mathrm{C}[104,117]$ or $80{ }^{\circ} \mathrm{C}[105]$ to cultivate T. neapolitana and T. maritima without careful investigation of the impacts on fermentation. Nguyen et al. [64] explored changes of $\mathrm{H}_{2}$ production with temperatures ranging from 55 to $90{ }^{\circ} \mathrm{C}$ for T. neapolitana and T. maritima. Both cultures showed approximately $100 \mathrm{~mL} \mathrm{H}_{2} / \mathrm{L}$ medium at $55{ }^{\circ} \mathrm{C}$ and a maximum of $200 \mathrm{~mL} \mathrm{H} / 2$. medium at $75-80{ }^{\circ} \mathrm{C}$, with a decrease to $150 \mathrm{H}_{2} / \mathrm{L}$ medium at $90{ }^{\circ} \mathrm{C}$ [64]. In T. neapolitana, high temperatures $\left(77-85^{\circ} \mathrm{C}\right)$ enhanced glucose uptake $\left(2.2 \mathrm{mmol} / \mathrm{L}\right.$ at $60^{\circ} \mathrm{C}$ and $11.0 \mathrm{mmol} / \mathrm{L}$ at $\left.77-85^{\circ} \mathrm{C}\right)$ and boosted hydrogen yields (2.04 $\mathrm{mol} \mathrm{H}_{2} / \mathrm{moL}$ consumed glucose at $60^{\circ} \mathrm{C}$ and $3.85 \mathrm{~mol} \mathrm{H}_{2} / \mathrm{mol}$ at $77^{\circ} \mathrm{C}$ ) [65]. This positive effect was also found for acetic acid $\left(2.0 \mathrm{mmol} / \mathrm{L}\right.$ at $60^{\circ} \mathrm{C}$ and $18.0 \mathrm{mmol} / \mathrm{L}$ at $\left.85^{\circ} \mathrm{C}\right)$ and lactic acid production (no production at $60^{\circ} \mathrm{C}$ and $1.25 \mathrm{mmol} / \mathrm{L}$ at $85^{\circ} \mathrm{C}$ ) (Table 2) [65]. Studies conducted on T. maritima hydrogenase demonstrated that this enzyme is unstable at the ambient temperature and its activity increased considerably with rising temperature (an activity of 25 units $/ \mathrm{mg}$ at $20^{\circ} \mathrm{C}$ and 110 units $/ \mathrm{mg}$ at $90{ }^{\circ} \mathrm{C}$ [123].

\subsection{Oxygen $\left(\mathrm{O}_{2}\right)$}

Thermotogae members occur in various hot ecosystems, including hot springs, deepsea, and shallow hydrothermal vents, and may also be exposed to $\mathrm{O}_{2}$ in these ecological niches [1254]. Indeed, despite their anaerobic nature, $\mathrm{O}_{2}$ tolerance is variable in the phylum; for example, Thermotoga, Fervidobacterium, and Geotoga genera can grow only under strictly anaerobic conditions, while K. olearia can survive in up to $15 \% \mathrm{O}_{2}$ [10]. With elemental sulfur, Ts. atlanticus can grow with up to $8 \% \mathrm{O}_{2}$ in the headspace [92]. Geochemical and microbial analyses demonstrated the wide distribution of Thermotogae species in ecosystems that are not only anaerobic but also partially oxygenated [124]. For this reason, the question of $\mathrm{O}_{2}$ tolerance and microaerophilic metabolism of Thermotogae has been addressed by several studies $[65,105,106,125-129]$. Some researchers have demonstrated that low concentrations of $\mathrm{O}_{2}$ are tolerated by T. neapolitana and T. maritima [127,128]. An $\mathrm{O}_{2}$ insensitive hydrogenase has been described in T. neapolitana, explaining why microaerobic $\mathrm{H}_{2}$ production and $\mathrm{O}_{2}$ tolerance could take place in this bacterium [130]. Additionally, Pseudot. hypogea and T. maritima contain an NADH oxidase that may serve as an $\mathrm{O}_{2}$ detoxification system [131,132]. Lakhal et al. [129] demonstrated $\mathrm{O}_{2}$ consumption over $12 \mathrm{~h}$ during the stationary phase of T. maritima in a batch reactor without reducing agent [129]. $\mathrm{O}_{2}$ presence 
reduced glucose fermentation rate and significantly shifted metabolism towards lactic acid production in T. maritima (Table 2). This change can probably be explained by $\mathrm{O}_{2}$ sensitivity of the hydrogenase [129]. Furthermore, T. maritima overproduced enzymes involved in reactive oxygen species (ROS) detoxification, iron-sulfur cluster synthesis/repair, cysteine biosynthesis, and a flavoprotein homologous to the rubredoxin of Desulfovibrio species that exhibited an oxygen reductase activity [127].

Van Ooteghem et al. [121] reported that $\mathrm{O}_{2}$ concentration decreased during the growth of $F$. pennavorans, P. miotherma, Ts. africanus, Pseudot. elfii, and T. neapolitana. In these experiments, the $\mathrm{H}_{2}$ yield greatly exceeded the theoretical limit of $4 \mathrm{~mol} \mathrm{H}_{2} / \mathrm{mol}$ glucose in F. pennavorans, Pseudot. elfii, and T. neapolitana fermentation [121]. These surprisingly high $\mathrm{H}_{2}$ yield have led to the hypothesis of an unidentified aerobic pathway using $\mathrm{O}_{2}$ as a terminal electron acceptor in these bacteria which may not be obligate anaerobes [121]. However, aerobic metabolism is not supported by the genomic sequence of T. maritima, although the enzymes involved in the pentose phosphate pathway and an NADPH-reducing hydrogenase have been identified in the genome [16]. To explain the increased yield of $\mathrm{H}_{2}$ by T. neapolitana in microaerobic conditions and the existence of a catabolic process requiring $\mathrm{O}_{2}$, van Ooteghem et al. [121] used malonic acid as an inhibitor of succinate dehydrogenase and thus the $\mathrm{O}_{2}$-dependent metabolism. Even if the coding sequence for succinate dehydrogenase has not been identified in the T. maritima genome, hydrogen generation was completely inhibited for $>40 \mathrm{~h}$ in the presence of malonate, postulating that malonate in the medium was no longer available to block catabolism [121]. Then, Eriksen et al. [106] demonstrated that malonic acid was not metabolized by T. neapolitana cultures but the exposure to malonic acid clearly affected the metabolism as reduced production of lactic acid and increased $\mathrm{H}_{2}$ yield were observed [106]. Against these findings, other researchers reported a reduction of $\mathrm{H}_{2}$ rate and production in T. neapolitana cultures after the injection of $6 \% \mathrm{O}_{2}[65,106]$. The reduction of $\mathrm{O}_{2}$ consumes reducing equivalents that are then unvailable to produce $\mathrm{H}_{2}$. The total duration of T. maritima fermentation in the batch reactor was delayed about $67 \mathrm{~h}$ under $\mathrm{O}_{2}$-induced stress [129]. In addition, the consumption rate of glucose was drastically reduced and the metabolism of T. maritima shifted towards lactic acid production due to inhibition of the $\mathrm{O}_{2}$-sensitive hydrogenase [129].

From a technical point of view, several strategies were adopted to remove dissolved $\mathrm{O}_{2}$ in the bioreactor: [I] sparging the culture with $\mathrm{N}_{2}, \mathrm{CO}_{2}$ or a mixture of both gases; [II] heating the medium; [III] adding a reducing agent such as sodium sulfide or cysteine$\mathrm{HCl}$ in the medium; [IV] maintaining a positive pressure in the bioreactor headspace $[31,56,62,67,70,105,106,113,121]$. 


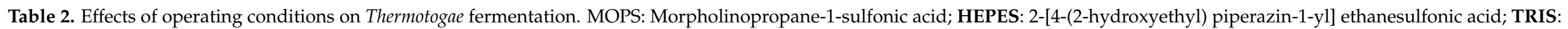

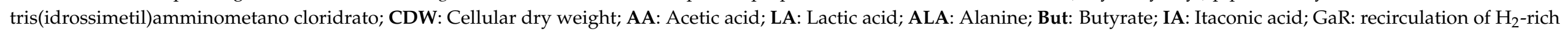

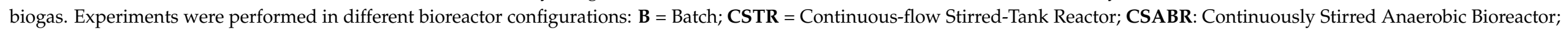
SB = Serum bottles. $\mathbf{H}_{2}$ column: ${ }^{a} \mathrm{H}_{2}$ yield $=$ mol $\mathrm{H}_{2} /$ mol consumed substrate; ${ }^{\mathrm{b}} \mathrm{mL} / \mathrm{L}$ culture. ${ }^{*}$ Values extrapolated from the graphical representation of data.

\begin{tabular}{|c|c|c|c|c|c|c|c|c|c|c|c|c|c|c|}
\hline \multirow[b]{2}{*}{ Parameter } & \multirow[b]{2}{*}{ Organism } & \multirow[b]{2}{*}{$\mathrm{T}\left({ }^{\circ} \mathrm{C}\right)$} & \multirow[b]{2}{*}{$\begin{array}{l}\text { Culture } \\
\text { Type }\end{array}$} & \multirow{2}{*}{$\begin{array}{l}\text { Mixing } \\
\text { Speed } \\
\text { (rpm) }\end{array}$} & \multirow{2}{*}{$\begin{array}{c}\text { Reactor/ } \\
\text { Working } \\
\text { Volume (L) }\end{array}$} & \multirow{2}{*}{$\begin{array}{c}\text { Substrate } \\
\text { Loaded } \\
\text { (mmol/L) }\end{array}$} & \multirow[b]{2}{*}{$\begin{array}{l}\text { Operational } \\
\text { Parameter }\end{array}$} & \multirow{2}{*}{$\begin{array}{c}\text { Substrate } \\
\text { Consumed } \\
(\mathrm{mmol} / \mathrm{L})\end{array}$} & \multicolumn{5}{|c|}{ Products } & \multirow[b]{2}{*}{ Ref. } \\
\hline & & & & & & & & & $\underset{\text { yield }^{\mathrm{a}}}{\mathrm{H}_{2}}$ & $\mathrm{AA}(\mathrm{mmol} / \mathrm{L})$ & $\begin{array}{c}\text { LA } \\
(\mathrm{mmol} / \mathrm{L})\end{array}$ & $\underset{(\mathrm{mmol} / \mathrm{L})}{\mathrm{ALA}}$ & $\begin{array}{c}\text { But } \\
(\mathrm{mmol} / \mathrm{L})\end{array}$ & \\
\hline \multirow{4}{*}{$P_{\mathrm{H} 2}$ (mbar) } & \multirow{4}{*}{$\underset{\text { maritima }}{T .}$} & \multirow{4}{*}{80} & \multirow{4}{*}{ B } & \multirow{4}{*}{350} & \multirow{4}{*}{$1.4 / 0.1$} & \multirow{4}{*}{$\begin{array}{c}\text { Glucose } \\
\text { (28) }\end{array}$} & $P_{\mathrm{H} 2}=7.1 \pm 0.4$ & $19.8 \pm 1.1$ & 2.34 & $25.0 \pm 1.4$ & $10.5 \pm 0.5$ & & & \multirow{4}{*}{107} \\
\hline & & & & & & & $P_{\mathrm{H} 2}=71.4 \pm 2.1$ & $19.7 \pm 1.4$ & 2.44 & $24.6 \pm 2.4$ & $11.0 \pm 0.6$ & & & \\
\hline & & & & & & & $P_{\mathrm{H} 2}=178.5 \pm 3.5$ & $17.2 \pm 0.9$ & 2.32 & $20.1 \pm 1.0$ & $9.4 \pm 0.5$ & & & \\
\hline & & & & & & & $P_{\mathrm{H} 2}=606.9 \pm 18.7$ & $13.4 \pm 0.7$ & n. d. & $13.0 \pm 0.7$ & $11.0 \pm 0.6$ & & & \\
\hline \multirow{7}{*}{$\begin{array}{l}\text { Stirring } \\
\text { Speed } \\
\text { (rpm) }\end{array}$} & \multirow{3}{*}{$\begin{array}{c}T \\
\text { neapolitana }\end{array}$} & \multirow{3}{*}{75} & \multirow{3}{*}{ CSABR } & 300 & \multirow{3}{*}{$3.0 / 1.0$} & \multirow{3}{*}{$\begin{array}{c}\text { Xylose } \\
(33.3)\end{array}$} & 300 & 31.43 & $2.13 \pm 0.11$ & $41.8 \pm 2.16$ & $1.78 \pm 0.11$ & & & \multirow{3}{*}{113} \\
\hline & & & & 400 & & & 400 & 32.56 & $2.94 \pm 0.15$ & $50.12 \pm 2.5$ & $4.0 \pm 0.22$ & & & \\
\hline & & & & 600 & & & 600 & 31.87 & $2.24 \pm 0.11$ & $41.12 \pm 2.0$ & $1.89 \pm 0.11$ & & & \\
\hline & \multirow{4}{*}{$\begin{array}{c}T \\
\text { neapolitana } \\
\text { subsp. } \\
\text { capnolactica }\end{array}$} & \multirow{4}{*}{80} & \multirow{4}{*}{ CSTR } & 300 & & & 300 & $22.9 \pm 2.7$ & $3.0 \pm 0.0$ & $32.3 \pm 4.3$ & $10.0 \pm 1.0$ & $1.1 \pm 0.1$ & & \\
\hline & & & & 500 & $3.0 / 2.0$ & Glucose & 500 & $24.8 \pm 0.4$ & $3.2 \pm 0.1$ & $37.7 \pm 2.7$ & $8.1 \pm 0.2$ & $1.0 \pm 0.1$ & & [69] \\
\hline & & & & 300 & & & $300+\mathrm{GaR}$ & $24.7 \pm 0.2$ & $3.5 \pm 0.2$ & $39.2 \pm 1.2$ & $4.4 \pm 0.1$ & $0.9 \pm 0.0$ & & \\
\hline & & & & 500 & & & $500+\mathrm{GaR}$ & $24.9 \pm 0.2$ & $3.3 \pm 0.1$ & $38.7 \pm 2.2$ & $5.1 \pm 0.5$ & $0.8 \pm 0.0$ & & \\
\hline & & & & & & Glucose & $\mathrm{N}_{2}$ & $25.9 \pm 1.3$ & 2.8 & $44.8 \pm 5.4$ & $12.5 \pm 2.9$ & $1.3 \pm 0.4$ & & \\
\hline & & 80 & B & 250 & $3.8 / 1.0$ & $(28)$ & $\mathrm{CO}_{2}$ & $26.1 \pm 1.2$ & 2.8 & $35.6 \pm 5.8$ & $20.0 \pm 6.1$ & $2.7 \pm 0.5$ & & [31] \\
\hline & & 75 & SB & no & $0.12 / 0.04$ & Glycerol & $\mathrm{N}_{2}$ & $14 \pm 0.7$ & $2.06 \pm 0.09$ & $10.04 \pm 0.5$ & $0.34 \pm 0.02$ & & & [115] \\
\hline & & & & & & (108.6) & $\begin{array}{l}\mathrm{N}_{2} \text { plus } \mathrm{pH} \\
\text { control }\end{array}$ & $18 \pm 0.9$ & $1.98 \pm 0.1$ & $12.62 \pm 0.53$ & $0.25 \pm 0.01$ & & & \\
\hline & & & & & & Glucose & $\mathrm{w} / \mathrm{o}$ & - & $1.82 \pm 0.09$ & $64.28 \pm 2.83$ & & & $33.48 \pm 1.47$ & \\
\hline & $T$ & 77 & SB & 150 & $0.12 / 0.04$ & (39) & $\mathrm{N}_{2}$ & - & $3.24 \pm 0.14$ & $81.42 \pm 3.49$ & & & $36.77 \pm 2.04$ & [110] \\
\hline & & & & & & Xylose (27) & $\mathrm{w} / \mathrm{o}$ & - & $1.14 \pm 0.07$ & $40.30 \pm 3.5$ & & & $37.68 \pm 1.7$ & \\
\hline $\begin{array}{l}\text { Gas } \\
\text { sparging }\end{array}$ & & & & & & Aylose $(27)$ & $\mathrm{N}_{2}$ & - & $2.20 \pm 0.13$ & $71.94 \pm 3.66$ & & & $50.62 \pm 2.38$ & \\
\hline & $\begin{array}{c}T . \\
\text { neapolitana } \\
\text { subsp. }\end{array}$ & 80 & SB & no & $0.12 / 0.03$ & $\begin{array}{c}\text { Glucose } \\
(28)\end{array}$ & $\mathrm{N}_{2}$ & $25.7 \pm 0.1$ & $2.5 \pm 0.06$ & $27.3 \pm 0.8$ & $8.6 \pm 0.2$ & $2.5 \pm 0.2$ & & [70] \\
\hline & capnolactica & & & & & & $\mathrm{CO}_{2}$ & $28.3 \pm 1.0$ & $2.9 \pm 0.1$ & $22.1 \pm 0.9$ & $11.3 \pm 0.1$ & $3.0 \pm 0.3$ & & \\
\hline
\end{tabular}


Table 2. Cont

\begin{tabular}{|c|c|c|c|c|c|c|c|c|c|c|c|c|c|c|}
\hline \multirow{2}{*}{ Parameter } & \multirow{2}{*}{ Organism } & \multirow{2}{*}{$\mathrm{T}\left({ }^{\circ} \mathrm{C}\right)$} & \multirow{2}{*}{$\begin{array}{l}\text { Culture } \\
\text { Type }\end{array}$} & \multirow{2}{*}{$\begin{array}{l}\text { Mixing } \\
\text { Speed } \\
\text { (rpm) }\end{array}$} & \multirow{2}{*}{$\begin{array}{c}\text { Reactor/ } \\
\text { Working } \\
\text { Volume (L) }\end{array}$} & \multirow{2}{*}{$\begin{array}{c}\text { Substrate } \\
\text { Loaded } \\
(\mathrm{mmol} / \mathrm{L})\end{array}$} & \multirow{2}{*}{$\begin{array}{l}\text { Operational } \\
\text { Parameter }\end{array}$} & \multirow{2}{*}{$\begin{array}{c}\text { Substrate } \\
\text { Consumed } \\
\text { (mmol/L) }\end{array}$} & \multicolumn{5}{|c|}{ Products } & \multirow[b]{2}{*}{ Ref } \\
\hline & & & & & & & & & $\underset{\text { yield }^{\mathrm{a}}}{\mathrm{H}_{2}}$ & $\mathrm{AA}(\mathrm{mmol} / \mathrm{L})$ & $\underset{(\mathrm{mmol} / \mathrm{L})}{\text { LA }}$ & $\underset{(\mathrm{mmol} / \mathrm{L})}{\text { ALA }}$ & $\begin{array}{c}\text { But } \\
(\mathrm{mmol} / \mathrm{L})\end{array}$ & \\
\hline & \multirow{2}{*}{$\begin{array}{c}T . \\
\text { neapolitana }\end{array}$} & \multirow{2}{*}{80} & \multirow{2}{*}{ SB } & \multirow{2}{*}{ no } & \multirow{2}{*}{$0.12 / 0.03$} & \multirow{2}{*}{$\begin{array}{c}\text { Glucose } \\
(28)\end{array}$} & $\mathrm{N}_{2}$ & $21.7 \pm 0.6$ & $2.5 \pm 0.03$ & $30.2 \pm 0.4$ & $2.2 \pm 0.02$ & $1.9 \pm 0.3$ & & \\
\hline & & & & & & & $\mathrm{CO}_{2}$ & $20.8 \pm 2.3$ & $1.9 \pm 0.1$ & $20.8 \pm 0.1$ & $1.2 \pm 0.06$ & $2.4 \pm 0.3$ & & \\
\hline & \multirow{2}{*}{$\underset{\text { maritima }}{T .}$} & \multirow{2}{*}{80} & \multirow{2}{*}{ SB } & \multirow{2}{*}{ no } & \multirow{2}{*}{$0.12 / 0.03$} & \multirow{2}{*}{$\begin{array}{c}\text { Glucose } \\
(28)\end{array}$} & $\mathrm{N}_{2}$ & $23.2 \pm 1.0$ & $1.9 \pm 0.06$ & $25.5 \pm 0.5$ & $5.3 \pm 0.8$ & $2.4 \pm 0.06$ & & \\
\hline & & & & & & & $\mathrm{CO}_{2}$ & $19.9 \pm 0.6$ & $2.0 \pm 0.1$ & $18.3 \pm 0.3$ & $1.6 \pm 0.2$ & $2.3 \pm 0.3$ & & \\
\hline & \multirow{2}{*}{$\begin{array}{c}T . \\
\text { naphtophila }\end{array}$} & \multirow{2}{*}{80} & \multirow{2}{*}{ SB } & \multirow{2}{*}{ no } & \multirow{2}{*}{$0.12 / 0.04$} & Glucose & $\mathrm{N}_{2}$ & $13.30 \pm 1.10$ & $2.20 \pm 0.20$ & $15.70 \pm 0.10$ & $1.40 \pm 0.06$ & $0.80 \pm 0.10$ & & \\
\hline & & & & & & $(28)$ & $\mathrm{CO}_{2}$ & $20.80 \pm 1.70$ & $1.60 \pm 0.20$ & $19.20 \pm 0.10$ & $5.00 \pm 0.02$ & $1.80 \pm 0.05$ & & \\
\hline & $T$. & 80 & SB & no & $0.12 / 0.05$ & Glucose & $\mathrm{N}_{2}$ & $9.20 \pm 1.30$ & $3.00 \pm 0.40$ & $13.10 \pm 0.05$ & $2.00 \pm 0.01$ & 0.00 & & \\
\hline & & & & & & & $\mathrm{CO}_{2}$ & $14.20 \pm 0.60$ & $1.90 \pm 0.10$ & $12.60 \pm 0.10$ & $3.80 \pm 0.02$ & $0.30 \pm 0.10$ & & \\
\hline & $T$. & 70 & SB & no & $0.12 / 0.05$ & Glucose & $\mathrm{N}_{2}$ & $10.90 \pm 1.10$ & $2.60 \pm 0.10$ & $16.70 \pm 3.60$ & $2.20 \pm 0.50$ & $3.20 \pm 0.90$ & & \\
\hline & & & & & & & $\mathrm{CO}_{2}$ & $15.20 \pm 0.90$ & $1.80 \pm 0.03$ & $15.60 \pm 1.50$ & $2.30 \pm 0.40$ & $6.60 \pm 0.70$ & & \\
\hline & $T$. & 60 & SB & no & $0.12 / 0.05$ & Glucose & $\mathrm{N}_{2}$ & $18.10 \pm 0.40$ & $1.50 \pm 0.20$ & $15.90 \pm 0.40$ & $5.70 \pm 0.10$ & $1.40 \pm 0.06$ & & \\
\hline & profunda & 00 & SD & 100 & $0.12 / 0.00$ & $(28)$ & $\mathrm{CO}_{2}$ & $22.60 \pm 1.70$ & $0.70 \pm 0.04$ & $5.60 \pm 0.20$ & $2.3 \pm 0.04$ & $2.60 \pm 0.30$ & & \\
\hline & Pseudot. & 70 & SB & no & $0.12 / 0.05$ & Glucose & $\mathrm{N}_{2}$ & $8.80 \pm 1.10$ & $1.10 \pm 0.30$ & $6.40 \pm 0.10$ & $0.10 \pm 0.00$ & $2.90 \pm 0.10$ & & \\
\hline & hypogea & & & & & (28) & $\mathrm{CO}_{2}$ & $4.30 \pm 0.10$ & $0.50 \pm 0.10$ & $3.10 \pm 0.20$ & $0.10 \pm 0.00$ & $3.40 \pm 0.30$ & & \\
\hline & & 10 & SD & 100 & $0.12 / 0.00$ & $(28)$ & $\mathrm{CO}_{2}$ & $6.70 \pm 0.20$ & $2.10 \pm 0.10$ & $7.80 \pm 0.30$ & $0.10 \pm 0.01$ & $10.0 \pm 0.30$ & & \\
\hline & Pseudot. & 70 & SB & no & $0.12 / 0.05$ & Glucose & $\mathrm{N}_{2}$ & $9.30 \pm 0.50$ & $1.20 \pm 0.10$ & $5.10 \pm 0.05$ & $0.20 \pm 0.00$ & $2.70 \pm 0.05$ & & \\
\hline & lettingae & & & & & & $\mathrm{CO}_{2}$ & $8.10 \pm 0.70$ & $1.30 \pm 0.30$ & $4.40 \pm 0.10$ & $0.05 \pm 0.01$ & $3.70 \pm 0.20$ & & {$[70]$} \\
\hline & Pseudot. & 70 & $\mathrm{SB}$ & no & $012 / 005$ & Glucose & $\mathrm{N}_{2}$ & $23.10 \pm 2.10$ & $1.80 \pm 0.20$ & $30.60 \pm 6.90$ & $16.20 \pm 4.60$ & $9.50 \pm 0.40$ & & \\
\hline $\begin{array}{c}\text { Gas } \\
\text { sparoing }\end{array}$ & subterranea & 10 & SB & no & $0.12 / 0.05$ & (28) & $\mathrm{CO}_{2}$ & $27.00 \pm 1.40$ & $1.40 \pm 0.10$ & $31.90 \pm 7.90$ & $10.70 \pm 4.0$ & $20.0 \pm 8.0$ & & \\
\hline sparging & Pseudot. & 80 & SB & no & $012 / 005$ & Glucose & $\mathrm{N}_{2}$ & Complete & $1.8 \pm 0.02$ & $30.00 \pm 2.20$ & $6.50 \pm 0.20$ & $1.10 \pm 0.07$ & & \\
\hline & thermarum & & & & & (28) & $\mathrm{CO}_{2}$ & Complete & $1.50 \pm 0.10$ & $24.80 \pm 0.70$ & $5.60 \pm 0.60$ & $2.20 \pm 0.20$ & & \\
\hline & & & & & & & 0.46 & $3.2 \pm 0.04$ & 2.39 & $34.3 \pm 0.6$ & $10.9 \pm 0.4$ & & & \\
\hline Biomass & $T$ & 80 & Flask & 300 & $0.25 / 0.2$ & Glucose & 0.91 & $2.9 \pm 0.06$ & 2.44 & $32.9 \pm 0.8$ & $12.2 \pm 0.8$ & & & {$[68]$} \\
\hline & & & & & & & 1.33 & $3.4 \pm 0.01$ & 2.58 & $32.3 \pm 0.2$ & $11.5 \pm 0.5$ & & & {$[68]$} \\
\hline & & & & & & & 1.74 & $3.0 \pm 0.04$ & 2.37 & $31.4 \pm 1.1$ & $14.7 \pm 0.7$ & & & \\
\hline
\end{tabular}


Table 2. Cont.

\begin{tabular}{|c|c|c|c|c|c|c|c|c|c|c|c|c|c|c|}
\hline \multirow{2}{*}{ Parameter } & \multirow{2}{*}{ Organism } & \multirow{2}{*}{$\mathrm{T}\left({ }^{\circ} \mathrm{C}\right)$} & \multirow{2}{*}{$\begin{array}{l}\text { Culture } \\
\text { Type }\end{array}$} & \multirow{2}{*}{$\begin{array}{l}\text { Mixing } \\
\text { Speed } \\
\text { (rpm) }\end{array}$} & \multirow{2}{*}{$\begin{array}{c}\text { Reactor/ } \\
\text { Working } \\
\text { Volume (L) }\end{array}$} & \multirow{2}{*}{$\begin{array}{c}\text { Substrate } \\
\text { Loaded } \\
(\mathrm{mmol} / \mathrm{L})\end{array}$} & \multirow{2}{*}{$\begin{array}{l}\text { Operational } \\
\text { Parameter }\end{array}$} & \multirow{2}{*}{$\begin{array}{c}\text { Substrate } \\
\text { Consumed } \\
(\mathrm{mmol} / \mathrm{L})\end{array}$} & \multicolumn{5}{|c|}{ Products } & \multirow[b]{2}{*}{ Ref. } \\
\hline & & & & & & & & & $\underset{\text { yield }^{\mathrm{a}}}{\mathrm{H}_{2}}$ & $\mathrm{AA}(\mathrm{mmol} / \mathrm{L})$ & $\begin{array}{c}\text { LA } \\
(\mathrm{mmol} / \mathrm{L})\end{array}$ & $\underset{(\mathrm{mmol} / \mathrm{L})}{\text { ALA }}$ & $\begin{array}{c}\text { But } \\
(\mathrm{mmol} / \mathrm{L})\end{array}$ & \\
\hline \multirow{10}{*}{$\mathrm{pH}$} & \multirow{6}{*}{$\begin{array}{c}T . \\
\text { neapolitana } \\
\text { subsp. } \\
\text { capnolactica }\end{array}$} & \multirow{6}{*}{80} & \multirow{6}{*}{ SB } & \multirow{6}{*}{ no } & \multirow{6}{*}{$0.12 / 0.03$} & \multirow{6}{*}{$\begin{array}{c}\text { Glucose } \\
(28)\end{array}$} & $\mathrm{w} / \mathrm{o}$ & $18.54 \pm 0.15$ & $1.78 \pm 0.29$ & $22.76 \pm 0.40$ & $11.35 \pm 0.62$ & & & \multirow{6}{*}{ [67] } \\
\hline & & & & & & & 0.01M MOPS & $26.42 \pm 0.05$ & $3.27 \pm 0.18$ & $26.65 \pm 0.87$ & $14.23 \pm 0.22$ & & & \\
\hline & & & & & & & 0.01M TRIS & $25.55 \pm 0.06$ & $3.10 \pm 0.10$ & $26.77 \pm 0.29$ & $12.08 \pm 0.89$ & & & \\
\hline & & & & & & & 0.01M HEPES & $25.99 \pm 0.03$ & $2.85 \pm 0.40$ & $25.56 \pm 0.49$ & $13.58 \pm 0.88$ & & & \\
\hline & & & & & & & $0.01 \mathrm{M} \mathrm{HCO}_{3}^{-}$ & $25.62 \pm 0.10$ & $2.20 \pm 0.30$ & $22.82 \pm 0.84$ & $14.63 \pm 3.23$ & & & \\
\hline & & & & & & & 0.01M phosphate & $26.17 \pm 0.26$ & $2.78 \pm 0.40$ & $24.70 \pm 0.59$ & $14.92 \pm 0.25$ & & & \\
\hline & \multirow{4}{*}{$\begin{array}{c}T \\
\text { neapolitana }\end{array}$} & \multirow{4}{*}{75} & \multirow{4}{*}{ CSABR } & \multirow{4}{*}{300} & \multirow{4}{*}{$3.0 / 1.0$} & \multirow{2}{*}{$\begin{array}{c}\text { Glucose } \\
(28)\end{array}$} & w/o pH control & $21.98 \pm 1.11$ & $2.05 \pm 0.1$ & $30.81 \pm 1.5$ & $3.33 \pm 0.22$ & & & \multirow{4}{*}{ [113] } \\
\hline & & & & & & & plus $\mathrm{pH}$ control & $27.47 \pm 1.39$ & $3.2 \pm 0.16$ & $38.3 \pm 2.0$ & $1.77 \pm 0.11$ & & & \\
\hline & & & & & & \multirow{2}{*}{$\begin{array}{c}\text { Xylose } \\
(33.3)\end{array}$} & w/o pH control & $29.77 \pm 1.46$ & $1.84 \pm 0.09$ & $34.47 \pm 1.66$ & $3.77 \pm 0.22$ & & & \\
\hline & & & & & & & plus $\mathrm{pH}$ control & $31.83 \pm 1.6$ & $2.22 \pm 0.11$ & $41.8 \pm 2.0$ & $1.66 \pm 0.11$ & & & \\
\hline \multirow{7}{*}{$\mathrm{pH}$} & \multirow{7}{*}{$\begin{array}{c}T . \\
\text { neapolitana }\end{array}$} & & & & & Sucrose & w/o pH control & $13.78 \pm 0.7$ & $3.52 \pm 0.18$ & $33.13 \pm 1.65$ & $3.11 \pm 0.11$ & & & \\
\hline & & & & & & $(14.6)$ & plus $\mathrm{pH}$ control & $14.69 \pm 0.06$ & $4.95 \pm 0.25$ & $35.47 \pm 1.83$ & $2.11 \pm 0.11$ & & & \\
\hline & & & & & $30 / 10$ & & w/o pH control & 29.44 & $1.85 \pm 0.09$ & $34.97 \pm 1.66$ & $3.88 \pm 0.22$ & & & [113] \\
\hline & & 75 & CSABR & 300 & $3.0 / 1.0$ & Xylose & $\mathrm{pH}=6.5$ & 32.57 & $2.71 \pm 0.14$ & $49.62 \pm 2.50$ & $3.44 \pm 0.11$ & & & \\
\hline & & & & & & & $\mathrm{pH}=7.5$ & 31.77 & $2.23 \pm 0.11$ & $41.96 \pm 2.16$ & $1.89 \pm 0.11$ & & & \\
\hline & & 75 & $\mathrm{SB}$ & no & & Glycerol & w/o HEPES & $16.96 \pm 0.8$ & $1.23 \pm 0.06$ & $9.14 \pm 0.45$ & & & & \\
\hline & & 75 & SB & no & $0.04 / 0.12$ & (108.6) & 0.05 M HEPES & $28.26 \pm 1.4$ & $2.73 \pm 0.14$ & $22.35 \pm 1.05$ & & & & [116] \\
\hline & & & & & & & w/o $\mathrm{NaHCO}_{3}$ & $25.9 \pm 1.3$ & 2.8 & $44.5 \pm 5.4$ & $12.5 \pm 2.69$ & & & \\
\hline & & & & & 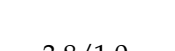 & Glucose & $\mathrm{NaHCO}_{3} 14 \mathrm{mM}$ & $25.4 \pm 2.1$ & 1.7 & $30.5 \pm 4.9$ & $18.0 \pm 0.6$ & & & [01 \\
\hline & $\begin{array}{c}T . \\
\text { neanolitana }\end{array}$ & 80 & B & 250 & $3.8 / 1.0$ & (28) & $\mathrm{NaHCO}_{3} 20 \mathrm{mM}$ & $23.2 \pm 1.9$ & 1.0 & $44.4 \pm 8.2$ & $9.2 \pm 2.7$ & & & [31] \\
\hline $\mathrm{pH}$ & & & & & & & $\mathrm{NaHCO}_{3} 40 \mathrm{mM}$ & $6.2 \pm 0.8$ & 2.7 & $18.0 \pm 4.3$ & $0.7 \pm 1.5$ & & & \\
\hline & & 75 & $P$ & $n$ & 12 12 1 & Glycerol & $\mathrm{w} / \mathrm{o}$ IA & - & $438 \pm 22^{b}$ & $7.49 \pm 0.33$ & $3.55 \pm 0.22 *$ & & & [1201 \\
\hline & & 75 & B & no & $0.12 / 0.04$ & (108.6) & $1.5 \mathrm{~g} / \mathrm{L} \mathrm{IA}$ & - & $619 \pm 30^{b}$ & $11.49 \pm 0.5$ & $1.66 \pm 0.0^{*}$ & & & [122] \\
\hline
\end{tabular}


Table 2. Cont

\begin{tabular}{|c|c|c|c|c|c|c|c|c|c|c|c|c|c|c|}
\hline \multirow[b]{2}{*}{ Parameter } & \multirow{2}{*}{ Organism } & \multirow{2}{*}{$\mathrm{T}\left({ }^{\circ} \mathrm{C}\right)$} & \multirow{2}{*}{$\begin{array}{l}\text { Culture } \\
\text { Type }\end{array}$} & \multirow{2}{*}{$\begin{array}{l}\text { Mixing } \\
\text { Speed } \\
\text { (rpm) }\end{array}$} & \multirow{2}{*}{$\begin{array}{c}\text { Reactor/ } \\
\text { Working } \\
\text { Volume (L) }\end{array}$} & \multirow{2}{*}{$\begin{array}{c}\text { Substrate } \\
\text { Loaded } \\
(\mathrm{mmol} / \mathrm{L})\end{array}$} & \multirow{2}{*}{$\begin{array}{l}\text { Operational } \\
\text { Parameter }\end{array}$} & \multirow{2}{*}{$\begin{array}{c}\text { Substrate } \\
\text { Consumed } \\
(\mathrm{mmol} / \mathrm{L})\end{array}$} & \multicolumn{5}{|c|}{ Products } & \multirow[b]{2}{*}{ Ref. } \\
\hline & & & & & & & & & $\underset{\text { yield }^{\mathrm{a}}}{\mathrm{H}_{2}}$ & AA (mmol/L) & $\begin{array}{c}\text { LA } \\
(\mathrm{mmol} / \mathrm{L})\end{array}$ & $\underset{(\mathrm{mmol} / \mathrm{L})}{\text { ALA }}$ & $\begin{array}{c}\text { But } \\
(\mathrm{mmol} / \mathrm{L})\end{array}$ & \\
\hline \multirow{4}{*}{$\begin{array}{l}\text { Temp. } \\
\left({ }^{\circ} \mathrm{C}\right)\end{array}$} & \multirow{4}{*}{$\begin{array}{c}T \\
\text { neapolitana }\end{array}$} & 60 & \multirow{4}{*}{ SB } & \multirow{4}{*}{75} & \multirow{4}{*}{$0.26 / 0.05$} & \multirow{4}{*}{$\begin{array}{c}\text { Glucose } \\
(14)\end{array}$} & 60 & $2.2 *$ & $2.04 \pm 0.05$ & 2.0 & n. $d$ & & & \multirow{4}{*}{ [65] } \\
\hline & & 70 & & & & & 70 & $8.5^{*}$ & $3.18 \pm 0.02$ & 11.5 & 0.45 & & & \\
\hline & & 77 & & & & & 77 & $11.0 \pm 0.5^{*}$ & $3.85 \pm 0.28$ & 16.5 & $0.85 \pm 0.1$ & & & \\
\hline & & 85 & & & & & 85 & $11.0 \pm 0.5^{*}$ & $3.75 \pm 0.49$ & $18.0 \pm 1.0$ & $1.25 \pm 0.05$ & & & \\
\hline \multirow{2}{*}{ Oxygen } & \multirow{2}{*}{$\underset{\text { maritima }}{T}$} & \multirow{2}{*}{80} & \multirow{2}{*}{ B } & \multirow{2}{*}{150} & \multirow{2}{*}{$2.30 / 1.53$} & \multirow{2}{*}{$\begin{array}{c}\text { Glucose } \\
(20)\end{array}$} & $\mathrm{w} / \mathrm{oO} \mathrm{O}_{2}$ & 17.41 & $38.09^{b}$ & 18.05 & 4.36 & $1.60 \pm 0.2$ & & \multirow{2}{*}{ [129] } \\
\hline & & & & & & & with $\mathrm{O}_{2}$ & 19.30 & $31.75^{b}$ & 18.27 & 5.45 & $1.30 \pm 0.2$ & & \\
\hline
\end{tabular}




\section{Nitrogen Containing-Compounds}

Nitrogen sources ( $\mathrm{N}$-sources) are essential for bacterial life for the synthesis of cellular components like nucleic acids, proteins, and enzymes [133,134]. Yeast extract (YE), tryptone, and ammonium chloride $\left(\mathrm{NH}_{4} \mathrm{Cl}\right)$ have been identified as highly efficient and versatile organic $\mathrm{N}$-sources in laboratory practices. It is widely demonstrated that most of the Thermotogae members can use yeast extract and tryptone to grow and metabolize carbohydrates $[1,10,77,108,135,136]$.

Numerous efforts were made to replace YE by combining casamino acids and amino acids, but Pseudot. elfii failed to grow on these alternative substrates. The biogas yields of cultures grown with other N-sources were about 4-14\% of those with YE (Table 3) [108].

Experiments with different concentrations of $\mathrm{YE}$ and tryptone were performed to identify their optimal and minimal concentrations in growth media $[64,108,122,137,138]$. YE and tryptone are sufficient to ensure growth and hydrogen production without additional carbon sources in Pseudot. elfii (Table 3) [108]. van Niel et al. [108] used media with various concentrations of YE and tryptone to ferment glucose by Pseudot. elfii [108]. They discovered that increasing the contents of both YE and tryptone from $2 \mathrm{~g} / \mathrm{L}$ to $5 \mathrm{~g} / \mathrm{L}$ improved $\mathrm{H}_{2}$ production (14.8 vs. $28.8 \mathrm{mmol} / \mathrm{L})$ but higher contents did not further improve hydrogen and acetic acid production; high levels of both YE and tryptone only increased acetic acid production in medium lacking other C-sources [108].

When there was a low level of YE $(2 \mathrm{~g} / \mathrm{L})$ but no tryptone, productions of $\mathrm{H}_{2}$ and acetic acid remained low, suggesting that tryptone served as an energy source like YE (Table 3) [108]. Although the amino acid compositions of the two N-sources are fairly similar, tryptone contains abundant peptides, a preferred form of amino acids by many bacteria [138]. In another study [122], T. neapolitana biomass increased along with the increase of YE concentrations in the range of 1.0-4.0 g/L but not with higher YE concentrations (5.0-6.0 g/L) [122]. The $\mathrm{H}_{2}$ production plateaued at $420 \mathrm{~mL} / \mathrm{L}$ in T. neapolitana growing on glycerol with 1.0-4.0 g/L YE [122]. Experiments in T. maritima and T. neapolitana revealed that with over $2 \mathrm{~g} / \mathrm{L}$ YE, there was a clear increase of acetic acid production, and hydrogen counted up to $30-33 \%$ of the total gas in the headspace, even though a mild reduction in glucose consumption occurred (Table 3) [64,138].

Nevertheless, low concentrations (2-4 g/L) of YE are still able to support productivity and bacterial growth $[64,108,122,138]$. d'Ippolito et al. [30] reported that $2 \mathrm{~g} / \mathrm{L}$ of both tryptone and YE contributed to 10-15\% of the total fermentation products in T. neapolitana [30]. Balk et al. [75] demonstrated that Pseudot. lettingae was able to degrade methanol in around 30 days in the presence of $0.5 \mathrm{~g} / \mathrm{L} \mathrm{YE}$, whereas the substrate degradation did not occur when YE was omitted [75]. In contrast, the fermentation of T. neapolitana with glucose occurred in a medium without YE, even though the total glucose consumption without YE was attained in $30 \mathrm{~h}$ rather than $12 \mathrm{~h} . \mathrm{H}_{2}$ and acetate amounts were half in the medium without YE, (Table 3) [135].

The impact of an inorganic $\mathrm{N}$-source on Thermotogae fermentation, such as $\mathrm{NH}_{4} \mathrm{Cl}$, has not been extensively studied, but the presence of $\mathrm{NH}_{4} \mathrm{Cl}$ has often been associated with either exopolysaccharide (EPS) formation in T. maritima or alanine production in T. neapolitana $[62,129,136,139]$. It is not clear how $\mathrm{NH}_{4} \mathrm{Cl}$ stimulates EPS production, but it might involve processing the surplus of reducing equivalents. For example, some organisms produce EPS as a mechanism to transport reducing equivalents out of the cell [140].

Han and $\mathrm{Xu}$ [61] demonstrated that a surplus of $\mathrm{NH}_{4} \mathrm{Cl}$ could partially substitute $\mathrm{YE}$ and tryptone in an optimized medium for auxotrophic Thermotoga sp. $R Q 7$ strain [61].

\section{Sodium Chloride and Phosphate}

All members of the phylum Thermotogae showed great adaptability to a wide range of salinity levels (Table 1), although the optimal concentrations of $\mathrm{NaCl}$ vary among the members. Geotoga, Oceanotoga, and Petrotoga species can survive in environments comprised of $10 \% \mathrm{NaCl}$, while P. mexicana can live in up to $20 \% \mathrm{NaCl}$ (Table 1 ) $[10,12,95]$. 
In contrast, species of the genus Fervidobacterium can tolerate salt concentrations up to $1 \%[5,79-81,83]$. Among the species of the genus Mesotoga, Ms. infera exhibited the lowest tolerance of $\mathrm{NaCl}$ (Table 1).

$\mathrm{NaCl}$ at $20 \mathrm{~g} / \mathrm{L}$ was reported to be optimal for T. neapolitana growing on either glucose or glycerol when hydrogen production is concerned $[64,105,106,108,110,116]$. Recently, the effect of different $\mathrm{NaCl}$ concentrations $(0-35 \mathrm{~g} / \mathrm{L})$ on the CLF process was explored in T. neapolitana subs. capnolactica using glucose as the carbon source [67]. $\mathrm{H}_{2}$ synthesis and biomass growth were reduced by $15 \%$ and $25 \%$, respectively, when $\mathrm{NaCl}$ was increased to $35 \mathrm{~g} / \mathrm{L}$ (Table 3). Similarly, acetic acid production decreased from $26.1 \pm 4.7 \mathrm{mM}$ with $10 \mathrm{~g} / \mathrm{L} \mathrm{NaCl}$ to $23.2 \pm 0.8 \mathrm{mM}$ with $35 \mathrm{~g} / \mathrm{L} \mathrm{NaCl}$. In contrast, high $\mathrm{NaCl}$ levels had a positive impact on lactic acid production, which increased 7.5-fold $(2.8 \pm 0.3 \mathrm{mM}$ at $0 \mathrm{~g} / \mathrm{L}$ $\mathrm{NaCl}$ vs. $21.6 \pm 6.2 \mathrm{mM}$ at $35 \mathrm{~g} / \mathrm{L} \mathrm{NaCl}$ ), without affecting the overall $\mathrm{H}_{2}$ yields (Table 3) [67]. Pradhan and coworkers [67] suggested a possible involvement of $\mathrm{NaCl}$ in a sodium ion gradient that potentially fuels ATP synthesis and transport processes [67]. This creates a bioenergetic balance and supplies necessary reducing equivalents to convert acetic acid into lactic acid under CLF conditions (Figure 1) [67,118,119]. Similarly, another study [141] on $\mathrm{H}_{2}$-producing Vibrionaceae showed that increasing $\mathrm{NaCl}$ levels from 9 to $75 \mathrm{~g} / \mathrm{L}$ enhanced lactic acid synthesis [141].

Regarding phosphate species, they have a strong buffering ability to mitigate $\mathrm{pH}$ fluctuation caused by the accumulation of volatile fatty acids [142]. Phosphate deficiency induced an increase in lactic acid production and a small decrease in $\mathrm{H}_{2}$ formation, suggesting a slight shift of the T. maritima metabolism towards lactic acid production. Besides its role as a macro-element, phosphate can also interact with calcium, favoring $\mathrm{H}_{2}$ production [141,143]. Saidi and co-workers [52] showed that T. maritima struggled to produce $\mathrm{H}_{2}$ at the same rate when there was an oversupply of calcium but an undersupply of phosphate in the medium [52]. For unknown reasons, phosphate exceeding $50 \mathrm{mM}$ has been suggested to inhibit Pseudot. elfii growth [108]. 


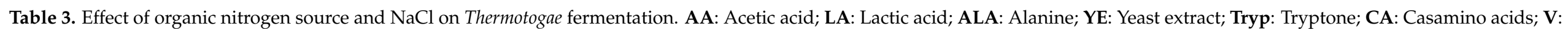

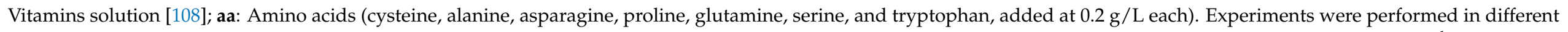

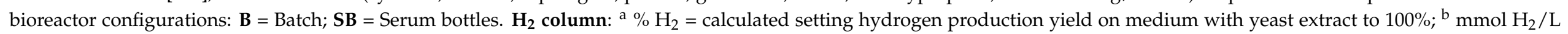
medium; ${ }^{\mathrm{C}} \mathrm{mL} \mathrm{H}_{2} / \mathrm{L}$ culture; ${ }^{\mathrm{d}} \mathrm{mol} \mathrm{H}_{2} / \mathrm{mol}$ glucose. ${ }^{*}$ Values extrapolated from the graphical representation of data.

\begin{tabular}{|c|c|c|c|c|c|c|c|c|c|c|c|c|c|}
\hline \multirow{2}{*}{ Parameter } & \multirow{2}{*}{ Organism } & \multirow{2}{*}{$\mathrm{T}\left({ }^{\circ} \mathrm{C}\right)$} & \multirow{2}{*}{$\begin{array}{l}\text { Culture } \\
\text { Type }\end{array}$} & \multirow{2}{*}{$\begin{array}{c}\text { Mixing } \\
\text { Speed } \\
\text { (rpm) }\end{array}$} & \multirow{2}{*}{$\begin{array}{c}\text { Reactor/ } \\
\text { Working } \\
\text { Volume (L) }\end{array}$} & \multirow{2}{*}{$\begin{array}{l}\text { Substrate Loaded } \\
(\mathrm{mmol} / \mathrm{L})\end{array}$} & \multirow{2}{*}{$\begin{array}{l}\text { Operational } \\
\text { Parameter }\end{array}$} & \multirow{2}{*}{$\begin{array}{c}\text { Substrate } \\
\text { Consumed } \\
(\mathrm{mmol} / \mathrm{L})\end{array}$} & \multicolumn{4}{|c|}{ Products } & \multirow{2}{*}{ Ref. } \\
\hline & & & & & & & & & $\mathbf{H}_{2}$ & $\begin{array}{c}\mathrm{AA} \\
(\mathrm{mmol} / \mathrm{L})\end{array}$ & $\begin{array}{c}\text { LA } \\
(\mathrm{mmol} / \mathrm{L})\end{array}$ & $\begin{array}{c}\text { ALA } \\
(\mathrm{mmol} / \mathrm{L})\end{array}$ & \\
\hline \multirow{21}{*}{$\begin{array}{l}\text { Nitrogen } \\
\text { sources } \\
(\mathrm{g} / \mathrm{L})\end{array}$} & \multirow{13}{*}{$\begin{array}{c}\text { Pseudot. } \\
\text { elfii }\end{array}$} & \multirow{3}{*}{65} & \multirow{3}{*}{ B } & \multirow{3}{*}{100} & \multirow{3}{*}{$3.0 / 1.0$} & \multirow{3}{*}{ no } & $\mathrm{w} / \mathrm{o} Y \mathrm{YE}$ & - & $40^{\mathrm{a}}$ & & & & \multirow{13}{*}{108} \\
\hline & & & & & & & $\mathrm{CA}+\mathrm{V}$ & - & $4^{\mathrm{a}}$ & & & & \\
\hline & & & & & & & $\mathrm{CA}+\mathrm{V}+\mathrm{aa}$ & - & $6^{a}$ & & & & \\
\hline & & \multirow{3}{*}{65} & \multirow{3}{*}{ B } & \multirow{3}{*}{100} & \multirow{3}{*}{$3.0 / 1.0$} & \multirow{3}{*}{ Glucose (22.4) } & YE (5) & n.d. & $100^{\mathrm{a}}$ & & & & \\
\hline & & & & & & & $\mathrm{CA}+\mathrm{V}$ & n.d. & $14^{\mathrm{a}}$ & & & & \\
\hline & & & & & & & $\mathrm{CA}+\mathrm{V}+\mathrm{aa}$ & n.d. & $14^{\mathrm{a}}$ & & & & \\
\hline & & \multirow{4}{*}{65} & \multirow{4}{*}{ B } & \multirow{4}{*}{100} & \multirow{4}{*}{$3.0 / 1.0$} & & YE (2) -Tryp (0) & - & $13.9^{\mathrm{b}}$ & 3.5 & & & \\
\hline & & & & & & no & YE (2) -Tryp (2) & - & $14.8^{\mathrm{b}}$ & 3.4 & & & \\
\hline & & & & & & & YE (5) -Tryp (0) & - & $14.0^{\mathrm{b}}$ & 0.0 & & & \\
\hline & & & & & & & YE (5) -Tryp (5) & - & $28.8^{\mathrm{b}}$ & 4.9 & & & \\
\hline & & & & & & & YE (2) -Tryp (0) & 10.3 & $25.8^{\mathrm{b}}$ & 10.7 & & & \\
\hline & & 65 & $B$ & 100 & $30 / 10$ & Glucose (56) & YE (2) -Tryp (2) & 18.3 & $78.5^{\mathrm{b}}$ & 19.7 & & & \\
\hline & & 60 & B & 100 & $3.0 / 1.0$ & Giucose (כo) & YE (5) -Tryp (0) & 13.1 & $84.9^{b}$ & 26.3 & & & \\
\hline & & & & & & & YE (0.5) & $26.6^{*}$ & $260 * c$ & $15^{*}$ & & & \\
\hline & & & & & & & YE (1.0) & $26^{*}$ & $320 * c$ & $22.5^{*}$ & & & \\
\hline & $\begin{array}{c}\text { T. } \\
\text { neapolitana }\end{array}$ & 80 & SB & no & $0.12 / 0.05$ & Glucose (28) & YE (2.0) & $25.5^{*}$ & $360 * c$ & $26.6^{*}$ & & & \\
\hline & & & & & & & YE (4.0) & $25^{*}$ & $430 * c$ & $30 *$ & & & {$[64]$} \\
\hline & & & & & & & YE (6.0) & $25^{*}$ & $430 * c$ & $33.3 *$ & & & {$[07]$} \\
\hline & & & & & & & YE (0.5) & $25.5^{*}$ & $190 * c$ & $0.0^{*}$ & & & \\
\hline & $\underset{\text { maritima }}{T .}$ & 80 & SB & no & $0.12 / 0.05$ & Glucose (28.00) & YE (1.0) & $25^{*}$ & $260 * c$ & $20.8^{*}$ & & & \\
\hline & & & & & & & YE (2.0) & $25^{*}$ & $270 * \mathrm{c}$ & $23 *$ & & & \\
\hline & & & & & & & YE (4.0) & $25 *$ & $335 * c$ & $27.5^{*}$ & & & [64] \\
\hline Nitrogen & maritima & 80 & SB & no & $0.12 / 0.05$ & Glucose $(28.00)$ & YE (6.0) & $24 *$ & $390 * c$ & $28^{*}$ & & & \\
\hline $\begin{array}{l}\text { sourres } \\
\text { (g/L) }\end{array}$ & T. & 77 & $\mathrm{R}$ & 75 & $012 / 005$ & $C l u \cos (28)$ & no YE & $23 *$ & $9 * b$ & $4.2 *$ & & & [136] \\
\hline & neapolitana & 17 & D & 70 & $0.12 / 0.05$ & Glucose (28) & YE (0.5) & Completed * & $16^{* b}$ & $7.2 *$ & & & \\
\hline
\end{tabular}


Table 3. Cont.

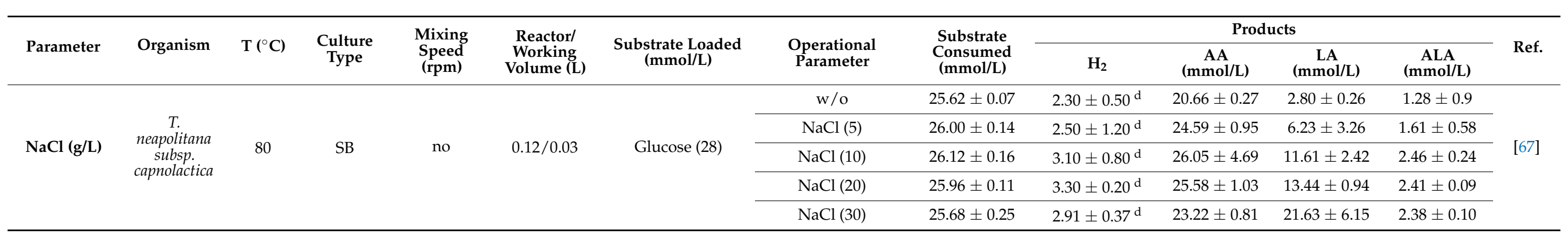




\section{Sulfur-Containing Compounds}

All members of the phylum Thermotogae reduced sulfur-containing compounds such as elemental sulfur $\left(\mathrm{S}^{0}\right)$, thiosulfate (Thio), and polysulfide to hydrogen sulfide $\left(\mathrm{H}_{2} \mathrm{~S}\right)$, which is produced at the expense of $\mathrm{H}_{2}$ (Table 1 ) $[1,4,29,76,144,145]$. Sufficient supply of sulfurcontaining compounds seems to be critically important; due to a large requirement for Fe-S clusters by the hydrogenase (containing 20 atoms of Fe and 18 atoms of S), PFOR, and other enzymes (Figure 1) [123,146]. In the literature, the effect of sulfur sources has been widely explored. The reduction of S-sources is considered an electron-sink reaction to deplete the surplus of electron power $[3,98,107,147]$. It is well known that the growth of most anaerobic bacteria of the phylum Thermotogae is stimulated by S-sources, but not dependent on them $[1,29,52,53,75,107,125,126,144]$. Generally speaking, the substrate consumption rate is benefited from a sulfur supply in the medium, except for the methanol fermentation in Pseudot. lettingae, which is reduced by S-containing compounds $(19.7 \mathrm{mmol} / \mathrm{L} \mathrm{w} / \mathrm{o} \mathrm{S}$-source, $18.7 \mathrm{mmol} / \mathrm{L}$ with Thio and $10.6 \mathrm{mmol} / \mathrm{L}$ with $\mathrm{S}^{0}$ ) (Table 4). Members of the Mesotoga genus are able to oxidize sugars, although with low efficiency, only when $\mathrm{S}^{0}$ is used as the terminal electron acceptor $[26,27,66,148,149]$. This process gives acetic acid, $\mathrm{CO}_{2}$, and sulfide $(2 \mathrm{~mol}$ of acetate and $4 \mathrm{~mol}$ of sulfide per mol of glucose), with no or trace amounts $\mathrm{of}_{2}$ (Table 4) [27]. After 250 days of Ms. prima cultivation, $9.21 \pm 0.13 \mathrm{mmol} / \mathrm{L}$ of acetate was measured in the presence of $S^{0}$ rather than $1.67 \pm 0.21 \mathrm{mM}$ obtained in its absence (Table 4) [27]. Fadhlaoui and collaborators [27] argued that the metabolic differences between Thermotoga spp. and Ms. prima strains are related to the absence of a bifurcating [FeFe]hydrogenase and the accumulation of NADH in Ms. prima, leading to growth inhibition in the absence of an external electron acceptor [27]. However, Ms. prima and Ms. infera strains grew more efficiently in a syntrophic association with a hydrogenotrophic microbial partner that serves as a biological electron acceptor compared to growing Mesotoga in a pure culture with sulfur as electron acceptor [26,27]. Boileau et al. [107] investigated the different responses of fermentation performance to different S-sources (Table 4) [107]. Among these compounds (Table 4), thiosulfate, cysteine, and $\mathrm{Na}_{2} \mathrm{~S}$ were the most efficient ones to optimize T. maritima glucose fermentation (Table 4) [107]. Biogas production and glucose utilization increased in the order of no S-source $<$ DMSO $<\mathrm{S}^{0}<$ Thio $<$ Methionine (Met) $<\mathrm{Na}_{2} \mathrm{~S}<$ Cysteine (Cys) (Table 4) [107]. Moreover, $\mathrm{Na}_{2} \mathrm{~S}$ and Cys increased acetic acid production 3-fold and $\mathrm{H}_{2}$ production 2-fold (Table 4). Thiosulfate seemed to promote lactic acid formation $(0.8 \pm 0.1 \mathrm{mM} \mathrm{w} / \mathrm{o}$ S-source and $6.3 \pm 0.6 \mathrm{mM}$ with Thio) without affecting other products [107]. Surprisingly, lactic acid was dependent on thiosulfate concentration ( $0.3 \mathrm{~mol} / \mathrm{mol}$ glucose $\mathrm{w} / \mathrm{o}$ Thio and $0.6 \mathrm{~mol} / \mathrm{mol}$ glucose with $0.24 \mathrm{mmol}$ Thio), even though the proportion between lactic and acetic acid yields remained constant (Table 4). DMSO had no significant impact on T. maritima fermentation parameters (Table 4) [107].

In the presence of thiosulfate, the growth and glutamate production of Fervidobacterium is stimulated; however, $\mathrm{S}^{0}$ does not seem to help overcoming the $\mathrm{H}_{2}$-feedback inhibition (Table 4) $[32,80,88,144]$. P. olearia, P. sibirica, and Ts. Africanus produced small amounts of ethanol ( $0.17 \mathrm{mM}$ for both Petrotoga species and $0.79 \mathrm{mM}$ for Ts. africanus) only in the absence of S-sources (Table 4) [93,145]. Pseudot. lettingae produced L-alanine, at the expense of acetic acid, only when thiosulfate or $S^{0}$ was present in the medium using methanol as the substrate (Table 4) [75]. Meanwhile, the presence of thiosulfate or $\mathrm{S}^{0}$ resulted in increased production of acetic acid and decreased production of alanine in Pseudot. hypogea, Ts. melaniensis, Ts. geolei, P. olearia, and P. sibirica cultures, using glucose or xylose as the carbon source (Table 4) $[77,87,90,93]$. When $S^{0}$ is available, no hydrogen could be detected in $M n$. hydrogenitolerans growing on glucose [101].

Thermotogae members have been widely employed to degrade different organic wastes, and their degradation significantly benefited from the presence of a reducing agent $[51-54,113,116,138]$. It is noteworthy to mention that high concentrations of thiosulfinate, a volatile organo-sulfur compound found in organic wastes, has an inhibitory effect on $T$. maritima growth [54]. Similarly, Tao et al. [150] demonstrated that thiosulfinate inhibited the $\mathrm{H}_{2}$ production by mesophilic seed sludge when co-fermenting food wastes [150]. 


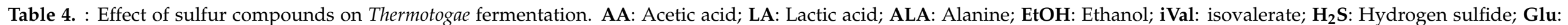

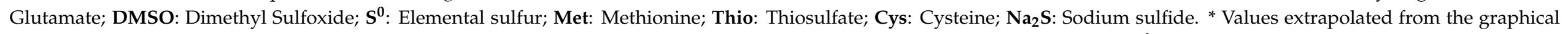
representation of data. ${ }^{* *}$ Concentrations of Sulfur compounds are 0.03 mol equivalent of sulfur. ${ }^{a} \mathrm{H}_{2}$ produced millimolar equivalent; ${ }^{\mathrm{b}}$ mmol; ${ }^{\mathrm{c}} \mu \mathrm{M}$.

\begin{tabular}{|c|c|c|c|c|c|c|c|c|c|c|c|c|}
\hline \multirow{2}{*}{ Organism } & \multirow{2}{*}{$\begin{array}{c}\text { Carbon Source } \\
(\mathrm{mM})\end{array}$} & \multirow{2}{*}{$\begin{array}{c}\text { Sulfur } \\
\text { Source } \\
(\mathrm{mM})\end{array}$} & \multirow{2}{*}{$\begin{array}{c}\text { Substrate } \\
\text { Consumed } \\
(\mathrm{mmol} / \mathrm{L})\end{array}$} & \multicolumn{8}{|c|}{ Products mmol/L Culture } & \multirow{2}{*}{ Ref. } \\
\hline & & & & $\mathrm{H}_{2}$ & AA & LA & ALA & EtOH & iVal & $\mathrm{H}_{2} \mathrm{~S}$ & Glu & \\
\hline \multirow{15}{*}{$\begin{array}{c}T . \\
\text { maritima }\end{array}$} & \multirow{6}{*}{ Glucose (25) } & $\mathrm{w} / \mathrm{o}$ & $7.1 \pm 0.4$ & $21.3 \pm 2.1$ & $10.1 \pm 0.8$ & $0.8 \pm 0.1$ & - & & & & & \multirow{13}{*}[107]{} \\
\hline & & $\mathrm{S}^{0 * *}$ & $16.6 \pm 0.8$ & $46.1 \pm 4.6$ & $23.8 \pm 1.9$ & $3.4 \pm 0.3$ & - & & & & & \\
\hline & & Met** & $18.3 \pm 0.9$ & $53.3 \pm 5.3$ & $26.5 \pm 2.1$ & $3.1 \pm 0.3$ & - & & & & & \\
\hline & & Thio ** & $17.5 \pm 0.9$ & $47.3 \pm 4.7$ & $24.1 \pm 1.9$ & $6.3 \pm 0.6$ & - & & & & & \\
\hline & & Cys ** & $20.4 \pm 1.0$ & $58.5 \pm 5.8$ & $30.5 \pm 2.4$ & $4.1 \pm 0.4$ & - & & & & & \\
\hline & & $\mathrm{Na}_{2} \mathrm{~S} * *$ & $20.4 \pm 1.0$ & $54.9 \pm 5.5$ & $30.7 \pm 2.5$ & $4.7 \pm 0.5$ & - & & & & & \\
\hline & \multirow{7}{*}{ Glucose (60) } & w/o Thio & $17.7 \pm 1.9$ & $25.0 \pm 2.2$ & $12.8 \pm 1.0$ & $5.4 \pm 0.6$ & $1.39 \pm 0.2$ & & & & & \\
\hline & & Thio $(0.01)$ & $20.0 \pm 1.1$ & $31.0 \pm 2.3$ & $16.0 \pm 0.8$ & $10.2 \pm 1.1$ & - & & & & & \\
\hline & & Thio (0.03) & $28.0 \pm 1.5$ & $57.9 \pm 4.8$ & $30.6 \pm 1.9$ & $8.2 \pm 0.7$ & - & & & & & \\
\hline & & Thio (0.06) & $38.5 \pm 2.0$ & $73.3 \pm 5.9$ & $38.2 \pm 2.4$ & $18.1 \pm 1.8$ & - & & & & & \\
\hline & & Thio (0.12) & $45.7 \pm 2.5$ & $99.7 \pm 8.3$ & $52.4 \pm 3.3$ & $15.4 \pm 1.6$ & $3.8 \pm 0.3$ & & & & & \\
\hline & & Thio (0.18) & $45.4 \pm 2.2$ & $86.9 \pm 8.2$ & $45.0 \pm 2.2$ & $23.4 \pm 2.3$ & - & & & & & \\
\hline & & Thio $(0.24)$ & $43.8 \pm 2.2$ & $88.6 \pm 8.9$ & $46.1 \pm 3.3$ & $26.4 \pm 1.4$ & $3.8 \pm 0.2$ & & & & & \\
\hline & \multirow{2}{*}{ Glucose (20) } & $\mathrm{w} / \mathrm{o}$ & 13.70 & 36.09 & 15.62 & & 0.70 & & & n.d. & & \multirow{2}{*}[145]{} \\
\hline & & Thio (20) & 13.55 & 4.02 & 15.99 & & 0.80 & & & 14.45 & & \\
\hline \multirow{2}{*}{$\begin{array}{c}T . \\
\text { neapolitana }\end{array}$} & \multirow{2}{*}{ Glucose (20) } & $\mathrm{w} / \mathrm{o}$ & 14.00 & 31.67 & 18.27 & & 0.87 & & & n.d. & & \multirow{2}{*}[145]{} \\
\hline & & Thio (20) & 13.90 & 16.07 & 16.12 & & 0.60 & & & 7.39 & & \\
\hline \multirow{3}{*}{$\begin{array}{l}\text { Pseudot. } \\
\text { lettingae }\end{array}$} & \multirow{3}{*}{ Methanol (20) } & $\mathrm{w} / \mathrm{o}$ & 19.70 & n. d. & 13.70 & & - & & & - & & \multirow{3}{*}{ [75] } \\
\hline & & Thio (20) & 18.7 & n. d. & - & & 5.8 & & & 11.2 & & \\
\hline & & $S^{0}(2 \%)$ & 10.6 & n. d. & - & & 3.1 & & & 7.3 & & \\
\hline \multirow{2}{*}{$\begin{array}{l}\text { Pseudot. } \\
\text { hypogea }\end{array}$} & \multirow{2}{*}{ Glucose (20) } & $\mathrm{w} / \mathrm{o}$ & 8.60 & 29.03 & 4.49 & & 1.71 & & & n. d. & & \multirow{2}{*}{ [145] } \\
\hline & & Thio (20) & 14.39 & 2.29 & 19.7 & & 1.06 & & & 15.08 & & \\
\hline
\end{tabular}


Table 4. Cont.

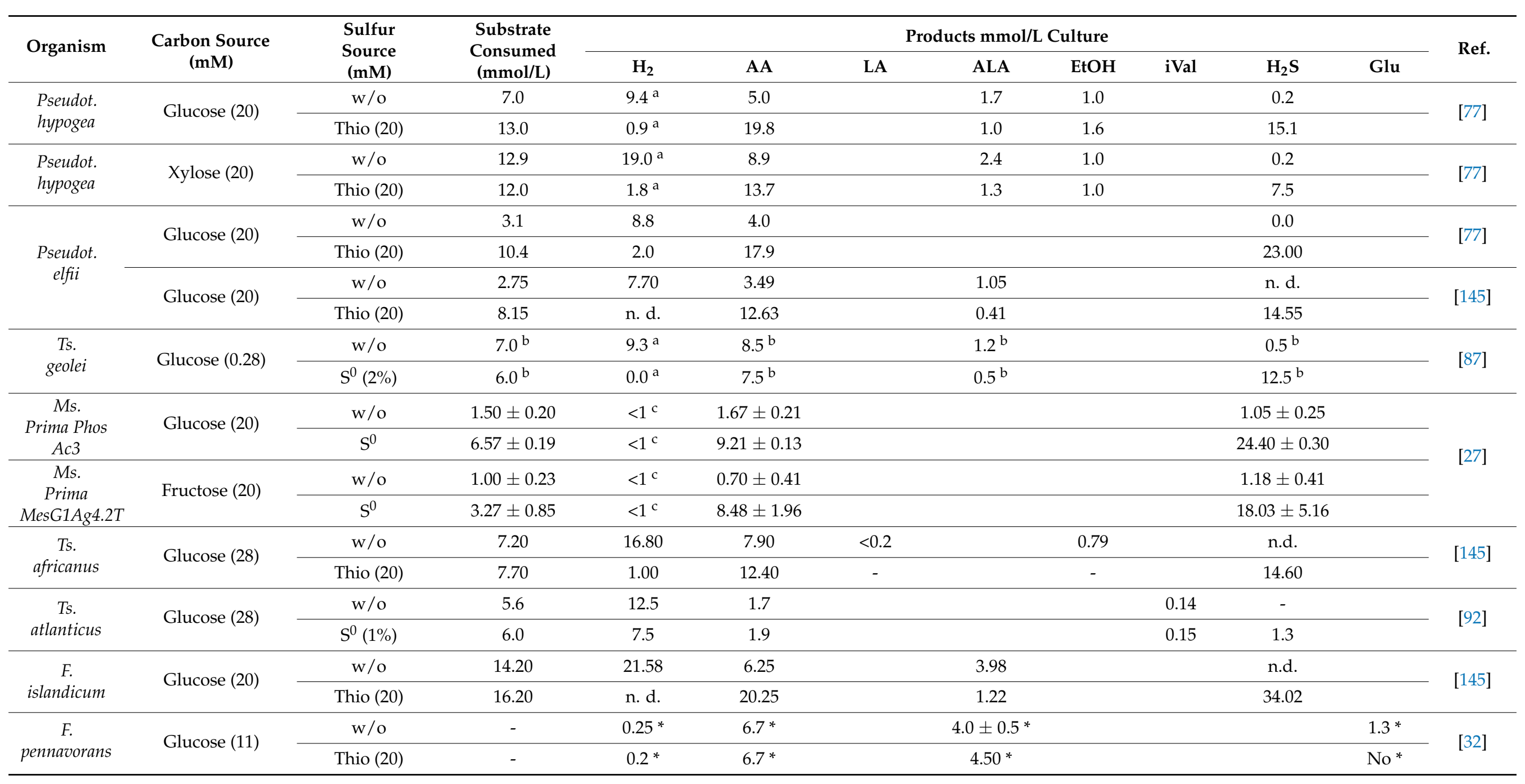




\section{Metal Ions}

Typically, hydrothermal ecosystems are enriched with essential micronutrients and trace metals such as soluble and insoluble iron, manganese, cobalt, and molybdenum. Some terrestrial hydrothermal waters are also characterized by chromium and uranium contents of several micrograms per liter [151]. The physiological roles that most of these metals play in microbial metabolism are still largely unknown. It is believed that their functions include energy generation and biosynthesis [151]. In addition, $\mathrm{Mn}, \mathrm{Fe}, \mathrm{Zn}$, and Co metals are vitally important micro-elements for growth, essential for cellular transport processes, and serve as cofactors for many enzymes [152]. Understanding the physicochemical properties of extreme habitats can help to determine the metal toxicity limits on microbial growth in laboratory settings. Indeed, metal susceptibility tests have been carried out on T. neapolitana, T. maritima, and Ts. africanus, and have identified the following toxicity order: cadmium $(1.0-10.0 \mu \mathrm{M})>$ zinc $(0.01-0.1 \mathrm{mM})>\operatorname{nickel}(1.0-5.0 \mathrm{mM})>$ cobalt $(1.0-10.0 \mathrm{mM})$ [153].

Attention has also been paid to Fe (III) reduction by thermophilic bacteria, since Fe (III) may work as an external electron acceptor in microbial metabolism [154]. Members of the phylum Thermotogae are capable of coupling the reduction of iron with the oxidation of a wide range of organic and inorganic compounds. T. maritima reduced Fe (III) into Fe (II) exclusively with molecular hydrogen as an electron donor [154]. Fe (III) reduction has also been reported to stimulate growth and mitigate $\mathrm{H}_{2}$ inhibition in Pseudot. lettingae, Pseudot. subterranea, Pseudot. elfii, Ts. affectus, Ts. globiformans, and Ts. activus [75,76,88,89,91]. The recently characterized member of the order Mesoaciditogales, A. saccharophila, changed fermentation end-products when growing with Fe (III), favoring the production of small amounts of acetate, isobutyrate, and isovalerate [14].

Ions and metals are generally supplied in Thermotogae growth media through Balch's oligo-elements solution [155]. The removal of oligo-elements from T. maritima cultures resulted in a minor increase in lactic acid production (1.2 vs. $4.3 \mathrm{mmol} / \mathrm{L})$ and a decrease in $\mathrm{H}_{2}$ productivity (12.4 vs. $8.8 \mathrm{mmol} / \mathrm{h} / \mathrm{L}$ ) [52]. Limitation in iron lowered $\mathrm{H}_{2}$ production by deviating the fermentation pathway towards the production of more reduced endproducts such as lactic acid in mixed cultures [156,157]. Another study [139] highlighted how the supplementation of Fe ions to mixed cultures had pronounced effect on hydrogen activity [139]. Similarly, $\mathrm{Fe}^{2+}$ (as well as $\mathrm{Co}, \mathrm{Ni}$ and $\mathrm{Mn}$ ) stimulated Pseudot. hypogea alcohol dehydrogenase activity $(\mathrm{ADH})$, an iron-containing enzyme involved in alcohol fermentation, by $10-15 \%$, while $\mathrm{Zn}^{2+}$ completely inhibited the enzyme activity [158]. On the same base, the inclusion of tungsten in the growth medium of T. maritima increased the specific activity of both hydrogenase (by up to 10-fold) and PFOR in cell-free extracts, although the function of tungsten in the metabolism of T. maritima is not clear $[123,126]$.

As for magnesium, potassium, and calcium ions, they not only play critical roles in bacterial growth, but also act as enzyme cofactors and ensure the survival of microorganisms in their hot ecosystems, by protecting double-stranded DNA from degradation [159]. The best cell yields were obtained with a low concentration of $\mathrm{Mg}^{2+}$ and a high concentration of $\mathrm{Ca}^{2+}$ [126]. It would be worthwhile to dig further into the metal ions repercussions on Thermotogae metabolism in future research.

\section{Conclusions}

Steam reforming of methane $\left(\mathrm{CH}_{4}\right)$ is currently used to produce hydrogen in the industry, as it is the most economic technology available so far. Producing hydrogen by biological means at an industrial scale remains as a challenge. Within the race to find the best way to generate hydrogen via microbes (e.g., choice of strains, substrates, fermentation conditions), Thermotogae seem to have many unique advantages. Optimization of their cultivation conditions is fundamental to improve the overall productivity of the fermentation system and its profitability, which determine the feasibility of replacing the current methods of hydrogen production.

The phylum Thermotogae comprises a wide collection of species with astonishing and unique features associated to their original habitats. Extensive research has shown tremen- 
dous potentials of using these bacteria in biological production of hydrogen, degradation of wastes, and isolation of thermostable enzymes.

Many factors affect the anaerobic metabolism of Thermotogae species, including operating conditions (shaking, inoculum, gas sparging, and culture/headspace volume ratio), temperature, $\mathrm{pH}$, nitrogen, sulfur-containing compounds, sodium chloride, phosphate, and metal ions. Optimization of these fermentation parameters has been intensively pursued with Thermotoga and Pseudothermotoga species, which are the best hydrogen producers in the phylum. In contrast, little is known regarding other species of the phylum, especially their ability to synthesize desirable biological products.

In general, Thermotogae fermentation is affected by the accumulation of produced biogas and organic acids because they increase hydrogen partial pressure inside of the bioreactor and drastically reduce the $\mathrm{pH}$ of the cultivation medium. Consequently, the metabolic process stops before the substrate is completely consumed. Gas sparging, stirring, and adjusting culture/headspace volume ratio can help to overcome the inhibition on growth caused by hydrogen accumulation. Implementing these strategies and adjusting $\mathrm{pH}$ during the fermentation process can result in high hydrogen yields and efficient consumption of substrates. A reduction of fermentation time by starting with the right inoculum size could cast favorable great perspectives on the economics of the industrial processes.

This review highlights the importance of nitrogen-containing compounds that need to be supplied to the medium to stimulate bacterial growth. Overall, yeast extract and tryptone are the preferred forms of nitrogen. Sulfur-containing compounds not only play a critical role in bacterial growth but also divert reducing power to selectively produce certain end-products in Thermotogae metabolism.

Until now, the impact of metal ions and salts on the fermentation process has not been well investigated even though it has been demonstrated that they could stimulate many key enzymes involved in various metabolic pathways.

In summary, the extensive data collection of this review offers a great reference for the optimization and development of sustainable bioprocesses based on Thermotogae species and helps to generate insightful perspectives for the exploitation of these anaerobic bacteria in biotechnological processes.

Funding: This research was funded by BioRECO 2 VER Project, through the European Union's Horizon 2020 Research and Innovation Programme under Grant Agreement No. 760431.

Acknowledgments: The authors would like to thank Lucio Caso (CNR-ICB) for the technical support in preparing the manuscript.

Conflicts of Interest: The authors declare no conflict of interest. The funding agencies gave their permissions to the publication of manuscript.

\section{References}

1. Huber, R.H.M. Thermotogales; Dworkin, M., Falkow, S., Rosenberg, E., Schleifer, K.H., Stackebrandt, E., Eds.; Springer: New York, NY, USA, 2006; pp. 899-922.

2. Bhandari, V.; Gupta, R.S. The Phylum Thermotogae. In The Prokaryotes; Rosenberg, E., DeLong, E.F., Lory, S., Stackebrandt, E., Thompson, F., Eds.; Springer: Berlin/Heidelberg, Germany, 2014.

3. Huber, R.; Langworthy, T.A.; König, H.; Thomm, M.; Woese, C.R.; Sleytr, U.B.; Stetter, K.O. Thermotoga maritima Sp. Nov. Represents a New Genus of Unique Extremely Thermophilic Eubacteria Growing up to $90^{\circ} \mathrm{C}$. Arch. Microbiol. 1986, 144, 324-333. [CrossRef]

4. Belahbib, H.; Summers, Z.M.; Fardeau, M.; Joseph, M.; Tamburini, C.; Dolla, A.; Ollivier, B.; Armougom, F. Towards a Congruent Reclassification and Nomenclature of the Thermophilic Species of the Genus Pseudothermotoga within the Order Thermotogales. Syst. Appl. Microbiol. 2018, 41, 555-563. [CrossRef] [PubMed]

5. Patel, B.K.C.; Morgan, H.W.; Daniel, R.M. Fervidobacterium nodosum Gen. Nov. and Spec. Nov., a New Chemoorganotrophic, Caldoactive, Anaerobic Bacterium. Arch. Microbiol. 1985, 141, 63-69. [CrossRef]

6. Windberger, E.; Huber, R.; Trincone, A.; Fricke, H.; Stetter, K.O. Thermotoga thermarum Sp. Nov. and Thermotoga Neapolitana Occurring in African Continental Solfataric Springs. Arch. Microbiol. 1989, 151, 506-512. [CrossRef] 
7. DiPippo, J.L.; Nesbø, C.L.; Dahle, H.; Doolittle, W.F.; Birkland, N.K.; Noll, K.M. Kosmotoga olearia Gen. Nov., Sp. Nov., a Thermophilic, Anaerobic Heterotroph Isolated from an Oil Production Fluid. Int. J. Syst. Evol. Microbiol. 2009, 59, $2991-3000$. [CrossRef] [PubMed]

8. Nesbø, C.L.; Bradnan, D.M.; Adebusuyi, A.; Dlutek, M.; Petrus, A.K.; Foght, J.; Doolittle, W.F.; Noll, K.M. Mesotoga prima Gen. Nov., Sp. Nov., the First Described Mesophilic Species of the Thermotogales. Extremophile 2012, 16, 387-393. [CrossRef]

9. Ben Hania, W.; Godbane, R.; Postec, A.; Hamdi, M.; Ollivier, B.; Fardeau, M.L. Defluviitoga tunisiensis Gen. Nov., Sp. Nov., a Thermophilic Bacterium Isolated from a Mesothermic and Anaerobic Whey Digester. Int. J. Syst. Evol. Microbiol. 2012, 62, $1377-1382$. [CrossRef]

10. Davey, M.E.; Wood, W.A.; Key, R.; Nakamura, K.; Stahl, D.A. Isolation of Three Species of Geotoga and Petrotoga: Two New Genera, Representing a New Lineage in the Bacterial Line of Descent Distantly Related to the "Thermotogales". Syst. Appl. Microbiol. 1993, 16, 191-200. [CrossRef]

11. Wery, N.; Lesongeur, F.; Pignet, P.; Derennes, V.; Cambon-Bonavita, M.A.; Godfroy, A.; Barbier, G. Marinitoga camini Gen. Nov., Sp. Nov., a Rod-Shaped Bacterium Belonging to the Order Thermotogales, Isolated from a Deep-Sea Hydrothermal Vent. Int. J. Syst. Evol. Microbiol. 2001, 51, 495-504. [CrossRef]

12. Jayasinghearachchi, H.S.; Lal, B. Oceanotoga Teriensis Gen. Nov., Sp. Nov., a Thermophilic Bacterium Isolated from Offshore Oil-Producing Wells. Int. J. Syst. Evol. Microbiol. 2011, 61, 554-560. [CrossRef]

13. Reysenbach, A.L.; Liu, Y.; Lindgren, A.R.; Wagner, I.D.; Sislak, C.D.; Mets, A.; Schouten, S. Mesoaciditoga lauensis Gen. Nov., Sp. Nov., a Moderately Thermoacidophilic Member of the Order Thermotogales from a Deep-Sea Hydrothermal Vent. Int. J. Syst. Evol. Microbiol. 2013, 63, 4724-4729. [CrossRef] [PubMed]

14. Itoh, T.; Onishi, M.; Kato, S.; Iino, T.; Sakamoto, M.; Kudo, T.; Takashina, T.; Ohkuma, M. Athalassotoga saccharophila Gen. Nov., Sp. Nov., Isolated from an Acidic Terrestrial Hot Spring, and Proposal of Mesoaciditogales Ord. Nov. and Mesoaciditogaceae Fam. Nov. in the Phylum Thermotogae. Int. J. Syst. Evol. Microbiol. 2016, 66, 1045-1051. [CrossRef] [PubMed]

15. Feng, Y.; Cheng, L.; Zhang, X.; Li, X.; Deng, Y.; Zhang, H. Thermococcoides shengliensis Gen. Nov., Sp. Nov., a New Member of the Order Thermotogales Isolated from Oil-Production Fluid. Int. J. Syst. Evol. Microbiol. 2010, 60, 932-937. [CrossRef] [PubMed]

16. Nelson, K.; Clayton, R.; Gill, S.; Gwinn, M.; Dodson, R.; Haft, D.; Hickey, E.; Peterson, J.; Nelson, W.; Ketchum, K.; et al. Evidence for Lateral Gene Transfer between Archae and Bacteria from Genome Sequence of Thermotoga maritima. Nature 1999, 399, 323-329. [CrossRef] [PubMed]

17. Conners, S.B.; Mongodin, E.F.; Johnson, M.R.; Montero, C.I.; Nelson, K.E.; Kelly, R.M. Microbial Biochemistry, Physiology, and Biotechnology of Hyperthermophilic Thermotoga Species. FEMS Microbiol. Rev. 2006, 30, 872-905. [CrossRef]

18. Rodionov, D.A.; Rodionova, I.A.; Li, X.; Ravcheev, I.; Tarasova, Y.; Portnoy, V.A.; Zengler, K.; Osterman, A.L. Transcriptional Regulation of the Carbohydrate Utilization Network in Thermotoga maritima. Front. Microbiol. 2013, 4, 244. [CrossRef]

19. Galperin, M.Y.; Noll, K.M.; Romano, A.H. The Glucose Transport System of the Hyperthermophilic Anaerobic Bacterium Thermotoga neapolitana. Appl. Environ. Microbiol. 1996, 62, 2915-2918. [CrossRef] [PubMed]

20. Paulsen, I.T.; Nguyen, L.; Sliwinski, M.K.; Rabus, R.; Jr, M.H.S. Microbial Genome Analyses: Comparative Transport Capabilities in Eighteen Prokaryotes. J. Mol. Biol. 2000, 301, 75-100. [CrossRef]

21. Nanavati, D.; Thirangoon, K.; Noll, K.M. Several Archaeal Homologs of Putative Oligopeptide-Binding Proteins Encoded by Thermotoga maritima Bind Sugars. Appl. Environ. Microbiol. 2006, 72, 1336-1345. [CrossRef]

22. Latif, H.; Sahin, M.; Tarasova, J.; Tarasova, Y.; Portnoy, V.A.; Nogales, J.; Zengler, K. Adaptive Evolution of Thermotoga maritima Reveals Plasticity of the ABC Transporter Network. Appl. Environ. Microbiol. 2015, 81, 5477-5485. [CrossRef]

23. Boucher, N.; Noll, K.M. Substrate Adaptabilities of Thermotogae Mannan Binding Proteins as a Function of Their Evolutionary Histories. Extremophiles 2016, 20, 771-783. [CrossRef] [PubMed]

24. Thauer, R.K.; Jungermann, K.; Decker, K. Energy Conservation in Chemotrophic Anaerobic Bacteria. Bacteriol. Rev. 1977, 41, 100-180. [CrossRef] [PubMed]

25. Ben Hania, W.; Ghodbane, R.; Postec, A.; Brochier-Armanet, C.; Hamdi, M.; Fardeau, M.L.; Ollivier, B. Cultivation of the First Mesophilic Representative ("Mesotoga") within the Order Thermotogales. Syst. Appl. Microbiol. 2011, 34, 581-585. [CrossRef] [PubMed]

26. Hania, W.B.; Postec, A.; Aüllo, T.; Ranchou-Peyruse, A.; Erauso, G.; Brochier-Armanet, C.; Hamdi, M.; Ollivier, B.; Saint-Laurent, S.; Magot, M.; et al. Mesotoga infera Sp. Nov., a Mesophilic Member of the Order Thermotogales, Isolated from an Underground Gas Storage Aquifer. Int. J. Syst. Evol. Microbiol. 2013, 63, 3003-3008. [CrossRef] [PubMed]

27. Fadhlaoui, K.; Hania, W.B.; Armougom, F.; Bartoli, M.; Fardeau, M.L.; Erauso, G.; Brasseur, G.; Aubert, C.; Hamdi, M.; BrochierArmanet, C.; et al. Obligate Sugar Oxidation in Mesotoga Spp., Phylum Thermotogae, in the Presence of Either Elemental Sulfur or Hydrogenotrophic Sulfate-Reducers as Electron Acceptor. Environ. Microbiol. 2017, 20, 281-292. [CrossRef] [PubMed]

28. Janssen, P.H.; Morgan, H.W. Heterotrophic Sulfur Reduction by Thermotoga Sp. Strain FjSS3.B1. FEMS Microbiol. Lett. 1992, 96, 213-218. [CrossRef] [PubMed]

29. Schröder, C.; Selig, M.; Schönheit, P. Glucose Fermentation to Acetate, $\mathrm{CO}_{2}$ and $\mathrm{H}_{2}$ in the Anaerobic Hyperthermophilic Eubacterium Thermotoga maritima: Involvement of the Embden-Meyerhof Pathway. Arch. Microbiol. 1994, 161, 460-470. [CrossRef]

30. D'Ippolito, G.; Dipasquale, L.; Vella, F.M.; Romano, I.; Gambacorta, A.; Cutignano, A.; Fontana, A. Hydrogen Metabolism in the Extreme Thermophile Thermotoga neapolitana. Int. J. Hydrogen Energy 2010, 35, 2290-2295. [CrossRef] 
31. Dipasquale, L.; d'Ippolito, G.; Fontana, A. Capnophilic Lactic Fermentation and Hydrogen Synthesis by Thermotoga neapolitana: An Unexpected Deviation from the Dark Fermentation Model. Int. J. Hydrogen Energy 2014, 39, 4857-4862. [CrossRef]

32. Wushke, S.; Fristensky, B.; Zhang, X.L.; Spicer, V.; Krokhin, O.V.; Levin, D.B.; Stott, M.B.; Sparling, R. A Metabolic and Genomic Assessment of Sugar Fermentation Profiles of the Thermophilic Thermotogales, Fervidobacterium pennivorans. Extremophiles 2018, 22, 965-974. [CrossRef]

33. Vijayakumar, J.; Aravindan, R.; Viruthagiri, T. Lactic Acid and Its Potential Applications in Industries. Bioprod. Biosyst. Eng. 2007, 42, 101-103.

34. Roehr, M.; Kosaric, N.; Vardar-Sukan, F.; Pieper, H.J.; Senn, T. The Biotechnology of Ethanol. Classical and Future Applications; Wiley: Hoboken, NJ, USA, 2005; p. 245. ISBN 978-3-527-60234-6.

35. Vieille, C.; Zeikus, G.J. Hyperthermophilic Enzymes: Sources, Uses, and Molecular Mechanisms for Thermostability. Microbiol. Mol. Biol. Rev. 2001, 65, 1-43. [CrossRef] [PubMed]

36. Ul Haq, I.; Hussain, Z.; Khan, M.; Muneer, B.; Afzal, S.; Majeed, S.; Akram, F. Kinetic and Thermodynamic Study of Cloned Thermostable Endo-1, 4- b -Xylanase from Thermotoga petrophila in Mesophilic Host. Mol. Biol. Rep. 2012, 39, 7251-7261. [CrossRef] [PubMed]

37. Ul Haq, I.; Tahir, S.F.; Aftab, M.N.; Akram, F.; ur Rehman, A.; Nawaz, A.; Mukhtar, H. Purification and Characterization of a Thermostable Cellobiohydrolase from Thermotoga petrophila. Protein Pept. Lett. 2018, 25, 1003-1014. [CrossRef] [PubMed]

38. Colussi, F.; Viviam, M.; Ian, S.; Junio, M. Oligomeric State and Structural Stability of Two Hyperthermophilic $\beta$-Glucosidases from Thermotoga petrophila. Amino Acids 2015, 47, 937-948. [CrossRef] [PubMed]

39. Pollo, S.M.J.; Zhaxybayeva, O.; Nesbø, C.L. Insights into Thermoadaptation and the Evolution of Mesophily from the Bacterial Phylum Thermotogae. Can. J. Microbiol. 2015, 61, 655-670. [CrossRef] [PubMed]

40. Fatima, B.; Aftab, M.; Ul Haq, I. Cloning, Purifiication, and Characterization of Xylose Isomerase from Thermotoga naphthophila RKU-10. J. Basic Microbiol. 2016, 56, 949-962. [CrossRef]

41. Lopes, J.L.S.; Yoneda, J.S.; Martins, J.M.; Demarco, R. Environmental Factors Modulating the Stability and Enzymatic Activity of the Petrotoga mobilis Esterase (PmEst). PLoS ONE 2016, 11, e0158146. [CrossRef]

42. Intagun, W.; Kanoksilapatham, W. A Review: Biodegradation and Applications of Keratin Degrading Microorganisms and Keratinolytic Enzymes, Focusing on Thermophiles and Thermostable Serine Proteases. Am. J. Appl. Sci. Rev. 2017, 14, 1016-1023. [CrossRef]

43. Hamid, A.; Aftab, M.N. Cloning, Purification, and Characterization of Recombinant Thermostable $\beta$-Xylanase Tnap_0700 from Thermotoga naphthophila. Appl. Biochem. Biotechnol. 2019, 189, 1274-1290. [CrossRef]

44. Kang, E.; Jin, H.; La, J.W.; Park, S.; Kim, W.; Lee, W. Identification of Keratinases from Fervidobacterium islandicum AW-1 Using Dynamic Gene Expression pro Fi Ling. Microb. Biotechnol. 2019, 13, 442-457. [CrossRef] [PubMed]

45. European Commission. Communication from the Commission to the European Parliament, the Council, the European Economic and Social Committee and the Committee of the Regions; A Hydrogen Strategy for a Climate-Neutral Europe; 8.7.2020 COM 301 Final; European Commission: Brussels, Belgium, 2020.

46. Dipasquale, L.; d'Ippolito, G.; Gallo, C.; Vella, F.M.; Gambacorta, A.; Picariello, G.; Fontana, A. Hydrogen Production by the Thermophilic Eubacterium Thermotoga neapolitana from Storage Polysaccharides of the $\mathrm{CO}_{2}$-Fixing Diatom Thalassiosira weissflogii. Int. J. Hydrogen Energy 2012, 37, 12250-12257. [CrossRef]

47. Angenent, L.; Karim, K.; Al-Dahhan, M.; Wrenn, B.; Domiguez-Espinosa, R. Production of Bioenergy and Biochemicals from Industrial and Agricultural Wastewater. Trends Biotechnol. 2004, 22, 477-485. [CrossRef] [PubMed]

48. De Vrije, T.; de Haas, G.G.; Tan, G.B.; Keijsers, E.R.P.; Claassen, P.A.M. Pretreatment of Miscanthus for Hydrogen Production by Thermotoga elfii. Hydrog. Energy 2002, 27, 1381-1390. [CrossRef]

49. De Vrije, T.; Budde, M.A.W.; Lips, S.J.; Bakker, R.R.; Mars, A.E.; Claassen, P.A.M. Hydrogen Production from Carrot Pulp by the Extreme Thermophiles Caldicellulosiruptor saccharolyticus and Thermotoga neapolitana. Int. J. Hydrogen Energy 2010, 35, 13206-13213. [CrossRef]

50. Mars, A.E.; Veuskens, T.; Budde, M.A.W.; Van Doeveren, P.F.; Lips, S.J.; Bakker, R.R.; De Vrije, T.; Claassen, P.A.M. Biohydrogen Production from Untreated and Hydrolyzed Potato Steam Peels by the Extreme Thermophiles Caldicellulosiruptor saccharolyticus and Thermotoga neapolitana. Int. J. Hydrogen Energy 2010, 35, 7730-7737. [CrossRef]

51. Cappelletti, M.; Bucchi, G.; De Sousa Mendes, J.; Alberini, A.; Fedi, S.; Bertin, L.; Frascari, D. Biohydrogen Production from Glucose, Molasses and Cheese Whey by Suspended and Attached Cells of Four Hyperthermophilic Thermotoga Strains. J. Chem. Technol. Biotechnol. 2012, 87, 1291-1301. [CrossRef]

52. Saidi, R.; Liebgott, P.P.; Gannoun, H.; Ben Gaida, L.; Miladi, B.; Hamdi, M.; Bouallagui, H.; Auria, R. Biohydrogen Production from Hyperthermophilic Anaerobic Digestion of Fruit and Vegetable Wastes in Seawater: Simplification of the Culture Medium of Thermotoga maritima. Waste Manag. 2018, 71, 474-484. [CrossRef]

53. Saidi, R.; Liebgott, P.P.; Hamdi, M.; Auria, R.; Bouallagui, H. Enhancement of Fermentative Hydrogen Production by Thermotoga maritima through Hyperthermophilic Anaerobic Co-Digestion of Fruit-Vegetable and Fish Wastes. Int. J. Hydrogen Energy 2018, 43, 23168-23177. [CrossRef]

54. Saidi, R.; Hamdi, M.; Bouallagui, H. Hyperthermophilic Hydrogen Production in a Simplified Reaction Medium Containing Onion Wastes as a Source of Carbon and Sulfur. Environ. Sci. Pollut. Res. 2020, 27, 17382-17392. [CrossRef] 
55. Amend, J.P.; Shock, E.L. Energetics of Overall Metabolic Reactions of Thermophilic and Hyperthermophilic Archaea and Bacteria. FEMS Microbiol. Rev. 2001, 25, 175-243. [CrossRef] [PubMed]

56. Pradhan, N.; Dipasquale, L.; d'Ippolito, G.; Panico, A.; Lens, P.N.L.; Esposito, G.; Fontana, A. Hydrogen Production by the Thermophilic Bacterium Thermotoga neapolitana. Int. J. Mol. Sci. 2015, 16, 12578-12600. [CrossRef] [PubMed]

57. Levin, D.B.; Pitt, L.; Love, M. Biohydrogen Production: Prospects and Limitations to Practical Application. Int. J. Hydrogen Energy 2004, 29, 173-185. [CrossRef]

58. Schut, G.J.; Adams, M.W.W. The Iron-Hydrogenase of Thermotoga maritima Utilizes Ferredoxin and NADH Synergistically: A New Perspective on Anaerobic Hydrogen Production. J. Bacteriol. 2009, 191, 4451-4457. [CrossRef]

59. Yu, J.; Varga, M.; Mityas, C.; Noll, K.M. Liposome-Mediated DNA Uptake and Transient Expression in Thermotoga. Extremophiles 2001, 5, 53-60. [CrossRef]

60. Xu, H.; Han, D.; Xu, Z. Expression of Heterologous Cellulases in Thermotoga Sp. Strain RQ2. BioMed Res. Int. 2015, 2015 , 304523. [CrossRef]

61. Han, D.; Xu, Z. Development of a PyrE—Based Selective System for Thermotoga sp. Extremophiles 2017, 21, 297-306. [CrossRef]

62. Pradhan, N.; Dipasquale, L.; Panico, A.; Lens, P.N.L.; Esposito, G.; d'Ippolito, G.; Fontana, A. Hydrogen and Lactic Acid Synthesis by the Wild-Type and a Laboratory Strain of the Hyperthermophilic Bacterium Thermotoga neapolitana DSMZ 4359 under Capnophilic Lactic Fermentation Conditions. Int. J. Hydrogen Energy 2017, 42, 16023-16030. [CrossRef]

63. Grogan, D.W.; Carver, G.T.; Drake, J.W. Genetic fidelity under harsh conditions: Analysis of spontaneous mutation in the thermoacidophilic archaeon Sulfolobus acidocaldarius. Proc. Natl. Acad. Sci. USA 2001, 98, 7928-7933. [CrossRef]

64. Nguyen, T.A.D.; Pyo Kim, J.; Sun Kim, M.; Kwan Oh, Y.; Sim, S.J. Optimization of Hydrogen Production by Hyperthermophilic Eubacteria, Thermotoga maritima and Thermotoga neapolitana in Batch Fermentation. Int. J. Hydrogen Energy 2008, 33, $1483-1488$. [CrossRef]

65. Munro, S.A.; Zinder, S.H.; Walker, L.P. The Fermentation Stoichiometry of Thermotoga neapolitana and Influence of Temperature, Oxygen, and PH on Hydrogen Production. Biotechnol. Prog. 2009, 25, 1035-1042. [CrossRef] [PubMed]

66. Cappelletti, M.; Zannoni, D.; Postec, A.; Ollivier, B. Members of the Order Thermotogales: From Microbiology to Hydrogen Production. In Microbial BioEnergy: Hydrogen Production, Advances in Photosynthesis and Respiration; Springer: Dordrecht, The Netherlands, 2014; Volume 38, pp. 197-224.

67. Pradhan, N.; d'Ippolito, G.; Dipasquale, L.; Esposito, G.; Panico, A.; Lens, P.N.L.; Fontana, A. Simultaneous Synthesis of Lactic Acid and Hydrogen from Sugars via Capnophilic Lactic Fermentation by Thermotoga neapolitana Cf Capnolactica. Biomass Bioenergy 2019, 125, 17-22. [CrossRef]

68. Dreschke, G.; d'Ippolito, G.; Panico, A.; Lens, P.N.L.; Esposito, G.; Fontana, A. Enhancement of Hydrogen Production Rate by High Biomass Concentrations of Thermotoga Neapolitana. Int. J. Hydrogen Energy 2018, 43, 13072-13080. [CrossRef]

69. Dreschke, G.; Papirio, S.; Panico, A.; Lens, P.N.L.; Esposito, G.; d’Ippolito, G.; Fontana, A. H2-Rich Biogas Recirculation Prevents Hydrogen Supersaturation and Enhances Hydrogen Production by Thermotoga neapolitana Cf. Capnolactica. Int. J. Hydrogen Energy 2019, 44, 19698-19708. [CrossRef]

70. Dipasquale, L.; Pradhan, N.; d'Ippolito, G.; Fontana, A. Potential of Hydrogen Fermentative Pathways in Marine Thermophilic Bacteria: Dark Fermentation and Capnophilic Lactic Fermentation in Thermotoga and Pseudothermotoga Species. In Grand Challenges in Marine Biotechnology; Springer: Dordrecht, The Netherlands, 2018; pp. 217-235.

71. Nuzzo, G.; Landi, S.; Esercizio, N.; Manzo, E.; Fontana, A.; d'Ippolito, G. Capnophilic Lactic Fermentation from Thermotoga neapolitana: A Resourceful Pathway to Obtain Almost Enantiopure L-Lactic Acid. Fermentation 2019, 5, 34. [CrossRef]

72. Takahata, Y.; Nishijima, M.; Hoaki, T.; Maruyama, T. Thermotoga petrophila sp. Nov. and Thermotoga naphthophila Sp. Nov., Two Hyperthermophilic Bacteria from the Kubiki Oil Reservoir in Niigata, Japan. Int. J. Syst. Evol. Microbiol. 2001, 51, 1901-1909. [CrossRef] [PubMed]

73. Mori, K.; Yamazoe, A.; Hosoyama, A.; Ohji, S.; Fujita, N.; Ishibashi, J.I.; Kimura, H.; Suzuki, K.I. Thermotoga profunda Sp. Nov. and Thermotoga caldifontis Sp. Nov., Anaerobic Thermophilic Bacteria Isolated from Terrestrial Hot Springs. Int. J. Syst. Evol. Microbiol. 2014, 64, 2128-2136. [CrossRef] [PubMed]

74. Jannasch, H.W.; Huber, R.; Belkin, S.; Stetter, K.O. Thermotoga neapolitana Sp. Nov. of the Extremely Thermophilic, Eubacterial Genus Thermotoga. Arch. Microbiol. 1988, 150, 103-104. [CrossRef]

75. Balk, M.; Weijma, J.; Stams, A.J.M. Thermotoga Lettingae Sp. Nov., a Novel Thermophilic, Methanol-Degrading Bacterium Isolated from a Thermophilic Anaerobic Reactor. Int. J. Syst. Evol. Microbiol. 2002, 52, 1361-1368. [CrossRef] [PubMed]

76. Ravot, G.; Magot, M.; Fardeau, M.L.; Patel, B.K.C.; Prensier, G.; Egan, A.; Garcia, J.L.; Ollivier, B. Thermotoga elfii Sp. Nov., a Novel Thermophilic Bacterium from an African Oil-Producing Well. Int. J. Syst. Bacteriol. 1995, 45, 308-314. [CrossRef]

77. Fardeau, M.L.; Ollivier, B.C.; Patel, B.K.; Magot, M.; Thomas, P.; Rimbault, A.; Rocchiccioli, F.; Garcia, J.L. Thermotoga hypogea Sp. Nov., a Xylanolytic, Thermophilic Bacterium from an Oil-Producing Well. Int. J. Syst. Bacteriol. 1997, 147, 51-56. [CrossRef] [PubMed]

78. Jeanthon, C.; Reysenbach, A.L.; L'Haridon, S.; Gambacorta, A.; Pace, N.R.; Glénat, P.; Prieur, D. Thermotoga subterranea Sp. Nov., a New Thermophilic Bacterium Isolated from a Continental Oil Reservoir. Arch. Microbiol. 1995, 164, 91-97. [CrossRef] [PubMed]

79. Friedricht, A.B.; Antranikian, G. Keratin Degradation by Fervidobacterium pennavorans, a Novel Thermophilic Anaerobic Species of the Order Thermotogales. Appl. Environ. Microbiol. 1996, 62, 2875-2882. [CrossRef] [PubMed] 
80. Huber, R.; Woese, C.R.; Langworthy, T.A.; Kristjansson, J.K.; Stetter, K.O. Fervidobacterium islandicum Sp. Nov., a New Extremely Thermophilic Eubacterium Belonging to the "Thermotogales". Arch. Microbiol. 1990, 154, 105-111. [CrossRef]

81. Podosokorskaya, O.A.; Merkel, Y.A.; Kolganova, T.V.; Chernyh, N.A.; Miroshnichenko, M.L.; Bonch-Osmolovskaya, E.A.; Kublanov, I.V. Fervidobacterium riparium Sp. Nov., a Thermophilic Anaerobic Cellulolytic Bacterium Isolated from a Hot Spring. Int. J. Syst. Evol. Microbiol. 2011, 61, 2697-2701. [CrossRef]

82. Andrews, K.T.; Patel, B.K.C. Fervidobacterium gondwanense Sp. Nov., a New Thermophilic Anaerobic Bacterium Isolated from Nonvolcanically Heated Geothermal Waters of the Great Artesian Basin of Australia. Int. J. Syst. Bacteriol. 1996, 46, 265-269. [CrossRef]

83. Kanoksilapatham, W.; Pasomsup, P.; Keawram, P.; Cuecas, A.; Portillo, M.C.; Gonzalez, J.M. Fervidobacterium thailandense Sp. Nov., an Extremely Thermophilic Bacterium Isolated from a Hot Spring. Int. J. Syst. Evol. Microbiol. 2016, 66, 5023-5027. [CrossRef]

84. Cai, J.; Wang, Y.; Liu, D.; Zeng, Y.; Xue, Y.; Ma, Y.; Feng, Y. Fervidobacterium changbaicum Sp. Nov., a Novel Thermophilic Anaerobic Bacterium Isolated from a Hot Spring of the Changbai Mountains, China. Int. J. Syst. Evol. Microbiol. 2007, 57, 2333-2336. [CrossRef]

85. Huber, R.; Woese, C.R.; Langworthy, T.A.; Fricke, H.; Stetter, K.O. Thermosipho Africanus Gen. Nov., Represents a New Genus of Thermophilic Eubacteria within the "Thermotogales". Syst. Appl. Microbiol. 1989, 12, 32-37. [CrossRef]

86. Takai, K.; Horikoshi, K. Thermosipho japonicus Sp. Nov., an Extremely Thermophilic Bacterium Isolated from a Deep-Sea Hydrothermal Vent in Japan. Extremophiles 2000, 4, 9-17. [CrossRef]

87. L'Haridon, S.; Miroshnichenko, M.L.; Hippe, H.; Fardeau, M.L.; Bonch-Osmolovskaya, E.; Stackebrandt, E.; Jeanthon, C. Thermosipho geolei Sp. Nov., a Thermophilic Bacterium Isolated from a Continental Petroleum Reservoir in Western Siberia. Int. J. Syst. Evol. Microbiol. 2001, 51, 1327-1334. [CrossRef] [PubMed]

88. Podosokorskaya, O.A.; Kublanov, I.V.; Reysenbach, A.L.; Kolganova, T.V.; Bonch-Osmolovskaya, E.A. Thermosipho affectus Sp. Nov., a Thermophilic, Anaerobic, Cellulolytic Bacterium Isolated from a Mid-Atlantic Ridge Hydrothermal Vent. Int. J. Syst. Evol. Microbiol. 2011, 61, 1160-1164. [CrossRef] [PubMed]

89. Kuwabara, T.; Kawasaki, A.; Uda, I.; Sugai, A. Thermosipho globiformans Sp. Nov., an Anaerobic Thermophilic Bacterium That Transforms into Multicellular Spheroids with a Defect in Peptidoglycan Formation. Int. J. Syst. Evol. Microbiol. 2011, 61, $1622-1627$. [CrossRef] [PubMed]

90. Antoine, E.; Cilia, V.; Meunier, J.R.; Guezennec, J.; Lesongeur, F.; Barbier, G. Thermosipho melanesiensis Sp. Nov., a New Thermophilic Anaerobic Bacterium Belonging to the Order Thermotogales, Isolated from Deep-Sea Hydrothermal Vents in the Southwestern Pacific Ocean. Int. J. Syst. Bacteriol. 1997, 47, 1118-1123. [CrossRef] [PubMed]

91. Podosokorskaya, O.A.; Bonch-Osmolovskaya, E.A.; Godfroy, A.; Gavrilov, S.N.; Beskorovaynaya, D.A.; Sokolova, T.G.; Kolganova, T.V.; Toshchakov, S.V.; Kublanov, I.V. Thermosipho activus Sp. Nov., a Thermophilic, Anaerobic, Hydrolytic Bacterium Isolated from a Deep-Sea Sample. Int. J. Syst. Evol. Microbiol. 2014, 64, 3307-3313. [CrossRef] [PubMed]

92. Urios, L.; Cueff-Gauchard, V.; Pignet, P.; Postec, A.; Fardeau, M.L.; Ollivier, B.; Barbier, G. Thermosipho atlanticus Sp. Nov., a Novel Member of the Thermotogales Isolated from a Mid-Atlantic Ridge Hydrothermal Vent. Int. J. Syst. Evol. Microbiol. 2004, 54, 1953-1957. [CrossRef]

93. L'Haridon, S.; Miroshnichenko, M.L.; Hippe, H.; Fardeau, M.L.; Stackebrandt, E.; Jeanthon, C. Petrotoga olearia Sp. Nov. and Petrotoga sibirica Sp. Nov., Two Thermophilic Bacteria Isolated from a Continental Petroleum Reservoir in Western Siberia. Int. J. Syst. Evol. Microbiol. 2002, 52, 1715-1722. [CrossRef]

94. Lien, T.; Madsen, M.; Rainey, F.A.; Birkeland, N.K. Petrotoga mobilis Sp. Nov., from a North Sea Oil-Production Well. Int. J. Syst. Bacteriol. 1998, 48, 1007-1013. [CrossRef]

95. Miranda-Tello, E.; Fardeau, M.L.; Joulian, C.; Magot, M.; Thomas, P.; Tholozan, J.L.; Olivier, B. Petrotoga halophila Sp. Nov., a Thermophilic, Moderately Halophilic, Fermentative Bacterium Isolated from an Offshore Oil Well in Congo. Int. J. Syst. Evol. Microbiol. 2007, 57, 40-44. [CrossRef]

96. Miranda-Tello, E.; Fardeau, M.L.; Thomas, P.; Ramirez, F.; Casalot, L.; Cayol, J.L.; Garcia, J.L.; Ollivier, B. Petrotoga mexicana Sp. Nov., a Novel Thermophilic, Anaerobic and Xylanolytic Bacterium Isolated from an Oil-Producing Well in the Gulf of Mexico. Int. J. Syst. Evol. Microbiol. 2004, 54, 169-174. [CrossRef]

97. Purwasena, I.A.; Sugai, Y.; Sasaki, K. Petrotoga japonica Sp. Nov., a Thermophilic, Fermentative Bacterium Isolated from Yabase Oilfield in Japan. Arch Microbiol. 2014, 196, 313-321. [CrossRef] [PubMed]

98. Alain, K.; Marteinsson, V.T.; Miroshnichenko, M.L.; Bonch-Osmolovskaya, E.A.; Prieur, D.; Birrien, J.-L. Marinitoga piezophila Sp Nov., a Rod-Shaped, Thermo-Piezophilic Bacterium Isolated under High Hydrostatic Pressure from a Deep-Sea Hydrothermal Vent. Int. J. Syst. Evol. Microbiol. 2002, 52, 1331-1339. [CrossRef] [PubMed]

99. Postec, A.; Ciobanu, M.; Birrien, J.L.; Bienvenu, N.; Prieur, D.; Le Romancer, M. Marinitoga litoralis Sp. Nov., a Thermophilic, Heterotrophic Bacterium Isolated from a Coastal Thermal Spring on Île Saint-Paul, Southern Indian Ocean. Int. J. Syst. Evol. Microbiol. 2010, 60, 1778-1782. [CrossRef] [PubMed]

100. Nunoura, T.; Oida, H.; Miyazaki, M.; Suzuki, Y.; Takai, K.; Horikoshi, K. Marinitoga okinawensis Sp. Nov., a Novel Thermophilic and Anaerobic Heterotroph Isolated from a Deep-Sea Hydrothermal Field, Southern Okinawa Trough. Int. J. Syst. Evol. Microbiol. 2007, 57, 467-471. [CrossRef] [PubMed] 
101. Postec, A.; Le Breton, C.; Fardeau, M.L.; Lesongeur, F.; Pignet, P.; Querellou, J.; Ollivier, B.; Godfroy, A. Marinitoga hydrogenitolerans Sp. Nov., a Novel Member of the Order Thermotogales Isolated from a Black Smoker Chimney on the Mid-Atlantic Ridge. Int. J. Syst. Evol. Microbiol. 2005, 55, 1217-1221. [CrossRef] [PubMed]

102. Steinsbu, B.O.; Røyseth, V.; Thorseth, I.H.; Steen, I.H. Marinitoga arctica Sp. Nov., a Thermophilic, Anaerobic Heterotroph Isolated from a Mid-Ocean Ridge Vent Field. Int. J. Syst. Evol. Microbiol. 2016, 66, 5070-5076. [CrossRef]

103. Nunoura, T.; Hirai, M.; Imachi, H.; Miyazaki, M.; Makita, H.; Hirayama, H.; Furushima, Y.; Yamamoto, H.; Takai, K. Kosmotoga arenicorallina Sp. Nov. a Thermophilic and Obligately Anaerobic Heterotroph Isolated from a Shallow Hydrothermal System Occurring within a Coral Reef, Southern Part of the Yaeyama Archipelago, Japan, Reclassification of Thermococcoides shengliensis. Arch. Microbiol. 2010, 192, 811-819. [CrossRef] [PubMed]

104. L'Haridon, S.; Jiang, L.; Alain, K.; Chalopin, M.; Rouxel, O.; Beauverger, M.; Xu, H.; Shao, Z.; Jebbar, M. Kosmotoga pacifica Sp. Nov., a Thermophilic Chemoorganoheterotrophic Bacterium Isolated from an East Pacific Hydrothermal Sediment. Extremophiles 2014, 18, 81-88. [CrossRef]

105. Van Ooteghem, S.A.; Beer, S.K.; Yue, P.C. Hydrogen Production by the Thermophilic Bacterium Thermotoga neapolitana. Appl. Biochem. Biotechnol. 2002, 98-100, 177-189. [CrossRef]

106. Eriksen, N.T.; Nielsen, T.M.; Iversen, N. Hydrogen Production in Anaerobic and Microaerobic Thermotoga neapolitana. Biotechnol. Lett. 2008, 30, 103-109. [CrossRef]

107. Boileau, C.; Auria, R.; Davidson, S.; Casalot, L.; Christen, P.; Liebgott, P.P.; Combet-Blanc, Y. Hydrogen Production by the Hyperthermophilic Bacterium Thermotoga maritima Part I: Effects of Sulfured Nutriments, with Thiosulfate as Model, on Hydrogen Production and Growth. Biotechnol. Biofuels 2016, 9, 1-17. [CrossRef] [PubMed]

108. Van Niel, E.W.J.; Budde, M.A.W.; De Haas, G.; van der Wal, F.J.; Claassen, P.A.M.; Stams, A.J.M. Distinctive Properties of High Hydrogen Producing Extreme Thermophiles, Caldicellulosiruptor saccharolyticus and Thermotoga elfii. Int. J. Hydrogen Energy 2002, 27, 1391-1398. [CrossRef]

109. Hawkes, F.; Hussy, I.; Kyazze, G.; Dinsdale, R.; Hawkes, D. Continuous Dark Fermentative Hydrogen Production by Mesophilic Microflora: Principles and Progress. Int. J. Hydrogen Energy 2007, 32, 172-184. [CrossRef]

110. Nguyen, T.A.D.; Han, S.J.; Kim, J.P.; Kim, M.S.; Sim, S.J. Hydrogen Production of the Hyperthermophilic Eubacterium, Thermotoga neapolitana under $\mathrm{N}_{2}$ Sparging Condition. Bioresour. Technol. 2010, 101, S38-S41. [CrossRef]

111. Karadagli, F.; Marcus, A.K.; Rittmann, B.E. Role of Hydrogen (H2) Mass Transfer in Microbiological H2-Threshold Studies. Biodegradation 2019, 30, 113-125. [CrossRef]

112. Nath, K.; Das, D. Improvement of Fermentative Hydrogen Production: Various Approaches. Appl. Microbiol. Biotechnol. 2004, 65, 520-529. [CrossRef]

113. Ngo, T.A.; Mi-sun, K.; Sim, S.J. Thermophilic Hydrogen Fermentation Using Thermotoga neapolitana DSM 4359 by Fed-Batch Culture. Int. J. Hydrogen Energy 2011, 36, 14014-14023. [CrossRef]

114. Pradhan, N.; Dipasquale, L.; d’Ippolito, G.; Fontana, A.; Panico, A.; Lens, P.N.L.; Pirozzi, F.; Esposito, G. Kinetic modeling of fermentative hydrogen production by Thermotoga neapolitana. Int. J. Hydrogen Energy 2016, 41, 1-10. [CrossRef]

115. Mizuno, O.; Dinsdale, R.; Hawkes, F.R.; Hawkes, D.L. Enhancement of Hydrogen Production from Glucose by Nitrogen Gas Sparging. Bioresour. Technol. 2000, 73, 59-65. [CrossRef]

116. Ngo, T.A.; Kim, M.S.; Sim, S.J. High-Yield Biohydrogen Production from Biodiesel Manufacturing Waste by Thermotoga neapolitana. Int. J. Hydrogen Energy 2011, 36, 5836-5842. [CrossRef]

117. D'Ippolito, G.; Dipasquale, L.; Fontana, A. Recycling of Carbon Dioxide and Acetate as Lactic Acid by the Hydrogen-Producing Bacterium Thermotoga neapolitana. ChemSuschem 2014, 7, 2678-2683. [CrossRef] [PubMed]

118. Pradhan, N.; Dipasquale, L.; d'Ippolito, G.; Fontana, A.; Panico, A.; Pirozzi, F.; Lens, P.N.L.; Esposito, G. Model Development and Experimental Validation of Capnophilic Lactic Fermentation and Hydrogen Synthesis by Thermotoga neapolitana. Water Res. 2016, 99, 225-234. [CrossRef] [PubMed]

119. Dipasquale, L.; Adessi, A.; d'Ippolito, G.; Rossi, F.; Fontana, A.; De Philippis, R. Introducing Capnophilic Lactic Fermentation in a Combined Dark-Photo Fermentation Process: A Route to Unparalleled $\mathrm{H}_{2}$ Yields. Appl. Microbiol. Biotechnol. 2015, 99, 1001-1010. [CrossRef] [PubMed]

120. D’Ippolito, G.; Landi, S.; Esercizio, N.; Lanzilli, M.; Vastano, M.; Dipasquale, L.; Pradhan, N.; Fontana, A. CO 2 -Induced Transcriptional Reorganization: Molecular Basis of Capnophillic Lactic Fermentation in Thermotoga neapolitana. Front. Microbiol. 2020, 11, 171. [CrossRef] [PubMed]

121. Van Ooteghem, S.A.; Jones, A.; Van Der Lelie, D.; Dong, B.; Mahajan, D. $\mathrm{H}_{2}$ Production and Carbon Utilization by Thermotoga neapolitana under Anaerobic and Microaerobic Growth Conditions. Biotechnol. Lett. 2004, 26, 1223-1232. [CrossRef] [PubMed]

122. Ngo, T.A.; Sim, S.J. Dark Fermentation of Hydrogen from Waste Glycerol Using Hyperthermophilic Eubacterium Thermotoga neapolitana. Environ. Prog. Sustain. Energy 2011, 31, 466-473. [CrossRef]

123. Juszczak, A.; Aono, S.; Adams, M.W.W. The Extremely Thermophilic Eubacterium, Thermotoga maritima Contains a Novel Iron-Hydrogenase Whose Cellular Activity Is Dependent Upon Tungsten. J. Bacteriol. Chem. 1991, 226, 13834-13841. [PubMed]

124. Rusch, A.; Walpersdorf, E.; DeBeer, D.; Gurrier, S.; Amend, P.J. Microbial Communities near the Oxic/Anoxic Interface in the Hydrothermal System of Vulcano Island, Italy. Chem. Geol. 2005, 224, 169-182. [CrossRef]

125. Belkin, S.; Wirsen, C.O.; Jannasch, H.W. A New Sulfur-Reducing, Extremely Thermophilic Eubacterium from a Submarine Thermal Vent. Appl. Environ. Microbiol. 1986, 51, 1180-1185. [CrossRef] 
126. Childers, S.E.; Vargas, M.; Noll, K.M. Improved Methods for Cultivation of the Extremely Thermophilic Bacterium Thermotoga neapolitana. Appl. Environ. Microbiol. 1992, 58, 3949-3953. [CrossRef]

127. Le Fourn, C.; Fardeau, M.L.; Ollivier, B.; Lojou, E.; Dolla, A. The Hyperthermophilic Anaerobe Thermotoga maritima Is Able to Cope with Limited Amount of Oxygen: Insights into Its Defence Strategies. Environ. Microbiol. 2008, 10, 1877-1887. [CrossRef] [PubMed]

128. Tosatto, S.C.E.; Toppo, S.; Carbonera, D.; Giacometti, G.M.; Costantini, P. Comparative Analysis of [FeFe] Hydrogenase from Thermotogales Indicates the Molecular Basis of Resistance to Oxygen Inactivation. Int. J. Hydrogen Energy 2008, 33, 570-578. [CrossRef]

129. Lakhal, R.; Auria, R.; Davidson, S.; Ollivier, B.; Dolla, A.; Hamdi, M.; Combet-Blanc, Y. Effect of Oxygen and Redox Potential on Glucose Fermentation in Thermotoga maritima under Controlled Physicochemical Conditions. Int. J. Microbiol. 2010, 2010, 896510. [CrossRef] [PubMed]

130. Kaslin, S.A.; Childers, S.E.; Noll, K.M. Membrane-Associated Redox Activities in Thermotoga neapolitana. Arch. Microbiol. 1998, 170, 297-303. [CrossRef] [PubMed]

131. Yang, X.; Ma, K. Purification and Characterization of an NADH Oxidase from Extremely Thermophilic Anaerobic Bacterium Thermotoga hypogea. Arch. Microbiol. 2005, 183, 331-337. [CrossRef] [PubMed]

132. Yang, X.; Ma, K. Characterization of an Exceedingly Active NADH Oxidase from the Anaerobic Hyperthermophilic Bacterium Thermotoga maritima. J. Bacteriol. 2007, 189, 3312-3317. [CrossRef]

133. Mangayil, R.; Aho, T.; Karp, M.; Santala, V. Improved Bioconversion of Crude Glycerol to Hydrogen by Statistical Optimization of Media Components. Renew. Energy 2015, 75, 583-589. [CrossRef]

134. Abdullah, M.F.; Md Jahim, J.; Abdul, P.M.; Mahmod, S.S. Effect of Carbon/Nitrogen Ratio and Ferric Ion on the Production of Biohydrogen from Palm Oil Mill Effluent (POME). Biocatal. Agric. Biotechnol. 2020, 23, 101445. [CrossRef]

135. Munro, S.A.; Choe, L.; Zinder, S.H.; Lee, K.H.; Walker, L.P. Proteomic and Physiological Experiments to Test Thermotoga neapolitana Constraint-Based Model Hypotheses of Carbon Source Utilization. Biotechnol. Prog. 2012, 28, 312-318. [CrossRef]

136. Rinker, K.D.; Kelly, R.M. Effect of Carbon and Nitrogen Sources on Growth Dynamics and Exopolysaccharide Production for the Hyperthermophilic Archaeon Thermococcus Litoralis and Bacterium Thermotoga maritima. Biotechnol. Bioeng. 2000, 69, 537-547. [CrossRef]

137. Van Niel, E.W.J.; Hahn-Hägerdal, B. Nutrient Requirements of Lactococci in Defined Growth Media. Appl. Microbiol. Biotechnol. 1999, 52, 617-627. [CrossRef]

138. Maru, B.T.; Bielen, A.A.M.; Kengen, S.W.M.; Constantí, M.; Medinaa, F. Biohydrogen Production from Glycerol Using Thermotoga Spp. Energy Procedia 2012, 29, 300-307. [CrossRef]

139. Kengen, S.W.M.; Stams, A.J.M. Formation of L-Alanine as a Reduced End Product in Carbohydrate Fermentation by the Hyperthermophilic Archaeon Pyrococcus Furiosus. Arch. Microbiol. 1994, 161, 168-175. [CrossRef]

140. Weiner, R.; Langille, S.; Quintero, E. Structure, Function, and Immu- Nochemistry of Bacterial Exopolysaccharides. J. Ind. Microbiol. 1995, 15, 339-346. [CrossRef] [PubMed]

141. Pierra, M.; Trably, E.; Godon, J.J.; Bernet, N. Fermentative Hydrogen Production under Moderate Halophilic Conditions. Int. J. Hydrogen Energy 2014, 39, 7508-7517. [CrossRef]

142. Liu, Q.; Chen, W.; Zhang, X.; Yu, L.; Zhou, J.; Xu, Y.; Qian, G. Phosphate Enhancing Fermentative Hydrogen Production from Substrate with Municipal Solid Waste Composting Leachate as a Nutrient. Bioresour. Technol. 2015, 190, 431-437. [CrossRef] [PubMed]

143. Chang, F.; Lin, C. Calcium Effect on Fermentative Hydrogen Production in an Anaerobic Up-Flow Sludge Blanket System. Water Sci. Technol. 2006, 54, 105-112. [CrossRef]

144. Ravot, G.; Ollivier, B.; Magot, M.; Patel, B.K.C.; Crolet, J.L.; Fardeau, M.L.; Garcia, J.L. Thiosulfate Reduction, an Important Physiological Feature Shared by Members of the Order Thermotogales. Appl. Environ. Microbiol. 1995, 61, 2053-2055. [CrossRef]

145. Ravot, G.; Ollivier, B.; Fardeau, M.L.; Patel, B.K.C.; Andrews, K.T.; Magot, M.; Garcia, J.L. L-Alanine Production from Glucose Fermentation by Hyperthermophilic Members of the Domains Bacteria and Archaea: A Remnant of an Ancestral Metabolism? Appl. Environ. Microbiol. 1996, 62, 2657-2659. [CrossRef]

146. Ainala, S.K.; Seol, E.; Kim, J.R.; Park, S. Effect of Culture Medium on Fermentative and CO-Dependent $\mathrm{H}_{2}$ Production Activity in Citrobacter Amalonaticus Y19. Int. J. Hydrogen Energy 2016, 41, 6734-6742. [CrossRef]

147. Huber, R.; Stetter, K.O. The Order Thermotogales. In The Prokaryotes; Springer: New York, NY, USA, $1992 ;$ pp. $93809-93815$.

148. Hania, W.B.; Fadhlaoui, K.; Brochier-Armanet, C.; Persillon, C.; Postec, A.; Hamdi, M.; Dolla, A.; Ollivier, B.; Fardeau, M.L.; Le Mer, J.; et al. Draft Genome Sequence of Mesotoga Strain PhosAC3, a Mesophilic Member of the Bacterial Order Thermotogales, Isolated from a Digestor Treating Phosphogypsum in Tunisia. Stand. Genom. Sci. 2015, 10, 1-7. [CrossRef] [PubMed]

149. Nesbø, C.L.; Charchuk, R.; Pollo, S.M.J.; Budwill, K.; Kublanov, I.V.; Haverkamp, T.H.A.; Foght, J. Genomic Analysis of the Mesophilic Thermotogae Genus Mesotoga Reveals Phylogeographic Structure and Genomic Determinants of Its Distinct Metabolism. Environ. Microbiol. 2019, 21, 456-470. [CrossRef] [PubMed]

150. Tao, Z.; Yang, Q.; Yao, F.; Huang, X.; Wu, Y.; Du, M.; Chen, S.; Liu, X.; Li, X.; Wang, D. The Inhibitory Effect of Thiosulfinate on Volatile Fatty Acid and Hydrogen Production from Anaerobic Co-Fermentation of Food Waste and Waste Activated Sludge. Bioresour. Technol. 2020, 297, 122428. [CrossRef] [PubMed]

151. Slobodkin, A.I. Thermophilic Microbial Metal Reduction. Microbiologia 2005, 74, 581-595. [CrossRef] 
152. Gomez-Romero, J.; Gonzalez-Garcia, A.; Chairez, I.; Torres, L.; García-Peña, E.I. Selective Adaptation of an Anaerobic Microbial Community: Biohydrogen Production by Co-Digestion of Cheese Whey and Vegetables Fruit Waste. Int. J. Hydrogen Energy 2014, 39, 12541-12550. [CrossRef]

153. Llanos, J.; Capasso, C.; Parisi, E.; Prieur, D.; Jeanthon, C. Susceptibility to Heavy Metals and Cadmium Accumulation in Aerobic and Anaerobic Thermophilic Microorganisms Isolated from Deep-Sea Hydrothermal Vents. Curr. Microbiol. 2000, 41, $0201-0205$. [CrossRef]

154. Vargas, M.; Kashefi, K.; Blunt-harris, E.L.; Lovley, D.R. Fe (III) Reduction on Early Earth. Nature 1998, 395, 65-67. [CrossRef]

155. Balch, W.E.; Fox, G.E.; Magrum, L.J.; Woese, C.R.; Wolfe, R.S. Methanogens: Reevaluation of a Unique Biological Group. Microbiol. Rev. 1979, 43, 260-296. [CrossRef]

156. Lee, Y.J.; Miyahara, T.; Noike, T. Effect of Iron Concentration on Hydrogen Fermentation. Bioresour. Technol. 2001, 80, $227-231$. [CrossRef]

157. Zhang, Y.; Shen, J. Effect of Temperature and Iron Concentration on the Growth and Hydrogen Production of Mixed Bacteria. Int. J. Hydrogen Energy 2006, 31, 441-446. [CrossRef]

158. Ying, X.; Wang, Y.; Badiei, H.R.; Karanassios, V.; Ma, K. Purification and Characterization of an Iron-Containing Alcohol Dehydrogenase in Extremely Thermophilic Bacterium Thermotoga hypogea. Arch. Microbiol. 2007, 187, 499-510. [CrossRef] [PubMed]

159. Trivedi, S.; Rao, S.R.; Gehlot, H.S. Nucleic Acid Stability in Thermophilic Prokaryotes: A Review Nucleic Acid Stability in Thermophilic Prokaryotes: A Review. J. Cell Mol. Biol. 2005, 4, 61-69. 